\title{
FINAL \55UE
}

\section{AFEHANLSTAN}

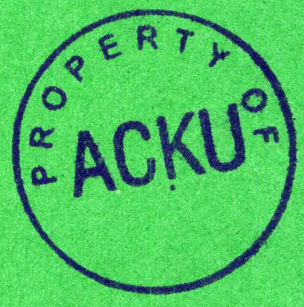

FORUM

\section{EONTENTS}

VDL. $\times \times 8$

winter

1997

ND. 4

Recent Publications........................ 1

Newsletters \& Websites...................... 2

Chronology .............................. $3-8$

News Items $\ldots \ldots \ldots \ldots \ldots \ldots \ldots \ldots \ldots \ldots \ldots \ldots \ldots \ldots \ldots . \ldots \ldots . \ldots \ldots$

Women's issues........................ 16-19

Opium Production........................ 24-25

Iran's role.......................... 26-28

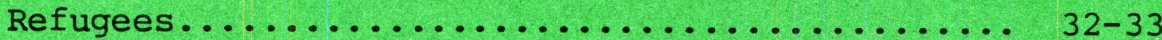

People............................. $34-35$

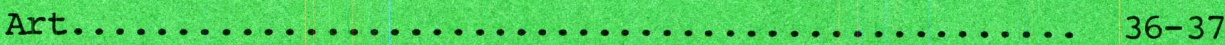

Book Reviews......................... 38-41, 15

Tribute to Leon Poullada................. 42

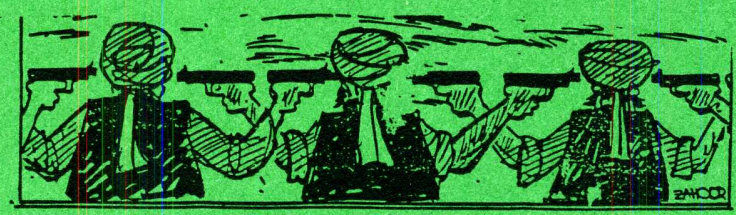

THE AFGHANISTAN FORUM, INC.

19 Fanning Avenue East Hampton, NY 11937 


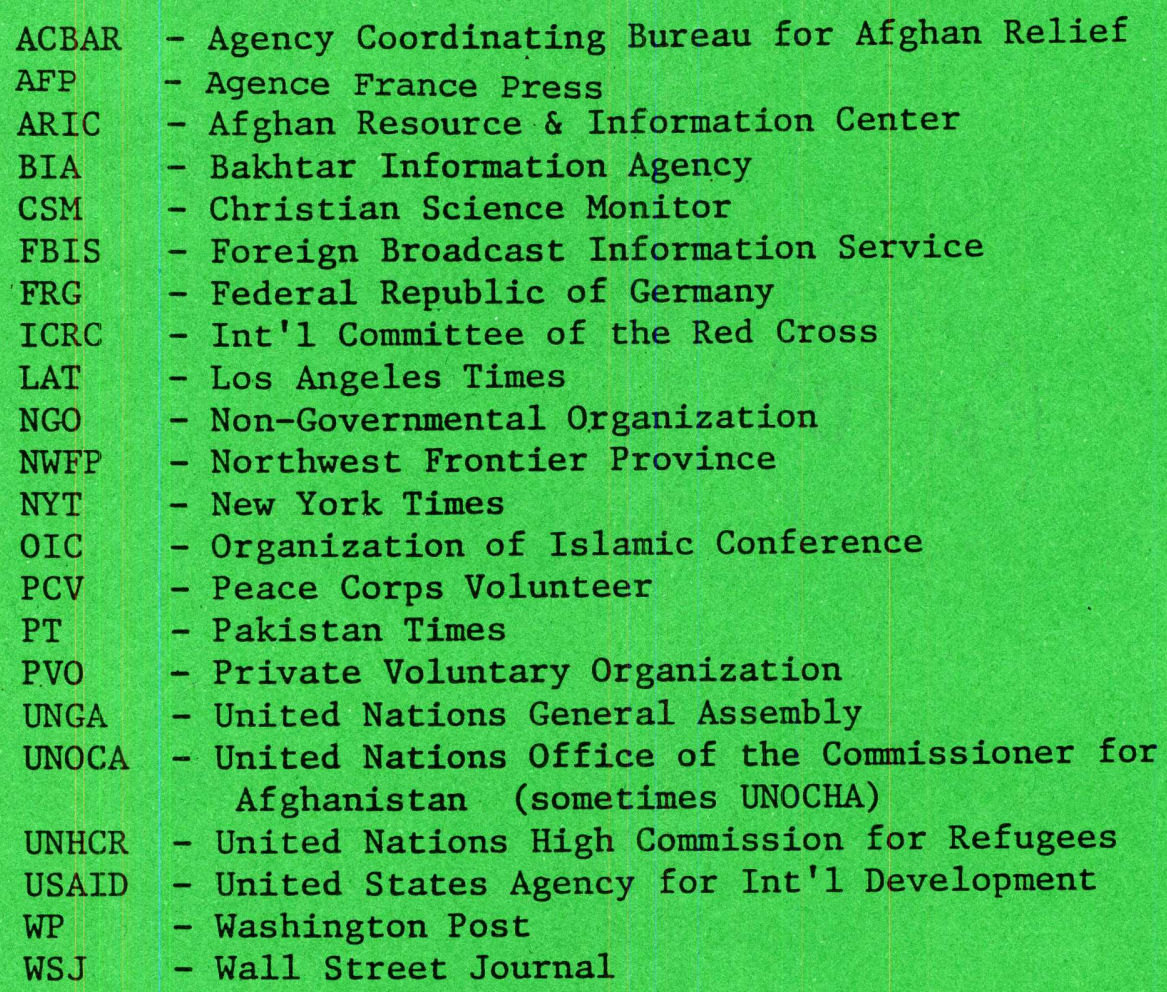

The opinions expressed in the FORUM are those of the parties \& publications involved \& are not necessarily those of the Afghanistan FORUM. Listing of organizations does not necessarily imply endorsement.

Mary Ann Siegfried Editor \& Typist
Leonard Oppenheim

Treasurer \& Proofreader

Book Review Editors

Rosanne Klass

Rhea Talley Stewart 
From the Editor:

What can we tell you! We kept putting it off. We knew you'd know the last issue would come out eventually. And here it is.

Thanks to all of you who wrote us such nice things about the FORUM. We shall miss doing it \& expecially miss hearing from all of you.

On page 2 we have listed some other sources of print information on Afghanistan as well as some wild \& wonderful websites. If things keep going the way they are in Afghanistan, perhaps you can just reread an old FORUM once in a while, changing a few names, of course. We shall issue one more Occasional Paper: "A Short History of an Era 1869-1881: The Reminiscences of Mahmud Tarzi," translated \& edited by Wahid Tarzi. We'll hope to have it out by early February. If you didn't include the paper price in your subscription \& you want a copy, send us a check for $\$ 5$ before February 1 .

Finally, thanks to all of you who have helped us make the FORUM what it's been. As with what was once Afghanistan, we may not see its like again.

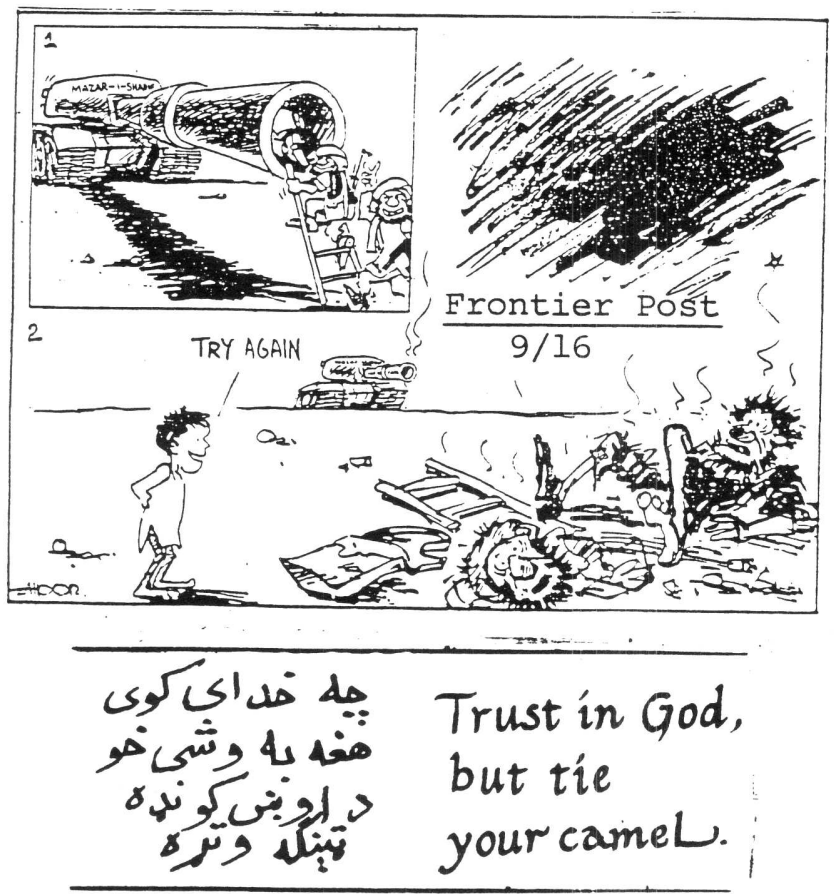

RELENT PUBLIEATIONS

CENTRAL ASIA: FOUNDATION OF CHANGE by R.D. McChesney. Darwin Press, Princeton, NJ, 1997. 26 color plates, 204 pp., index, notes, 4 maps. $\$ 35$. This book is based on the 1993 Poullada lecture series.

HISTORICAL DICTIONARY OF AFGHANISTAN, 2nd Edition by Ludwig W. Adamec (Asian/Oceanian Historical Dictionaries \#5). Scarecrow Press, Lanham, MD \& London, 1997. 500 pp. \$58. (Scarecrow Press, 4720 Boston Way, Lanham, MD 20706) ISBN 0-8108-3312-3. (See short review on p. 15 )

THE AFGHANISTAN STUDIES JOURNAL, Vol. 5, 1997, published at the University of Nebraska, P.O. Box 3588, Omaha, NE 681039960, has the theme of "The Halcyon Days of Afghanistan." $\$ 10$.

AFGHANISTAN: MULLAH, MARX, MUJAHID by Eden Naby \& Ralph Magnus has been published by Westview Press. The 274 page book has a foreward by Dan Rather. ISBN 8-86531-513-2.

From CENTRAL ASIAN SURVEY, Vol. 16, \#3, September 1997: "The Hazaras \& their role in the process of political transformation in Afghanistan" by Hafizullah Emadi. Pp. 363-88; "Development of family law in Afghanistan: the roles of the Hanafi Madhab, customary practices \& power politics" by Helena Malikyar. Pp 389-399.

FUNDAMENTALISM REBORN? AFGHANISTAN UNDER THE TALIBAN edited by William Maley, london, C. Hurst \& Co., 1997. 288 pp.

THE HAZARAS OF AFGHANISTAN, AN HISTORICAL, CUETURAL, ECONOMIC \& POLITICAL STUDY bY Sayed Askar Mousavi, Richmond, Curzon Press Ltd., 1997. 288 pp.

From Sweden: RESA TILL AFGHANISTAN by Paul Mohn. $289 \mathrm{pp}$, richly illustrated with photographs from the period 1883-1928. AFGHANISTAN FORR OCH NU, the Swedish Afghanistan Committee's handbook on Afghanistan. $320 \mathrm{pp} .$, illustrated. Has information on Afghanistan's history, literature, nature, architecture, etc. 


\section{Taking In the Sites}

FRIENDS OF AFGHANISTAN quarterly newsletter, edited by Susan Aronson, 9025 Chantal Way, Sacramento, CA 95829-1717. Published in March, June, September \& December; \$15/year. Make checks payable to Friends of Afghanistan.

\section{AFGHAN COMMUNICATOR}

oAfghanistan Peace Association P.O. Box 926, P.O. Box 926, Flushing, NY 11354. \$15/year will bring you this "Voice of the Young Generation." Rameen Moshref is Editor-in-Chief. Make checks payable to Afghan Communicator.

AFGHANISTAN INFO, edited by Micheline Centlivres-Demont, 24, av.de la Gare, 2000 Neuchatel, Switzerland has articles in French, German \&, occasionally, English. Write Ms. Centlivres for subscription information.

LES NOUVELLES D'AFGHANISTAN, BP 254, 75524 Paris Cedex 11, France, is edited by Etienne Gille, is a quarterly in French. US subscriptions are $150 \mathrm{FF} /$ year.

AFGHANISTAN NYT'T published by the Swedish Committee for Afghanistan is edited by Peter Hjukstrom. Available from the Svenska Afghanistankommitten, Sturegatan 16, 11436 Stockholm, Sweden, a year's subscription is 200 kroner. (In Swedish).

SPACH NEWSLETTER, the organ of the Society for the Preservation of Afghanistan's Cultural Heritage, is edited by Brigitte Neubacher, POB 1809, Islamabad, Pakistan. Membership in SPACH is $\$ 50 /$ year \& checks can be sent to SPACH, \%UNOCHA, $16 \mathrm{Av}$. Jean Trembley, Petit Saconnex, CH-12ll Geneva 10, Switzerland. (For info on SPACH, see p. 37 .)

AFGHANISTAN VOICE, a monthly publication of the Association for Peace \& Democracy for Afghanistan, (5603 Sheldon Drive, Alexandria, VA 22312). The VOICE's Editor is Qasem Ghazanfar. Subscriptions are \$10/year from Afghanistan Voice, P.O. Box 104, Bloomingdale, NJ 07403.

MUSLIM WORLD MONITOR, \%I.A.P. Information Office, P.O. Box 74805, Dallas TX 75374-1805. Biweekly, \$25/yr. Make checks payable to Islamic Assn. for Palestine.
Friends of Afghanistan: http://www.royalpages.com/rfoa/

Sabawoon Online: http: //www.'sabawoon.com

Afghanistan Online Press www. afghan-web.com/www.html

Afghan Cultural Information Center: www.gl.umbc . edu/- hqurbal/Afghanistan

Afghan Embassy on the Internet: htmi. http://www . afghan-government.com.

United Nations Weekly Update on Afghanistan: unocha@unocha.sdnpk . undp.org

UN Dept. on Humanitarian Affairs: www.reliefweb.int

\section{Islamic sites encourage global solidarity among Muslims.}

By far the most extensive site is I Islamic Gateway, which is based in London and pumps the Internet with opinions and information about Muslim political and religious issues, dispatching them daily on its growing Momin-Net mailing list of about 15,000. And despite its motto of restoring the fun to fundamentalism, the site brims with anger and an overarching desire to create solidarity among Muslims worldwide.

The two-year-old site.acts as an open forum on topics ranging from Kashmiri Muslims' effort to achieve independence from India to the views of the fiercely militant Taliban movement of Afghanistan and those of a Saudi dissident, Osama bin Laden. Mr. bin Laden, a multimillionaire scion of a wealthy Saudi merchant family, was stripped of his Saudi citizenship in 1994 and is based in Afghanistan.

\section{WHERE TO GO}

ISLAMIC GATEWAY http://ummah.org.uk

DATING SERVICE FOR MUSLIM MEN AND WOMEN http://www.academic.marist.edu/hayman/muslim.htm

- INFORMATION AND SUGGESTIONS OF MUSLIM NAMES http://www.uidaho.edu/ yusuf921/names.html ITYT $10 / 13$
CYBERMUSLIM INFORMATION COLLECTIVE http://www.uoknor.edu/cybermuslim/cybermuslim.html
New York Times: www. nytimes.com

CEREDAF (France) Ourworld. Compuserv com/homepages/ Afghanistan_Franc

Frontier Post: www pakcyber. com frontier-post/

For on-line shopping http://www. afghan shop.com

(food, music, vide \& books.)

SPACH NEWSLETTER:

http: / / www.col.com pk/clients/afghan, news.htm whose motto is, "We Gateway FUN back into fundamentalism"

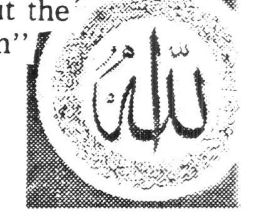


8/15 - Afghan News Service - Lakhdar Brahimi, the UN Sec'y Gen'l's Special Envoy to Afghanistan, arrived in Islamabad to assess UN peace-making activities in Afghanistan (see p 10 ).

$8 / 25$ - Agence France Presse - Hundreds of people attended the burial ceremony for Abdul Rahim Ghafoorzai, held in the blue mosque in Mazar last Saturday. He was killed Thursday in a plane crash in Bamiyan. Aziz Murrad, a Rabbani spokesman, was also killed in the crash.

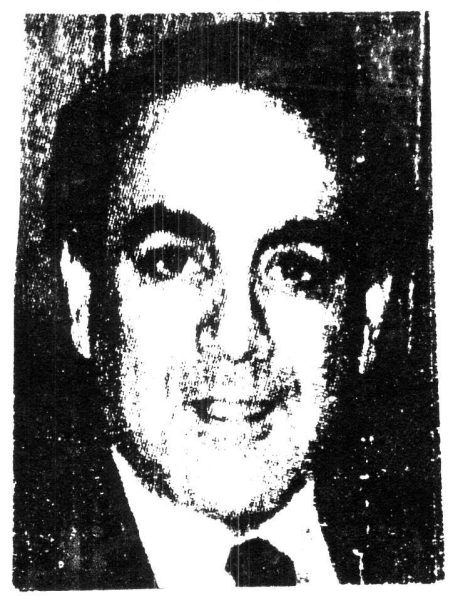

8/26 - AP - Taliban raided a minority neighborhood in Kabul \& rounded up over 100 people whom they accused of gambling \& smoking hashish. Police chief Abdul Razak said, "We found cassettes \& photographs of Massoud in our searches."

$8 / 31$ - News (Pakistan) Iranian President Moh'd Khatami has appointed Alaeddin Boroujerdi as Iran's special envoy to Afghanistan.

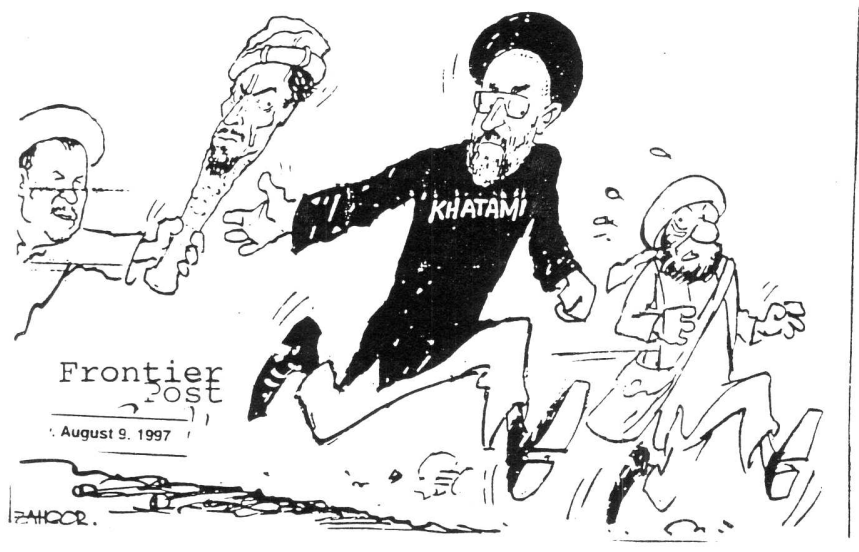

9/1 - AP - Massood \& Khalili refused to hold separate negotiations with Taliban. Taliban had offered to talk if Malik Pahlawan would release the 3,000 prisoners he reportedly has held since the Taliban retreat from Mazar last May.

9/2 - Reuters - Saudi Arabian King Fahd received Taliban Mullah Moh'd Rabbani in Jeddah. Saudi Arabia recognized the Taliban gov't in May. Rabbani was accompanied by Planning Minister gari Mir Moh'd, Communications Minister Mullah
Allah Dad Zahidi \& Foreign Sec'y Moh'd Stanakzai.

9/5 - Afghan online Press says that Taliban support the idea of holding a meeting of Afghan leaders in Saudi Arabia to work for a peaceful settlement. Lakhdar Brahimi, the UN Special Envoy, received similar support for the idea from the Northern Alliance (in Mazar), Hekmatyar (in Tehran) \& Taliban (in Kandahar).

- Dawn (Pakistan) - The Chief Minister of Baluchistan advised all Afghan nationals to return home \& not be "a continued burden on the meager resources of this country,"

9/7 -Afghan online Press reports that Taliban has called for an immediate start on the proposed Afghan-Pak-Turkmen gas pipeline. The 48" pipeline would go through Torghundi, Herat, Lashkargah \& Kandahar, entering Pakistan at Chaman, all peaceful areas according to Taliban. Apparently unpeaceful are the companies bidding on the project: UNOCAL (US); Delta Oil (Saudi Arabia); \& Bridas (Argentina). Bridas has accused UNOCAL of hijacking the project.

9/8 - AFP - Taliban claimed to have cut all roads to Mazar-i-Sharif.

-IRNA, an Iranian news agency, quotes Hekmatyar as saying the US wants to get Taliban into a war with Iran following Taliban's occupation of all of Afghanistan.

$9 / 9$ - Reuters - Taliban forces claim to have entered Mazar \& captured the airport.

- Afghan online Press says Hezb-i-Wahdat is ready to talk peace with Taliban if it agrees to discuss the arrest of some 2,000 Hazaras in the Taliban-held areas during the past few months \& the over 3,000 reportedly apprehended in Kabul (see 8/26).

$9 / 10$ - News (Pakistan) - Apparently Hezb-iWahdat \& pro-Dostam forces now control Mazar. They may have ousted Malik, paving the way for Dostam's return.

\section{$9 / 11$ - Frontier Post}

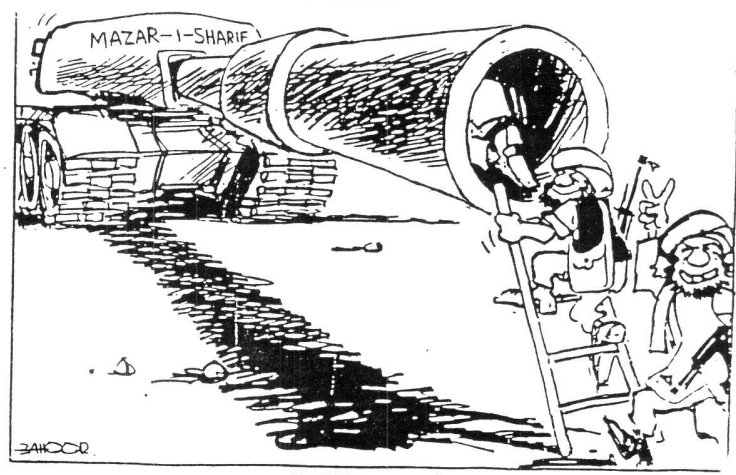


9/14 - Reuters - Traders in Dubai

said Tehran had closed the last transit route to Afghanistan through Turkmenistan in retaliation for the recent abduction of 7 Iranian aid workers in northern Afghanistan.

9/15 - Reuters - Taliban accused Russia of supplying rockets to Masoud.

9/16 - Afghan Online Press reports that Zahir Shah will not return to Afghanistan until he gets a unanimous go-ahead from all parties involved in the Afghan war. "I am bound to honor the wishes of the Afghans \& if they want me I will serve them."

- Dostum repörtedly dispatched a delegation to reconcile with Gen Malik, who is rumored to be stranded in shabargan.

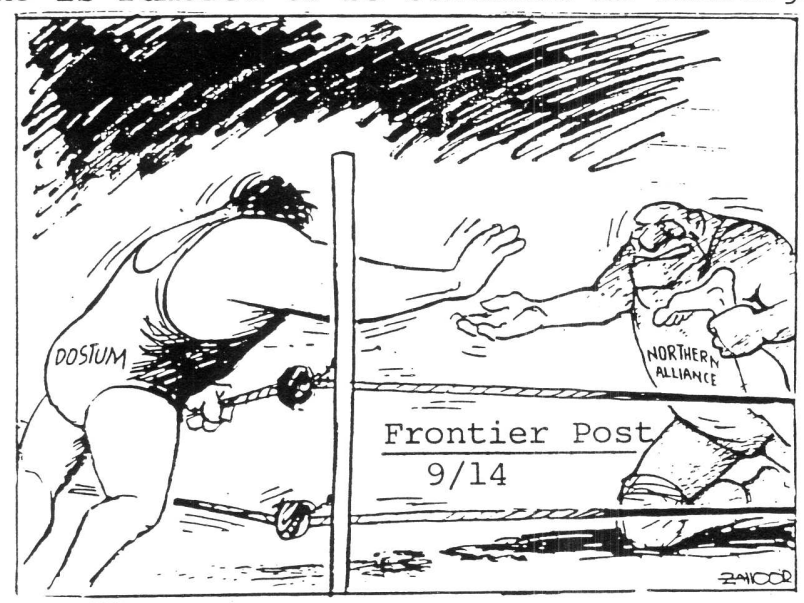

9/17 - Items from the Afghan online Press: Taliban claims that Saudi has pledged assistance to areas under Taliban control. - Gen. Dostum has returned to Afghanistan from Turkey.

- UN agencies are temporarily withdrawing aid personnel from Mazar because their offices have been so looted they can no longer function.

- Dawn claims there are presently 1.2m Afghan refugees in the NWFP.

9/18 - Reuters - Hairatan fell to Taleban forces.

9/21 - News (Pakistan) - Abdul Hadi

Arghandiwal, a leader of Gulbuddin's Hezb-iIslami party was given 24 hours to leave Pakistan. No reason for the expulsion was given.

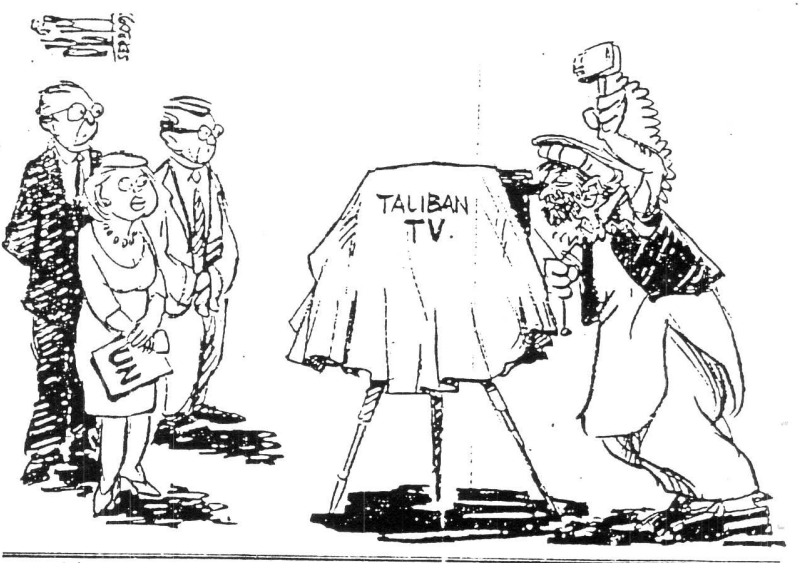

S/21 - Reuters - Taleban told foreign news media, "News which could hurt people's feelings, causes dissension. or ethnic, religious, \& linguistic discrimination should be seriously avoided."

9/22 - Seattle Times - Marty Miller, a Texas oil man, returned from a tour of Mazar \& Kandahar where he pitched UNOCAL's pipeline plans. He thinks the smell of money will inspire the warring Afghan leaders to build a working gov't.

9/25 - Reuters - Taleban ordered all private hospitals in Kabul to close within 5 days.

- Nation (Pakistan) - UNOCAL \& Pakistan have agreed to a price for Islamabad's purchase of gas from Turkmenistan via Afghanistan. Argentina's Bridas company, however, is still very much in the running in the pipeline-building competition.

- UPI - Former Texas congressman Charles Wilson has been accused of taking kickbacks from arms sales to Afghanistan in the 1980 s.

9/29 - Reuters - Taleban arrested Emma Bonino \& 18 others. Bonino, the European Commissioner for Humanitarian Affairs was arrested because members of her delegation took pictures in women's hospitals. The group was held for $3 \frac{1}{2}$ hours before Taleban apologized \& released it.

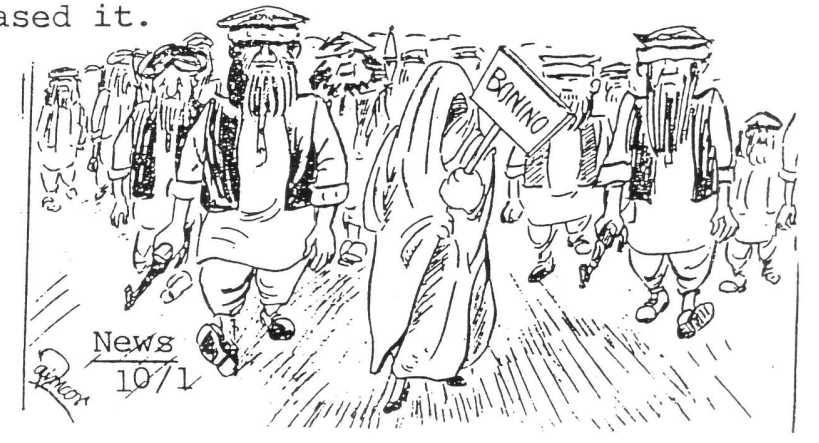


10/3 - Reuters - UNOCAL says it plans to open teaching centers in Afghanistan to train Afghans in pipeline construction. They will start "when an internationally recognized gov't is established."

10/5 - Reuters - Taleban lost control of the airport at Mazar.

10/7 - Reuters - Anti-Taleban forces recaptured Hairatan.

10/9 - AFP - Iran may supply anti-Taliban forces with 20 MIG-21 fighter planes. The planes, reportedly originally belonging to Iraq, have been painted with the Afghan colors. (Iran denies this report.)

10/11 - Afghan online Press quotes Jang (Pakistan) on the latest Taliban decrees: "All pictures of animals \& images of crucifix hanged or kept in houses, shops or other places have to be eliminated as of Monday." Radio Shariat announced a ban on posters, paper pictures \& children's toys. "All vehicles with faces of people or animals, or any other living form, must be repainted." The cross symbol is to be wiped out - from jewelry, buses, trucks, etc., - even though it has no religious significance in Afghanistan.

10/13 - AP - Taliban troops withdrew from Tashkargan yesterday.

$10 / 14$ = Reuters - The ousted Rabbani gov't has set up an "online embassy" to fill the gap left when the US closed Afghanistan's Washington Embassy. Its address is www.afghan-government.com. It will provide information \& fill an "advocacy vacuum."

10/15 - Jang (Pakistan) reports that Gen. Malik returned to Mazar, declared he was still head of Jumbish-i-Milli \& said he had settled his differences with Dostum. Dostum reportedly spends most of his time at the front line, about $70 \mathrm{~km}$ east of Mazar.

10/19 - ACBAR NewS Summary (October) - 28 Afghan groups, excepting Taliban, met in Istanbul \& backed ex-King Zahir Shah's plan for a peace settlement in Afghanistan; they invited him to return to Afghanistan.

10/21 - News (Pakistan) - After a 30-minute battle for Shiberghan between Dostum's \& Malik's troops, Malik was forced to flee to Mashhad. People in Andkhoi \& Saripul raised flags in support of Dostum.
10/22 - ACBAR NewS Summary (October) Dostum was named Vice President of the Rabbani gov't.

$10 / 23$ - ACBAR NewS Summary - The US recently contributed $\$ 3 \mathrm{~m}$ for land mine removal in Afghanistan.

- Reuters -Norbert Holl, head of the UN Special Mission to Afghanistan, will resign as of 12/31/97. Lakhdar Brahimi, a special envoy appointed by Kofi Annan in July, will remain until further notice.

10/24 - Reuters - A sports show celebrated the lst anniversary of the Taleban capture of Kabul although it was a month late due to financial difficulties. Over 3,000 male athletes, covered "from at least above the navel to below the knees" took part. Soccer players wore long :

sleeved shirts \& long. pants.

- The repatriation of about 5,700 Tajik refugees from Afghanistan to Tajikistan will start tomorro

10/26 - Reuters -

Taleban officials have changed the name of Afghanistan

from the Islamic State of Afghanistan to the Islamic Emirate of Afghanistan, accordin to Radio Shariat. The Taleban gov't is recognized by Pakistan, Saudi Arabia \& the United Arab Emirates.

10/27 - Afghan Online Press cites a Voice of America report that Iranian-made weapons are being used by anti-Taliban forces in Afghanistan. Iran says it does not supply the weapons which are available on the open market.

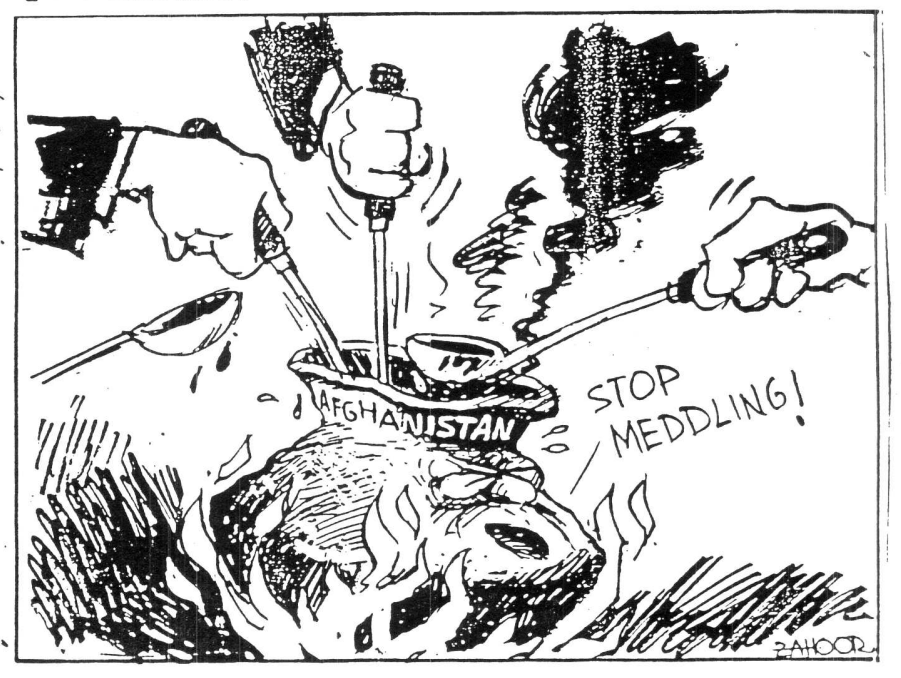


11/1 - Afghan News - The actual work on the trans-Afghanistan pipeline will start as soon as the US recognizes the gov't in Afghanistan, according to Centgas, an 8-member consortium which includes UNOCAL, Delta, Itocho, Crescent as well as companies from Indonesia, Turkmenistan \& Japan. A Russian company may sign later.

$11 / 2$ - Afghan News - Taleban is ready to negotiate with Dostam as he recently released 225 Taliban prisoners.

11/4 - Reuters - The World Health Org. plans to send a team to Afghanistan to check on the quality of public health service for women in territory under Taleban control.

- Taleban are now forcibly cutting hair.

"We are cuteing hair that hangs over the forehead because when you pray, it gets in the way of your forehead touching the ground; the devil stands between you and God," according to Maulawi Abdul Rashid Darkasti of the Taleban religious police force.

$11 / 5$ - Afghan News reports fighting between Dostam's forces \& those of Gen. Abdul Malik near Andkhoy.

- Radio Tehran says Hekmatyar has no plans to leave Iran \& settle in Peshawar. - UN negotiator Norbert Holl says the Afghan factions are not ready to negotiate a peaceful settlement. Therefore the UN will use a new method, maybe trying from the "outside."

11/6 - Afghan Online Press reports that Younos Khalis was flown to Saudi Arabia for medical treatment. His Hizb faction is allied to Taliban.

- Dostum \& Malik are at it again; Dostum reportedly is winning.

11/8 - BBC - Aid workers fear a famine this winter in the Hazarajat due to bad weather, a poor harvest \& a Taleban blockade.

- Afghan Online Press - Maulvi Moh'd Jan has been appointed sec'y of the Taliban Interim Council.

- Taliban claims to have banned all poppy cultivation \& has told the UN that there are no heroin processing laboratories in Afghanistan.

11/11 - Reuters - The UNHCR criticized a German high court decision not to recognize as refugees Afghan asylum seekers who fled the country fearing persecution by the Taleban. The court said German asylum law did not offer protection from civil wars. - Afghan online Press - Restoration work on Babar's tomb in Kabul is underway. The building \& gardens were damaged by rocket fire several years ago. The UN agency sponsoring the project plans to restore the garden which is a public park.

$11 / 12$ - AFP - Taliban said they would welcome Burhanuddin Rabbani in Kabul if he were sincere about peace talks. A spokesman said that both Rabbani \& Sayyaf had requested talks; the fact that both are senior scholars in Islamic law would make them very welcome \& respected, he said. - Radio Free Europe/ Radio Liberty - A UN special advisor on gender issues arrived in Kabul to assist Afghan women in coping with the strict Islamic rules they must now live under. The advisior, Angela King, said she wanted to develop a set of practical guidelines for Afghan women. She also will examine the Afghan operations of the UN which have come in conflict with the Taliban.

$11 / 24$ - NYT - Bye, Bye, Malik:

A powerful Afghian op":

position 'general was reported to have fled to Turkmenistan today after being routed by a former ally, an Afghan news agency reported.

Gen. Abdul Malik fled his headquarters in Maymana, in northern Afghanistan, after supporters of Gen. Abdul Rashid Dostum, his former ally, overran it, the news agency said. It quoted a spokesman for General Dostum, Abdul Baqi Turkistani, as saying General Malik and his brother, Gen. Gul Muhammad Phalwan, fled to Turkmenistan in a helicopter and were in Ashgabat. General Malik had been dismissed as head of the most powerful party in an opposition alliance fighting the Taliban, the news agency quoted General Dostum as saying.

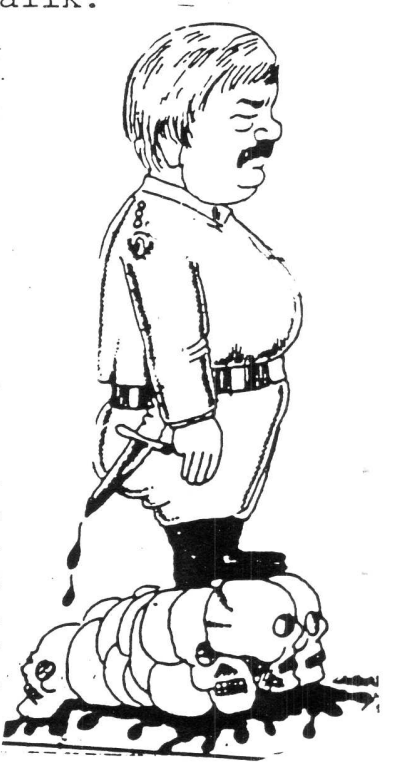

$11 / 30$ - AFP - Taliban asked Iran to hand over Abdul Malik, exiled in Mashhad. They claim he was responsible for the massacre of 2,000 Taliban prisoners 
$12 / 2$ - Reuters - The top of one of the Buddha statues in Bamiyan is being used as an anti-aircraft gun platform \& the caves are being used as makeshift refugee camps. Reporter sayeed Salahuddin writes that holes in the ground bear witness to the poor who scavenge for artifacts to sell for cash. There are cracks in the ceilings of the caves \& many of the frescos are falling to pieces. The Hezb-i-Wahdat store supplies in the caves below the feet of the statues. Some refugees have been living in the caves for over 2 years. Moh'd Jawad Safa is head of the dept. for the preservation of Bamiyan historical monuments but he has never been paid \& demilitarizing the sites resettling the refugees are beyond his ability. He, hopes the UN \& other institutions can help.

- Some Taleban officials:

Maulvi Ahmed Jan, Minister of Mines \& Industries

Maulvi Arifullah Arif, lst Sec'y of the Finance Ministry

Maulvi Shahabuddin Dilawar, Afghan Ambassador to Pakistan

12/3 - Afghan Online Press - A Taliban delegation is in Texas to discuss the pipeline.

- Reuters reports that Taleban, Dostum \& Massoud have been releasing some prisoners.

- Afghan Weekly Update \#243 (UN) - Prof. Paik Choong Hyun, the Human Rights Commission's Special Rapporteur on Afghanistan, will visit the area from $11 / 30$ to $12 / 11$. He will present his report in Geneva in March.

12/4 - Afghan Online Press - Anti-Taliban tribal elders held a 3-day conference in Ispahan \& were pleased with the results which called for a comprehensive peace. Rabbani said, "The united front has no opposition to peace \& at the same time does not insist on monopolizing the powers in the country." Gilani called for identification \& trial of war criminals by the UN \& also asked for an aid fund to be given by the OIC.

$12 / 8$ - BBC reports that conservationists are very concerned about the huge increase in the number of falcon hunters in Afghanistan. So many falcons are now being caught - a hunter can sell one for over $\$ 5,000$ - that naturalists fear they may disappear altogether \& upset the ecological balance in Afghanistan. [! Ed.] Falcons are in demand by hunters in Saudi Arabia \& other Arab countries.

$12 / 9$ - NYT - Asst. Sec'y of state Karl Inderfurth met with a Taliban official in Jashington to discuss human rights \& drug trafficking.

- News (Pakistan) - Gen. Dostum regained fit the leadership of Jumbish-i-Milli pn Monday in Maimana. Former leader Malik, now in Mashhad, claimed he was still the "legal head" since Dostum wasn't chosen in the proper fashion. - AFP - At the OIC conference in Iran, UN Sec'y Gen'l Kofi Annan slammed unspecified "outside forces" for fueling the Afghan fighting. However, he also blamed the Afghans: "Too many groups in Afghanistan... appear to have too much to gain from war \& too much to lose from peace." The Afghan seat at the OIC meeting remained empty.
12/12 - Afghan News - The Afghani has plunged from 24,000 to 28,500 to the US\$. A mysterious supply of crisp new banknotes flooding Kabul seems to be the cause of the drop.

- Pakistan demanded that the Afghan seat at the UN be kept vacant in order to show impartiality. A representative of the Rabbani gov't still holds the seat.

\section{2/13 - News (Pakistan) - Badakhshan Gov.} Syed Amin Tariq says Badakhshan faces starvation if food aid is not delivered to the province. He complained that the UN \& other agencies were sending food to Bamiyan but ignoring Badakhshan.

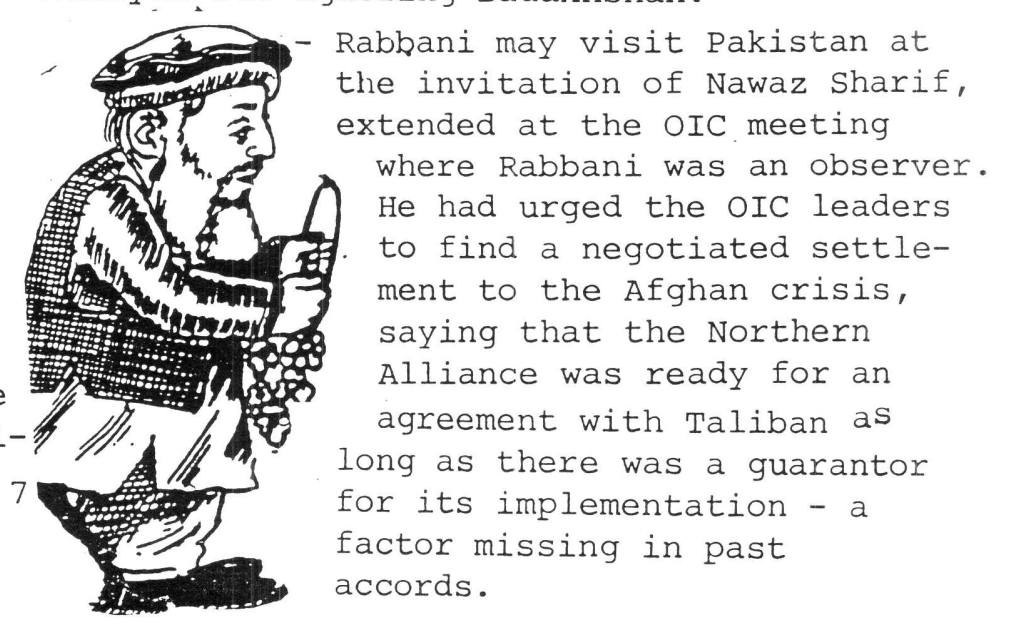

Rabbani may visit Pakistan at the invitation of Nawaz Sharif, extended at the OIC meeting where Rabbani was an observer. He had urged the OIC leaders to find a negotiated settlement to the Afghan crisis, saying that the Northern Alliance was ready for an agreement with Taliban as long as there was a guarantor for its implementation - a factor missing in past accords. 
$12 / 13$ - News (Pakistan) - The US is talking with Tehran about ways of ending the Afghan war. Asst. Sec'y of State Karl Inderfurth has also talked with Ambassadors from China, Pakistan, Turkmenistan, Uzbekistan, Tajikistan \& Russia as well as Iran. The new group is known as Six + Two. The US wants to stop the delivery of fuel \& food supplies to Taliban. - UN investigators are finding evidence of mass graves in northern Afghanistan. A great many of the occupants have their hands ties behind their backs. (See 12/17.) - Masood, Dostum \& Khalili agreed that any peace talks with Taliban must be on behalf of a united front no individual talks are acceptable. [Dostum is apparently the guilty party on this account. Ed.] - AP - 25 women from Afghanistan, most from areas not under Taliban control, are competing in, the 2nd Women's Islamic Games in Tehran. As males are not admitted to most events, the women can wear appropriate clothing.

12/14 - News (Pakistan) - Eng. Faiz

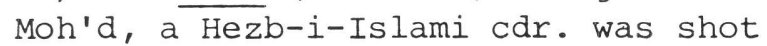
dead in Peshawar Friday night.

12/16 - ICRC Update 97/03 - After 2 months of negotiation with Taliban, women are now being readmitted to Kabul's 2 main hospitals \& female medical staff have resumed work.

12/17 - UN teams investigating reports of massacres in northern Afghanistan have ascertained that many of the reports are true, particularly those concerning Taliban prisoners; Gen. Malik is the scapegoat.

- $\mathrm{BBC}$ reports that the UN has begun airlifting food to Bamiyan. *

12/23 - Nation (Pakistan) - Rabbani arrived in Pakistan, his lst visit in 3 years, in a plane sent by Nawaz Sharif. He was accompanied by representatives from the main antiTaliban groups, Jumbashi-e-Milli, Hezb-e-Wahdat, Harkat-e-Inqilab-e-“ Islami \& Shura-e-Nazaar as well as Jamiat.
12/23 - UPI - UN Special Envoy Lakhdar Brahimi said that "99\% of the people have no stake in the war," but 50,000 "partisans" of various factions "are holding the country hostage \& want to perpetuate the crisis." He said the conflict is fed from the outside for "geo-

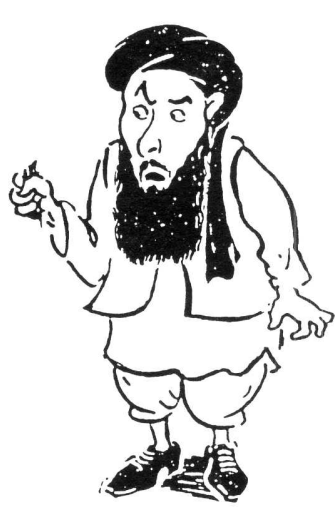

political interests or personal gain."

- Hekmatyar, in Tehran, accused the US \& Russia of fighting a proxy war in Afghanistan.

12/24 - Reuters - Taleban says it is ready to talk peace with its foes providing the negotiators conform with Islamic law \& are conducted by practicing Muslims.

12/25 - News (Pakistan) - Masood's forces have captured Koh-i-Safi \& Najrat \& are heading towards Sarobi. However, AP reports that Taliban launched their lst offensive in Badakhshan \& captured Topkhana \& Zebak. - AP - Taliban's former foreign minister, Mullah Said Moh'd Ghaus, arrived in the US for medical treatment.

- Rabbani appointed 3 more ministers in his cabinet to give representation to Hezb-iWahdat. He has yet to name a new prime minister.

12/27 - AFP - Rabbani proposed a cease-fire during Ramazan \& the setting up of a joint * commission of religious scholars. Dawn reports that a Pakistani team will visit Kabul soon \& that Iran was pleased that Nawaz Sharif had talks with Rabbani.

- AFP reports that Taliban soldiers gave some 120 male Kabulis forced hair cuts \& charged them the normal barber shop price of Afs. 5,000 for the favor.

- Dawn - In Peshawar, the "Oust Afghan

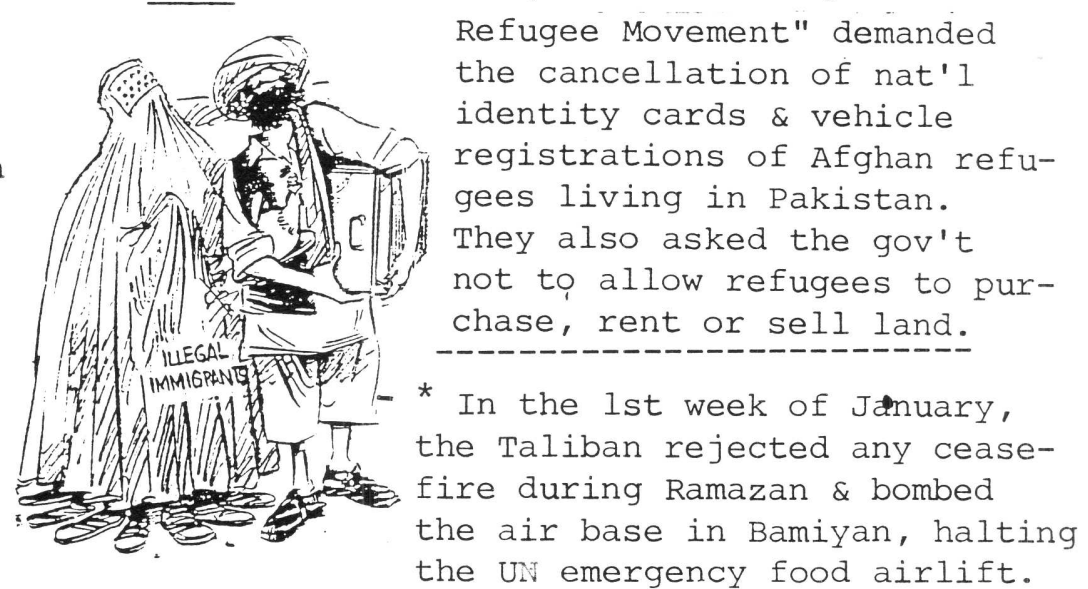




\section{Moon Over Mecca: It's Toughto Pinpoint Start of Holy Month}

Muslims Argue Over Whether To Use New Technology For Fixing Ramadan Date

By.Daniel Pearl

Staff Reporter of 'THE WALL STREET JoURNAL Whoever witnesses the crescent of the month, he must fast the month. (Koran, al Baqarah 2:185)

BIRMINGHAM, England - As they have for centuries, Muslims world-wide will start gazing at the sky tomorrow night to see whether a new moon appears. When it does, Ramadan winl begin the next day, and Muslims will abstain from food and sex during daylight hours for a month to celebrate the revelation of the Koran to Mohammed.

Spotting the moon is a bit more challenging in places like central England than in the Arabian desert, however.

"Here, you don't see the moon for years and years," says Mohammed Khalid on a recent dark afternoon, as a persistent drizzle falls outside his ground-floor office at the Islamic Rosource Center here. In lact, "The last time we've seen the sun was a couple weeks ago."

Different Holidays

Even in good weather, a new crescent moon can be hard to spot, since it may set before the sky is sufficiently dark. With no central authority to guide them, Muslims outside the Middle East often begin and end Ramadan on different days than their neighbors down the block.

But a recent push to take the guesswork out of moon-spotting is further dividing the slamic world:

In a hospital laboratory, Birmingham gastroenterologist Monzur Ahmed demonstrates his Moon Calculator Version 0.3 software, released in December and available free via the Internet. Brushing the dust from his computer screen, he selects "London" and "January 8" and gets a lull-screen simulation of the night sky, with a thin moon in the lower left-hand corner. MoonCalc also produces a full-color nap with a parabola-shaped zone of moon risibility.

Muslims from Malaysia to Califorvia are developing similar moon-visibility calculators, and a slew of computer-generited Islamic calendars are slated for publication this year. In recent years, an lthaca, N.Y., Muslim group called the Committee for Crescent Observation has persuaded most mosques in the U.S. to use such tools to decide weeks in advance when Ramadan will begin.
Saudi Arabian and Egyptian religious authorities, however, have rejected overtures from the observation committee. In the U.K., Islamic scholars met last month and gave MoonCalc the thumbs-down. Traditionalists accuse the moon-calculator advocates of violating the prophet's teachings, sowing discord among Muslims and harming the simplicity of the religion.

"In Islam, there's no need to use a computer," says Mufti Mohammad Aslam of Dewsbury, England, who serves as secretary general of Jamiat-Ulma Britain. a confederation of conservative mosques. Instead, he says, Muslims facing cloudy skies should rely upon sightings from the Middle East; he plans to spend tomorrow evening calling Saudi Arabia every 30 minutes to see if the moon has been seen there. "If it is an Islamic country, we have to believe it," he says.

The trouble is, Islamic countries differ over moon sightings as much as over politics. In 1995, the newly independent Palestinian Authority snubbed Jordan by starting Ramadan one day earlier than Jordan did. Iran rarely starts and ends Ramadan the same day as archrival Saudi Arabia; Libya's sightings have been as much as two days off; Algeria once suffered a false sighting and had to resume fasting after declaring Ramadan over.

According to Islamic tradition, the moon has appeared if two reliable witnesses testify they saw it. But jet trails and the planet Venus can be confused with a young crescent. Also, there is often prize money for the first person who sees the moon, and "it only takes two people out of one billion to create confusion," Malaysian astronomer Mohammad Ilyas wrote in a 1993 paper calling for scientific verification. He found that 14 out of 36 times Saudis reported sighting a new moon when it would have been physically impossible to see. The Saudis "don't want to be behind anyone," says Omar Afzal, a Cornell University linguistics professor who launched the Committee for Crescent Observation's campaign after falling victim to a premature sighting in 1979.

\section{Using Computers Is 'Overkill'}

Mohammed Jibaly, head of a Saudi-oriented religious group in Cincinnati, acknowledges the false sightings but calls them "not very relevant" as long as the witnesses tried to be accurate. Last year, he made a flurry of calls to Nigeria trying to find somebody to vouch for witnesses who spotted the moon there. Mr. Jibaly, who as a physics student used to argue the issue with Prof. Afzal in the Cornell library, says it is "overkill" to use computers to calculate the new moon's appearance.

It is also painfully difficult. Astronomers have no trouble pinpointing the moment when the earth moves between the moon and sun and a new moon is born. But it takes time for the moon to catch enough sunlight to be visible (the current, disputed, binocular-assisted record for spotting the youngest moon is 13 hours, 27 minutes after the alignment occurs).

The precise time of a new moon's visibility depends, among other things, on how high the moon is, how far east of the sun it is, how close the observer is to the equator, and whether lunar mountains are casting shadows that hide the end of the crescent. The computations involve thousands of mathematical operations, and some Muslim scholars are skeptical they really work.

'Subject to Sighting'

"How can you say six months before that it will happen on that day? You're not the one that controls this universe," says Noureddine Hussein Marwan, a Londonbased member of the Saudi-backed World Muslim League. Besides, some Muslims enjoy not knowing the date of Ramadan until the last minute. "It's very nice: People come to the mosque to find out if it's tomorrow," says Dilwar Khan, leaving the East London Mosque after Friday prayers with a calendar marked "subject to sighting of the moon."

But the uncertainty can be inconvenient, too. School boards in heavily Muslim neighborhoods have demanded a fixed date when students will need vacation for the fast-breaking Eid al-Fitr festival at the end of Ramadan. When Muslim groups in the U.K. sought legislation to compel one day's vacation for Eid, they were told to agree on a single date.

At the Brighton Mosque, Dr. Abduljalil Sajid has already determined Ramadan will start Saturday, and plans to use his laptop computer for verification. He has been able to set prayer schedules in advance and organize a cooking crew to help break the first fast Saturday night. "It will ease life a lot," he says.

Knowing the date in advance also gives advocates of the scientific approach a publicity advantage. Two years ago, the Confederation of Sunni Mosques Midlands in Birmingham got the local television station to broadcast the confederation's predetermined starting date for Ramadan. That raised the hackles of traditional mosques.

This year, though, even the astronomy buffs are divided. The Confederation, us ing data from the Royal Greenwich Obser. vatory, projects the moon will appear Thursday. MoonCalc's verdict: The moon will show up Thursday in America, but won't be seen before Friday in the rest of the world.

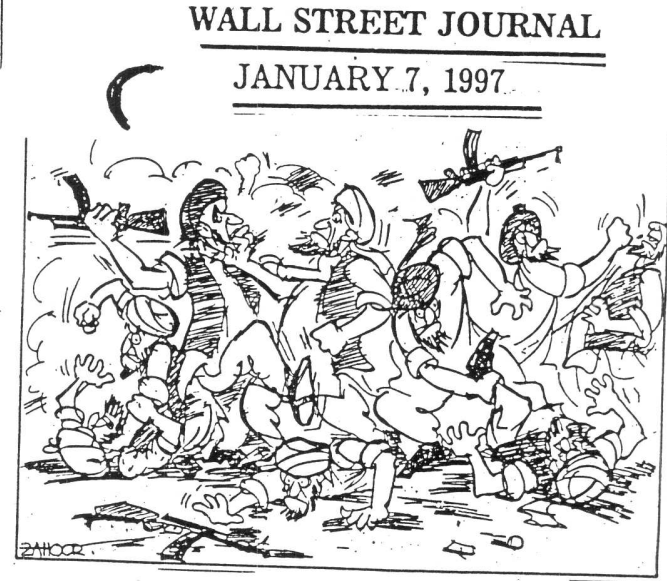




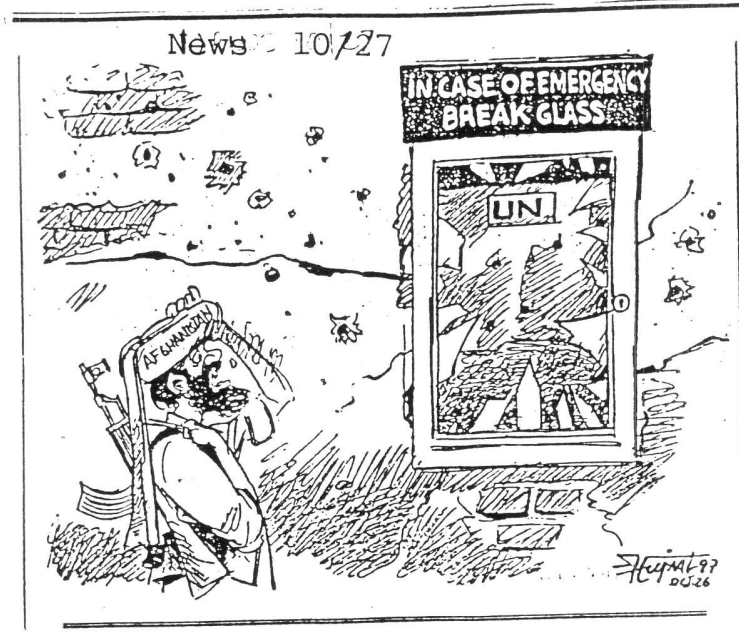

THAT ELUSIVE THING CALLED PEACE

Many Afghans felt happy when the German diplomat Norbert Holl was appointed the special representative of the United Nations secretary-general for Afghanistan in July 1996. They believed someone from the West would be more effective as the UN envoy than those belonging to a developing country. But 15 months later, most Afghans are not only disappointed with Holl but also with the UN. No wonder then that nobody shed tears when Holl recently tendered his resignation.

Holl was the sixth UN special envoy to Afghanistan. The first was the Peruvian diplomat Javier Perez de Cuellar, who later became the UN secretary-general. He was appointed by the then UN secretary-general, Kurt Waldheim, in February 1981 following a proposal by Pakistan that the UN should appoint an envoy to initiate talks among Islamabad, Tehran and Kabul. However, Cuellar's over one-year tenure did not achieve much because Iran flatly refused to participate in any negotiations until the Afghan mujahideen were directly involved in it; Pakistan said it would talk to the communist regime in Afghanistan only through a UN intermediary. On its part, Kabul demanded direct, bilateral talks with Islamabad with minimal UN involvement.

As the next UN secretary-general, Cuellar in early 1982 appóinted a fellow Latin American, Diego Cordovez, as his special representative for Afghanistan. Hailing from Ecuador, Cordovez probably was the most successful UN envoy in Afghanistan as it was during his tenure that the Geneva accords were signed to pave the way for withdrawal of Soviet troops from Afghanistan by February 1989. His was also the longest tenure in this job, which could be one reason why he was more successful.

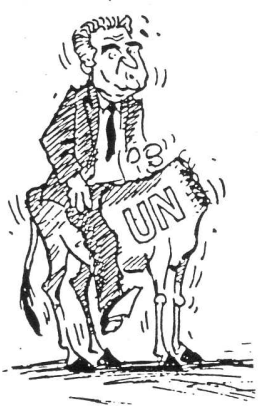

Then came Benon Sevan of Greece who negotiated the botched-up UN plan for transfer of power from the then Afghan president Dr Najibullah to an interim government. The plan didn't materialise and Dr Najibullah never got the safe passage that he was promised by the UN. Instead, he landed up a prisoner in a UN compound in Kabul for four and a half years before being shot and hanged by the Taliban on the very first day of their triumphant entry in the capital on September 27, 1996.

Benon Sevan was followed by Sotorious Misouris, who belonged to Cyprus. His occasional forays into Afghanistan while being based in Islamabad failed to produce any result. During one of his last visits to Peshawar before going home at the end of his fruitless tenure, one remembers him as a forlorn man, disappointed with himself after having failed to inspire the Afghan leaders and people to give peace a chance.

Then came along Mahmoud Mestiri, a former foreign minister of Tunisia. He was old and frail and, unlike a diplomat, he made some unpleasant statements about the warring Afghan factions and neighbouring countries like Pakistan that cost him the goodwill and respect of his hosts and interlocutors. A picture of him walking with the aid of two Afghans while shopping in Kabul's Chicken Street probably proved fatal because the Afghan people want their leaders and peacemakers to be not only wise and pragmatic but also strong and sturdy. They would ask how could a man who himself was in need of crutches show the way to others and produce a peace settlement in a land as harsh and unforgiving as Afghanistan.

One joke often told by Afghans about Mestiri was that a "mestri" (meaning mason in local languages like Pashto and Dari) had been summoned to help achieve a settlement after the failure of all the "engineers" (which meant certain mujahideen leaders like Ahmad Shah Masood, Gulbaddin Hekmatyar, Ahmad Shah Ahmadzai, etc., who claimed to be qualified engineers, even though some of them were never able to complete their education).

Holl was head of the South and West Asian desk at the German foreign ministry before he was made the UN special envoy for Afghanistan. He knew about the region where he was being sent and also spoke Arabic, a language spoken by some Afghan leaders and much-respected by the Afghan Muslims. However, Holl's temper and bluntness often made his task difficult. According to a Western journalist, he was sometimes referred to as Little Napoleon by some of his staff and those who knew him. There are stories galore as to how he would shout at people, including his pilots who performed in extremely difficult conditions while flying in and out of Afghanistan. 
Holl's job contract is to end in December and he will continue until then even though he has resigned. This would also provide time to the UN secretary-general, Kofi Annan, to search for his replacement. There was little likelihood that Holl would have earned an extension in his contract once it became clear that his peace mission was going nowhere. In fact, one soon came to realise that every fresh peace initiative and the launching of the so-called "shuttle diplomacy" by him or Pakistani, Iranian or OIC peace envoys often triggered a new round of fighting and bloodshed. Holl himself had become aware that his efforts to bring the Afghan combatants to the negotiating table were not making any headway and it was, therefore, prudent on his part to quit as the UN special representative.

One single factor which may have prompted Holl to call it a day was Kofi Annan's decision to send the former Algerian foreign minister, Lakhdar Brahimi, on a month-long fact-finding mission to Afghanistan and to countries which were somehow involved in the Afghan conflict. Many interpreted this as a sign of no-trust by the UN secretary-general in Holl because Brahimi's arrival on the scene was like bypassing the German diplomat.

Brahimi's mission aimed at reviewing the UN special mission but in the process it also meant passing a verdict on Holl's performance. Holl did extend support to Brahimi when he visited the region in last summer, but he probably felt so offended after being bypassed that he found it honourable to resign.

Holl's departure couldn't have come at a better time because the UN is contemplating a conceptual change in its approach and priorities while tackling the Afghan problem. A new UN special envoy will be able to start with a clean slate under the changed scheme of things by shifting the focus of attention from the Afghan warlords to the countries which have become involved in the Afghan conflict. This is what Holl hinted at recently and that is what can be the new UN policy while dealing with all those involved and interested in the solution of the Afghan issue.

In fact, the UN has often been criticised in the past for giving too much importance to the armed Afghan groups and warlords and ignoring the rest of the Afghan factions and people. The UN also earned flak for not focusing enough on neighbouring countries like Pakistan, Iran and Uzbekistan along with Russia, Saudi Arabia and the US to stop them from sponsoring some of the Afghan combatants. In their view, there is a proxy war going in Afghanistan due to blatant foreign interference, and the Afghan conflict will remain unresolved unless outsiders are stopped from aiding and abetting their favourites.

It is obvious that the UN has repeatedly failed in its mission to bring peace and stability to Afghanistan. The Afghan people, weary of war after having suffered so much at the hands of both locals and outsiders, were until now banking on the UN to put an end to the bloodletting in their country. Despite the UN failures, they have continued to attach hopes to this world body because none of the neighbouring or other countries involved in the Afghan conflict is capable of mediating in the dispute after having been accused of taking sides in the civil war.

The UN envoys and their staff are also accused of living in comfort in Islamabad rather than sharing the miseries of the Afghan people and evacuating Kabul, Mazar-i-Sharif and other places at the first sound of firing unlike expatriates from the ICRC and certain NGOs who stay put in difficult situations even during times of trouble. The good life which the UN officials lead and the fantastic salaries that they receive also causes heart-burning among the Afghans.

Many Afghans are also at a loss to understand as to why it still recognises the ousted Rabbani regime made up of fractious armed groups instead of the Taliban who occupy two-thirds of Afghanistan. A more even-handed approach would be to leave the Afghanistan seat in the UN vacant as done by the OIC. It is time the UN did some stock-taking as to why its Afghan peace mission has failed and what ought to be done to seek that elusive peace in Afghanistan.

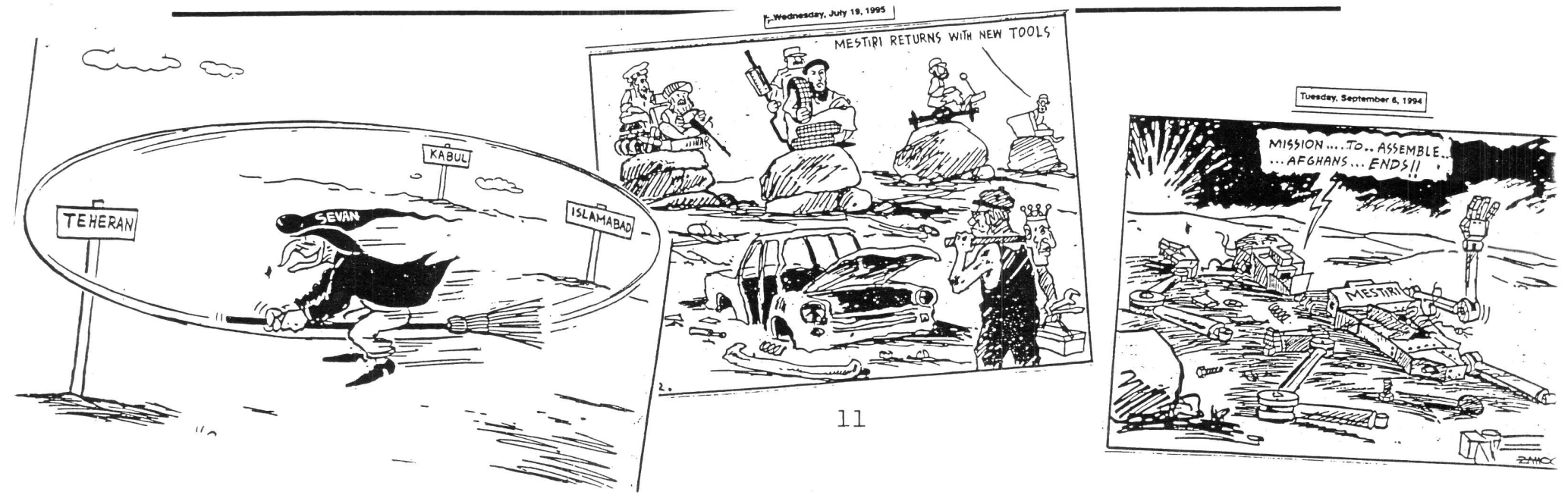




\section{Islamic Rule Weighs Heavily for Afghans \\ lic}

\section{By JOHN F. BURNS}

Ix.KABUL, Afghanistan - Nearly a year after the Taliban Islamic movement cemented its position as the dominant power in this country by seizing Kabul, the Afghan capital is a place of deepening frustration and fear.

-: The white flags that the Taliban raised over Kabul's rooftops on Sept. 27. 1996, signaled the advent of the world's harshest form of Islamic rule. Led by Muslim clerics whose attitudes were forged in Afghan villages that have changed little in 1,000 years, the Taliban announced their intention to create "a pure Islamic society" modeled on the teachings of the Koran.

Women were barred from work and girls from schools. Any female past puberty was barred from even talking to men unless they were blood relatives. Any woman venturing from her house had to have an approved reason, like going to the bazaar for food.

Men were required to grow bushy beards and also came in for a bewildering array of restraints, including taboos on popular pastimes like playing cards, listening to music, keeping pigeons and flying kites. To impose their decrees, the Taliban unleashed an army of armed enforcers who scoured Kabul and other parts of Afghanistan, conducting "beard checks" and other controls on behalf of a religious police force known as the General Department for the Preservation of Virtue and the Elimination of Vice.

A year after the takeover by the Taliban, their unrelenting zeal, reflected in a fresh burst of decrees almost every week, has caused deep despair among most of Kabul's one million people. For many, Taliban rule is an ironic culmination of events that began nearly 20 years ago when Afghan Communists, seizing power in a coup, embarked on their own relentless vision - destroying the mullahs' grip on Afghan society and spreading at least some of the benefits of 20th-century life, including education for women.

In the bazaars, an old Persian word, wahshat, meaning a paralyzing sense of fear, occurs regularly in conversations. Many people seem caught between this fear and an urge to speak out, but they quickly plunge back into something approaching panic.

"God help me if the Taliban come to know that I spoke to you," said a man working in a tiny tailor's shop in the city center. "They would call me a traitor to Islam."

In pickup trucks bristling with guns and rockets, the Taliban are ever-present. Sometimes their destination is a battlefront with anti-Taliban forces to the north. But just as often, young militants roam the city seeking targets.

Sometimes these are men seized for beard checks, then held in freight containers that serve as detention centers until they are ransomed by their families. Sometimes they round up people they label subversives, who are then released to their families for sums as high as $\$ 1,500$, a fortune in a city where many families can barely scrape together enough to buy the day's food.

One Afghan working for a Western aid organization erupted in anger after a morning visiting war orphans, widows and others who receive little or no attention from the Taliban, except for "inspections" to check that no edicts have been breached.

"I'll tell you this, and as a Muslim I never thought I could say such a thing," the man said. "I think we'd be better off under almost any kind of rulers - Hindu, Sikh, Jewish, even Christian - than under these fanatics. Most days, I wake up thinking we'd all be better off dead."

The Taliban have responded to the backlash by saying that the most controversial aspect of their rule, the

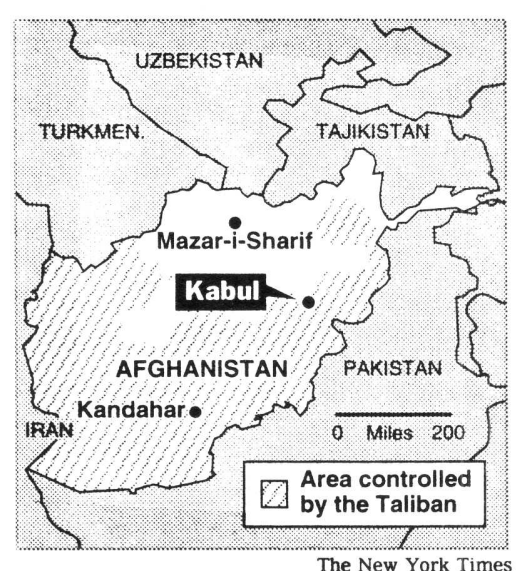

The Taliban's measures have brought fear and anger to Kabul.

exclusion of women from work and girls from school, will be reviewed once the security situation improves.

In May, loathing for Taliban clerics and fighters played a role in an uprising in the northern city of Mazar-i-Sharif that drove the Taliban almost all the way back to Kabul, killing hundreds of Taliban fighters and capturing 3,000 more.

Even with the fighting continuing in the north, the Taliban have tightened their repression. Thousands of men ages 15 to 45 have been arrested and herded into cramped cells in Pul-i-Charki prison, a notorious fortress built by the Communists, on suspicion of being infiltrators for the besieging forces. Foreign reporters have been summoned by the mullahs and warned of deportation if they write unfavorably about the Taliban or attempt any analysis of the situation.

In interviews, several powerful mullahs repeated earlier pledges to give "a positive response" to their opponents pleas' for moderation once their enemies in the north, who control 10 of Afghanistan's 32 provinces, have been defeated. But they quickly reasserted the basis for the restrictions on women, saying they were necessary to prevent Afghanistan's falling into "evil and corruption" that they say women's emancipation has brought the West.

Sher Mohammed Abbas Stanakzai, the acting foreign minister, offered a view he said was reinforced by a visit he made last year to Washington, where he met with top officials of the Clinton Administration to argue unsuccessfully for United States diplomatic recognition of the Taliban. In each day's newspaper, he said, he read of Americans' "intoxication with sexuality" and of its effects, including charges of sexual harassment and rape against Army instructors.

Mr. Stanakzai, 38, speaking English learned in college in India, contrasted this with life for women under the Taliban, which he said respected their "human rights," as well as their nature.

"In Western countries, women come out of their houses almost naked, they go freely to nightclubs, they drink and they dance all night," he said. "And when our society says you cannot do such things, a woman's role is to marry a well-respected gentleman, have children and stay at home, you say we are taking people back to the old ages."

The leader of the anti-Taliban alliance attacking Kabul, Ahmed Shah Massoud, has said the first priority after recapturing the capital will be to restore the rights of women.

The alliance, known as the National Salvation Front of Afghanistan, consists of three separate military forces composed of ethnic minorities - Uzbeks, Tajiks and Hazaras that have traditionally opposed the conservatism of the majority $\mathrm{Pa}$ thans, the ethnic group that predominates among the Taliban.

Meanwhile, the Taliban have continued to tighten their restrictions. Women, required to shroud themselves in head-to-toe garments called 


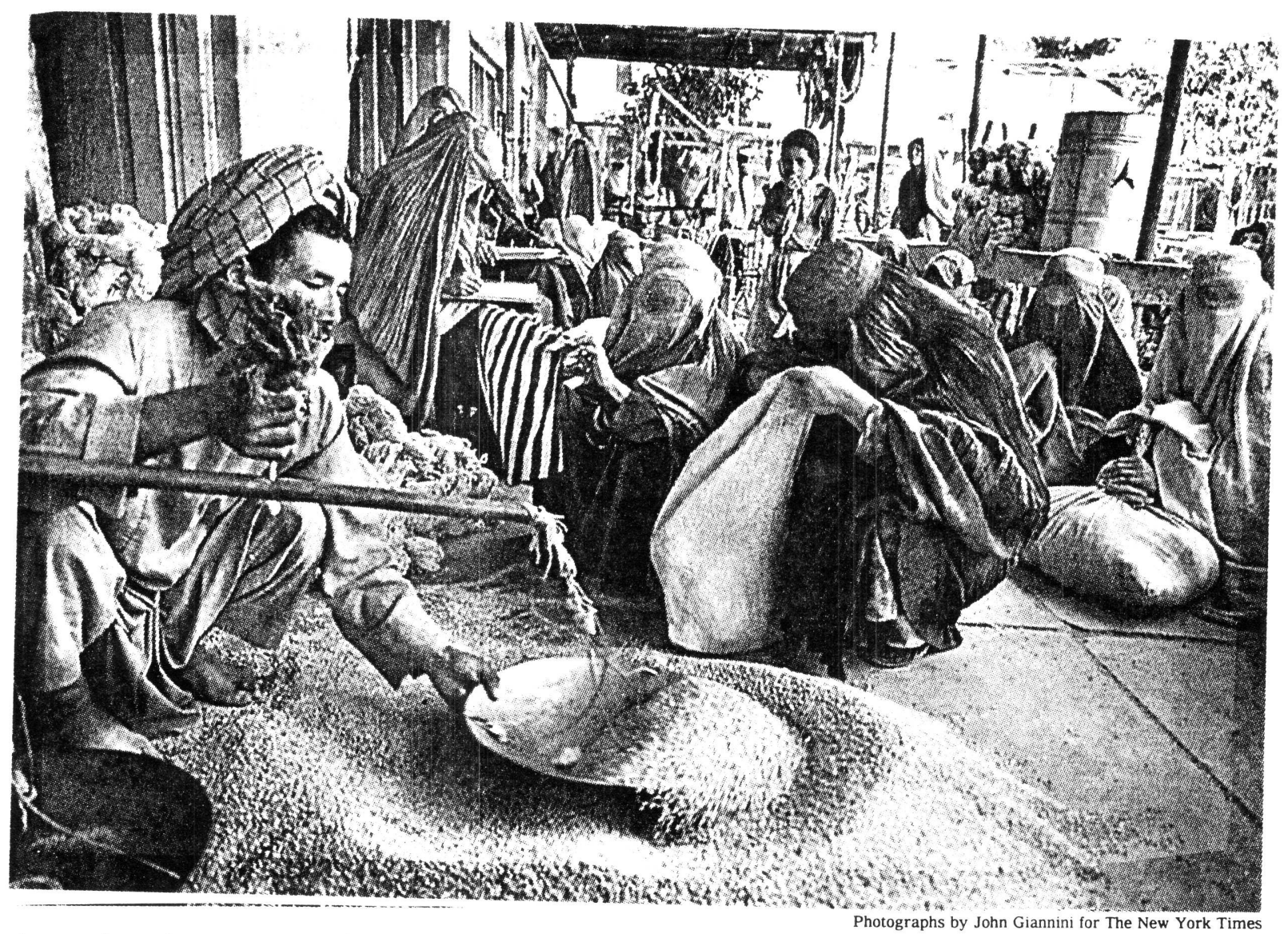

Approximately 36,000 war widows who spin wool for wheat at a United Nations program in Kabul could lose their livelihoods because of the announcement of new Taliban restrictions barring direct assistance to women.

burqas, now risk beatings in the streets for wearing white socks, long a fashion in Kabul but proscribed now by Taliban militants who say they are sexually provocative.

Recently, the mullahs have shown an increasing readiness to close down aid projects, punishing some of the most desperate Afghans, in order to preserve their rules.

Earlier this year, a program feeding 8,000 Kabul children was closed for two months after two Frenchmen working for Action Against Hunger, a Paris-based relief group, were arrested for being in the same compound, though not in the same room, as a group of 60 Afghan women who were not wearing burqas. The women had been invited to a lunchtime gathering to say farewell to two French women volunteers.

After a trial with the religious police acting as prosecutors, the two men were convicted, sentenced to the 30 days they had already served in prison, and deported. Afghan men who were in the compound at the time, including a driver, a cook and a security guard, were sentenced to longer jail terms, and to public floggings, for not acting to stop the women's gathering. The program has resumed, but under conditions that maintain an ironclad segregation of men and women.

Then, in July, the religious police issued a circular saying that all aid programs reaching Afghan women directly should be halted immediately and that the help they offer, including foods, should be delivered through the women's "male blood relatives." If carried out, this would end many programs that have required women to leave their homes, including a United Nations food-forwork project for 36,000 Kabul widows.

Popular disdain for the clerics has been compounded by their failure to evolve into a functioning government. "The Taliban don't even want to govern," said a senior official who has worked for every Afghan government for 30 years, and now spends his days reading old copies of Western magazines that are slid into a drawer as Taliban officials approach. "All they want is the power to say 'No!' to anything strange to their village way of life."

Many Afghans believe that the best hope for the future is that the Taliban will recognize the improbability of uniting the country as long as they refuse to compromise. The evidence for this so far is slim, but there is at least one senior mullah who has concluded that there will have to be changes for the movement to survive.

Mullah Mohammed Abbas, a 50year-old former merchant who is the
Taliban's Health Minister, has made no secret of his impatience with Taliban policies. In an interview, he referred bluntly to the intransigence of "hard-liners" who had opposed his efforts to moderate the policies concerning women in Kabul's hospitals, where exemptions from Taliban rules have allowed women doctors and nurses to continue working.

Mr. Abbas's dissent seemed to go beyond the health field, to the issue of whether the Taliban should share power. Most Taliban leaders have worked hard to keep authority in the hands of a nucleus of Muslim clerics based in Kandahar. Mr. Abbas said he favored a peace agreement that would allow elections and the formation of a Parliament representative of all Afghans, which would decide what kind of Islamic society the country would have.

Perhaps most unusual, Mr. Abbas said that such arrangements would reduce the Taliban's supreme leader, Mullah Mohammed Omar, a 38year-old villager who has only once been to Kabul from Kandahar, to the status of a "ceremonial" figure, without a direct political role.

Mr. Abbas conceded that his view unlikely to prevail. "Many of our people don't want to analyze our situation properly," he said. "Either they can't, or they don't want to. In either case, the result is the same." 


\section{In a Stalemate, Afghan Foes Reload}

\section{By JOHN F. BURNS}

HOTKI PASS, Afghanistan, Aug. 23 - When Abdur Rauf passed through this desolate outpost today on his way to the current front line of the Afghan war, he was filled with the sense of divine mission that comes with being a fighter for the Taliban, the hard-line Islamic movement that controls about two-thirds of Afghanistan.

Leaning through the window of a Japanese pick-up truck, Mr. Rauf, 25, said he was not daunted by the artillery fire echoing beyond the pass, where the forces of a more moderate Afghan leader, Ahmed Shah Massoud, have been probing Taliban defenses. In fact, Mr. Rauf said, he could hardly wait to join his fellow Taliban fighters in one of the rockand-mud bunkers that dot the barren landscape here.

"I am not afraid of dying, because this would be martyrdom," he said, fingering a cloth-wrapped copy of the Koran that was wedged between the dashboard and the windshield of his vehicle. "The Koran teaches us that it is a blessing to die for Islam, and that God will give me paradise in return."

For Mr. Rauf, and for dozens of Taliban fighters encountered on the Shamwali plain north of Kabul, the Afghan capital, it seemed to matter little that the fighting raging near here places the Taliban back where they were almost a year ago. In the first week of October 1996, after the Taliban captured Kabul from $\mathrm{Mr}$. Massoud's forces, the battle front on one of two roads running northward from Kabul to the Hindu Kush mountains was just where it is now, at Hotki Pass.

Earlier this year, Taliban troops virtually rolled over the Massoud forces and two allied opposition groups. By late May, the Taliban had entered Mazar-i-Sharif, a city 250 miles north of Kabul that has been the principal stronghold of the socalled northern alliance forces. For a moment, it looked as though the war might soon be over. But the Taliban forces overreached, suffering a debacle that cost them about 400 men killed, at least 3,000 captured, and a humiliating retreat almost all the way back to Kabul.

In Mazar-i-Sharif, Taliban commanders attempted to impose their harsh form of Islamic rule on a population accustomed to a more moderate way of life. This ignited ethnic hostilities, too, since Taliban forces are composed overwhelmingly of Pashtuns, the mainly southern group that accounts for more than 40 percent of the Afghan population of be- tween 15 million and 20 million, while the northern alliance brings together forces that represent the minority Tajik, Uzbek and Hazara populations concentrated in the central and northern regions of the country.

Three months later, the war appears to have reached a stalemate. For three weeks, the Massoud forces have been stalled, controlling a salient that runs south from the southern escarpment of the Hindu Kush along the so-called "old road" across the Shamwali plain to a point about 12 miles north of Kabul. Along the second major road that crosses the plain, the so-called "new road" that runs 10 miles farther east, the Massoud forces have been held at Hotki Pass, about 20 miles from Kabul.

As in much of the fighting in Afghanistan in the last 20 years, life at the front is a desultory affair. Only rarely do opposing forces encounter each other in infantry battles. Instead, they stand off across a noman's land of several miles, firing salvoes from Soviet-made field guns and rocket launchers. Occasionally, a shell or a rocket falls on an enemy bunker or encampment, but more often it is civilians in the villages that dot the plain who are the casualties.

According to officials of the United Nations High Commissioner for Refugees, nearly 200,000 people have fled the Shamwali plain this year. This represents most of the population of a region that, in its more fertile areas on the western side of the plain, has been Kabul's traditional breadbasket.

The exodus has swollen the already overstretched capacities of the capital, where about a million people struggle to survive in a city that is at least two-thirds rubble from earlier phases of the war.

Kabul is an ever more desperate place. The streets are filled with beggars of all ages, their hands reaching for the few ragged Afghan notes that will buy one of the flat, oval-shaped loaves of bread called nan that are the basic Afghan diet. Most supplicants are men and boys. But despite the Taliban's repressive rules for women, which have included closing all schools for girls, banning women from holding jobs and ordering women to stay off the capital's streets, small groups of women continue to defy the edicts, many of them to join in the begging.

Western aid officials calculate that at least a third of the city's population, perhaps a half, depend on food handouts from aid agencies. But the desperation seems to have little im- pact on the men who prolong the war, who continue to speak, as military commanders in Afghanistan have done for two decades, of the breakthrough that will bring final victory, or at least such a weakening of opposing forces that terms of peace can be dictated.

Mr. Massoud has gone from predicting the recapture of Kabul by his forces in a matter of days to acknowledging this week that the Taliban's ouster from the capital is more likely to be a matter of "weeks, or possibly months." In fact, Western military observers in Kabul say, $\mathrm{Mr}$. Massoud appears to have accepted that a push for the capital, even if successful, would only mean swapping places with the Taliban, in the sense that Mr. Massoud would then be hard-pressed to hold the city against Taliban counterattacks.

For their part, the Muslim clerics who control the Taliban have continued to demand the surrender of Mr. Massoud's Jamiat-i-Islami forces, and those of his allies, the Junbish-iMille group led by Gen. Abdul Malik and the Hezb-i-Wahdat of Abdul Karim Khalily. United Nations negotiators who have shuttled unavailingly between opposing Afghan forces for years have been told that the northern alliance forces must free all prisoners taken in Mazar-i-Sharif, lay down their arms and accept the purist form of Islamic rule prescribed by the Taliban.

That leaves little prospect except continued war, something that appears to create few anxieties on Taliban front lines. When the movement arose three years ago in the region around the southern city of Kandahar, the Muslim clerics who founded it said that ending the war was their main objective. But now, that appears to have been superseded by the desire to impose the Taliban's millennial vision on all of Afghanistan, something Mr. Massoud and his allies, as well as many ordinary Afghans, say they do not want.

"Of course, we would like peace for the poor and oppressed people of our nation," Mr. Rauf, the Taliban fighter, said as he prepared to move toward the front. "But compromise with infidels like Massoud is not possible: The only solution is for him to accept the cause of pure Islam, and then there can be peace for all Afghanistan."

\section{THE NEW YORK TIMES}

AUGUST 24, 1997 


\section{U.N. Investigates Report of Slaying of 2,000 Taliban Fighters \\ i..}

$\because$ BY BARBARA CROSSETTE

:. UNITED NATIONS, Nov. 17 United Nations officials are looking into reports that as many as 2,000 fighters from the Islamic Taliban movement were killed and buried in mass graves after being taken prisoner in northern Afghanistan by forces of the coalition driven out of Kabul last year.

The representative of the ousted Government of Burhanuddin Rabbani, which still holds Afghanistan's United Nations seat, was called in today by United Nations officials and asked for an explanation.

The discovery of the graves was made public today in Afghanistan by Gen. Rashid Dostum, a warlord still fighting on the Rabbani side.

The graves were found in Jozjan Province about 90 miles east of Mazar-i-Sharif, a northern stronghold of the former Government. In May, a fracture in the coalition forces led to a brief alliance between the Taliban and Gen. Malik Pahlawan, a rival of General Dostum.

General Pahlawan soon broke with the Taliban forces and attacked them in Mazar-i-Sharif, where they were trapped. Many who were not killed were taken prisoner. "The whole northern alliance is responsible for these killings," Abdul Hakeem Mujahid, the Taliban's representative-designate to the United $\mathrm{Na}$ tions, said in an interview today.

He blamed the United Nations, human rights groups and the news media for not listening when some prisoners escaped reached Kabul with stories of atrocities and executions of soldiers in groups, night after night.

"We are very, very sorry about the attitude of the United Nations and human rights organizations, because have repeatedly told them that our

prisoners are being killed in Mazar-iSharif, and they didn't take notice. Mr. Mujahid said. "Even in meetings with the State Department, I have spoken about the collective killing of our prisoners.

"If the hair of a person is being cut in Kabul, the whole media is talking about it," he added. "But 2,000 people being killed, and there is no serious interest."

By contrast, he said, the Taliban had released several thousands of prisoners captured on their drive into the north, a region populated by Uzbeks, Tajiks and other ethnic groups traditionally at odds with the Pathans who form a majority of the Taliban.
Relief agencies and United $\mathrm{Na}$ tions mission staff in Afghanistan Mazar-i-Sharif because of fighting and have no first-hand information on the graves, but officials say the story of prisoner massacres may well be true.

Today Lakhdar Brahimi, a former Algerian 'Foreign Minister who is General Dostum's special representative for Afghanistan, and Kieran Prendergast, Under Secretary General for Political Affairs, asked the United Nations office in Kabul for an investigation into the reports of mass graves at the request of Secretary General Kofi Annan. “The Secretary General asked that the mission in Afghanistan tell us what they know," Mr. Brahimi said in an interview. "We don't want to jump to conclusions before' we find out a little bit more. But we are certainly concerned."

Taliban Supporters say pro-Iranian groups fighting with the ousted coalition may have also been involved, with the aim of inflaming interethnic strife within Afghanistan.

Taliban representatives were told here that General Dostum, who is not considered pro-Iranian and who may be attempting to discredit General Pahlawan, had not only disclosed the graves but also offored the use of an airfield to evaoulate the bodies. have not been able to work around

THE NEW YORK TIMES NOVEMBER 18. 1997

\section{BODK REUIEW} 1997. the chaos.

\section{Pakistan Said to Allow Food Airlift to Afghans}

ISLAMABAD, Pakistan, Nov. 27 (Reuters) - The Pakistani Government has agreed to let the United, Nations airlift food to central Afghanistan from the northwest border town of Peshawar, the United Nations said today.

The airlift, which will circumvent a five-month blockade of the Hazarajat region by Afghanistan's Taliban militia, will begin within the next few days, the United Nations said.

It will be carried out by the World Food Program, which says that 1.2 million people are affected by the blockade and that 160,000 of them risk famine because of crop failure, floods and frost.

The Taliban has rejected appeals to lift the blockade, saying the food would fall into the hands of opposition factions that control the region.

The United Nations has given assurances to the contrary, but the Taliban insist that the food should be delivered from opposition-held northern areas of Afghanistan, where United Nations stocks were looted earlier this year.

NOVEMBER 28, 1997

NEW YORK TIMES

HISTORICAL DICTIONARY OF AFGHANISTAN, 2nd Edition, by Ludwig Adamec, Lanham, MD \& London, Scarecrow Press

Anyone with a more than passing interest in Afghanistan is indebted to Ludwig Adamec for his many volumes describing events in Afghan history and sorting out the casts of characters involved. This latest work is a welcome addition even though many of the cast members featured in the current drama are as yet unmentioned. We received our copy a few davs after Rabbani's Prime Minister, Abdul Rahim Ghafoorzai, died in the plane crash in Bamiyan. Our search for biographic information in the new book was in vain even though Ghafoorzai had been on the Afghan political scene for some time. Perhaps many in the current cast appear too fleetingly to have historic impact. We hope Prof. Adamec is planning his next volume; maybe he can straighten out

MAS 


\section{By JOHN F. BURNS}

KABUL, Afghanistan, Aug. 28 Not much in the manner of Alhaj Maulavi Qalamuddin suggests that he is one of the most feared men in Afghanistan.

The tall, muscular Muslim cleric with the bushy beard and long-tailed turban is a study in gentility, at least toward visitors. He begins by offering cups of green tea. Even when the topic is deadly serious, he has a way of breaking into a barrel-chested laugh.

But Mr. Qalamuddin is the head of the General Department for the Preservation of Virtue and Prevention of Vice, the religious police of the Taliban, the Islamic movement that controls most of the country. Under his command, thousands of young men known as "mohtaseb" - an Arabic word that translates roughly as "inquisitors" - roam the land, watching for infringements of the Taliban's taboos, arresting some offenders and meting out summary beatings and floggings to others.

Some of these enforcers roar through dusty streets on Japanesemade pickup trucks equipped with chrome roll bars and flashing blue lights, peering out of the windows through a forest of Kalashnikov rifles and rocket-propelled grenades powerful enough to punch a hole in a tank. Others patrol on foot, often with rifles, sometimes with switches fashioned from tree branches or lengths of electric cable.

Their role is to insure conformity with Sharia, the ancient Islamic social and penal code. The Taliban have ordered the stoning to death of couples caught in adultery, the amputation of the hands and feet of thieves, and public executions where male relatives of rape and murder victims act as one-man firing squads.

Such punishments are not unknown in Saudi Arabia and other conservative Islamic societies. But Taliban rule has also come to mean floggings for women who allow faces or ankles to show beneath the head-totoe shrouds called burqas that the Taliban have made mandatory. Other Taliban taboos include bans on women talking to men who are not blood relatives, making themselves visible to passers-by through the windows of their homes, or traveling in cars, buses or trucks alongside men who are not from their family.

Recently, there have been cases in Kabul in which Mr. Qalamuddin's men have beaten women for wearing white socks or plastic sandals with no socks, attire Taliban zealots have said was likely to provoke "impure thoughts" in men. Asked about these cases, Mr. Qalamuddin said there had been no formal decrees on socks or sandals, only one that admonished women to "walk calmly and avoid creating noise by their footsteps.'

But the cleric, a veteran of years of fighting against Soviet occupation forces in Afghanistan in the 1980's, as much as confirmed that women are at risk of a flogging if anything about their feet or legs arouses suspicion among his men.

"Some women want to show their feet and ankles," he said. "They are immoral women. They want to give a hint to the opposite sex.'

True to his strict interpretation of Islamic teaching and its proscription of images of the human figure, $\mathrm{Mr}$. Qalamuddin refused to be photographed. But many Afghans complain that the Taliban militants make up taboos as they go along. In the villages where most of the young, illiterate Taliban recruits come from, contact between men and women outside of family and marriage has always been forbidden, a frustrating circumstance that bet-

1 ter-educated Afghans see as a possibłe spur to Taliban violence against women.

A! though women are the main victims of the "virtue and vice" teams, men are not immune. In an incident this summer, Mr. Qalamuddin's men hid on the roof of a house in the center of Kabul, waiting until men in an adjoining house began watching a video of an Indian dance movie, a popular genre in this part of Asia. According to a neighbor, one of the men seized by the Taliban, a 25-yearold welder who had been deaf since birth, died in custody within 48 hours.

Stories like this abound in Kabul, but Mr. Qalamuddin denied that the Taliban have unleashed a terror. On the contrary, he said, the Taliban have brought a measure of "peace and security" to the country that had been absent throughout the years of Communist rule, guerrilla conflict and civil war that preceded the Taliban. Indeed, he said, the promise of a return to order was what enabled the Taliban to rise from village obscurity to control of most of the country in barely three years.

Refering to a stoning of two adulterers beside a mosque in the southern city of Kandahar last August, he chuckled, saying it had been one of the Taliban's most successful demonstrations.

"Just two people, that's all, and we ended adultery in Kandahar forever," he said. "Even 100,000 police could not have the effect that we achieved with one punishment of this kind."

Taliban leaders often say that
Western reporters and human rights organizations exaggerate the importance of Taliban rules banning women from working, denying education to girls, and restricting women and girls past puberty to domestic seclusion. But Mr. Qalamuddin's elaboration on what he depicted as the everpresent dangers of sex lent weight to a common impression among ordinary Afghans that it is the Taliban, not their critics, who are obsessed.

Mr. Qalamuddin laid out a view of relations between men and women that seemed rooted in an Adam-andEve view of men as deeply vulnerable to corruption through unregulated contacts with women. In Islamic society, he said, these risks had been curbed by rules tnat strictly limited male-female encounters. "If we consider sex to be as dangerous as a loaded Kalashnikov rifle, it is because it is the source of all immorality," he said.

Mr. Qalamuddin contrasted this approach with Western sexual attitudes, an issue many Taliban clerics seem keen to discuss. "Young women in your society come into public parks and walk around half naked for all to see," he said, smiling. "In this case, what is the difference between a public park and a jungle? Does not behavior like this reduce men and women to wild animals? In Islam, we say that it is our duty to tame these corrupt instincts."

"The outside world, in conjunction with our enemies at home, have unleashed a false propaganda against us, that we are violating women's rights," he said. "But the reverse is true: the world should take lessons from us. By strictly observing the Sharia law, we have given great honor and dignity to our women."

THE NEW YORY TIMES $=$ AUGUST 29, 1997

Too Late to Classify:

$12 / 28$ - BBC reports that Taleban has agreed to form a commission of Islamic scholars from both sides to try to end the war. Taleban said if it approved of the commission members, it would abide by any decision it reached.

- Reuters - UN Special Envoy Norbert Holl, ending his Afghan assignment, said he saw new hope for peace talks. "Maybe we have reached a stage where hope is legitimate." 


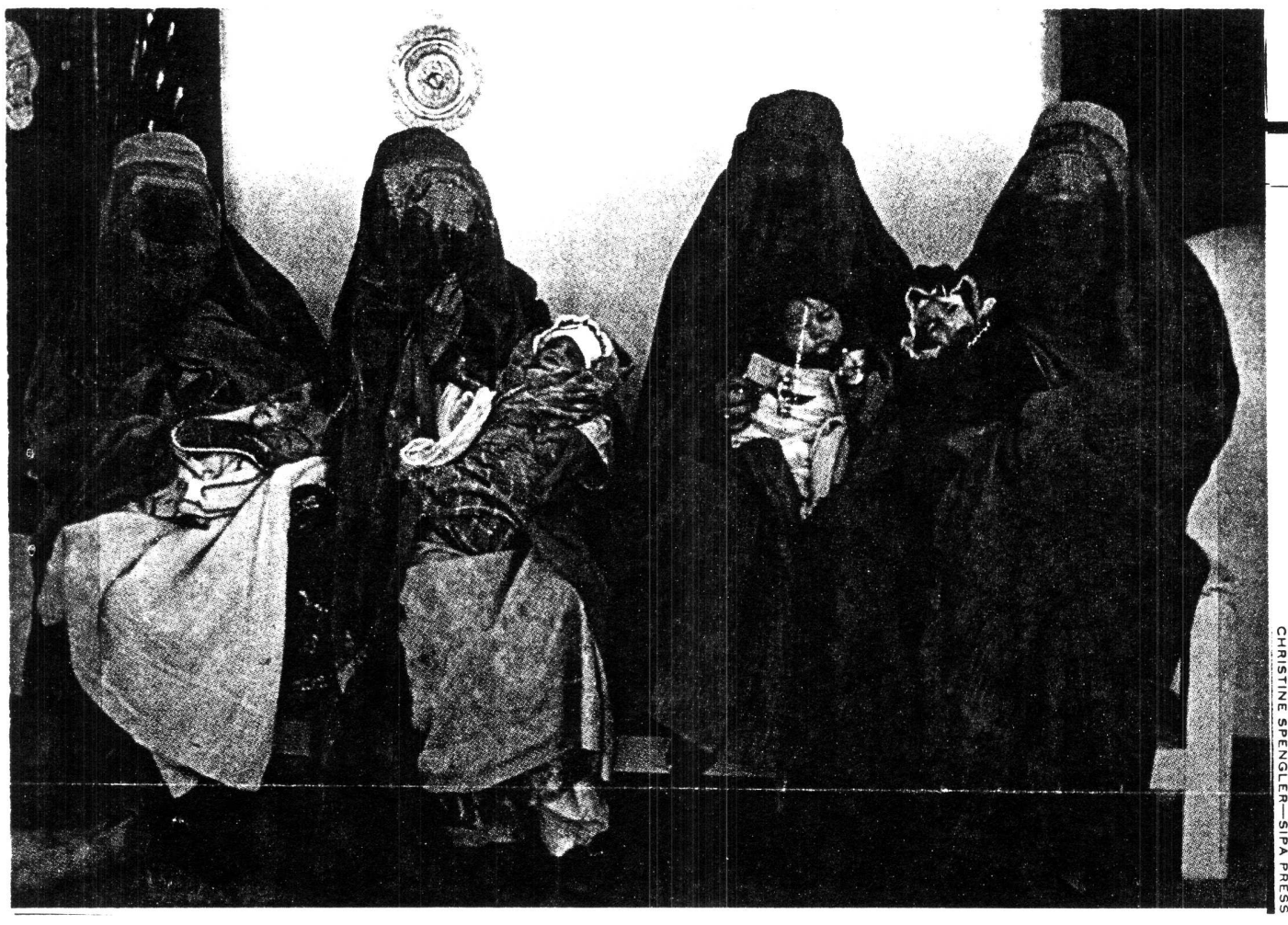

W $O$ O $R \quad$ L $\quad$ D

\section{Tyranny of the Taliban \\ A visit to the capital of Afghanistan's extremist regime reveals a harsh world of suppression and despair}

\section{By CHRISTIANE AMANPOUR KABUL}

W

E WERE STANDING IN KABUL'S ONLY hospital for women when the purist authorities of the Taliban decided they did not want any pictures taken. Screaming and shouting at us, they grabbed our TV cameras, all our tapes and even our briefcases. Several armed Taliban enforcers slapped a cameraman, while another rammed his rifle butt at visiting aid workers. One raised his hand toward Emma Bonino, the European Union Commissioner for Humanitarian Affairs, there to investigate the Taliban's treatment of women, and would have struck her but for an aide's intervention. The next thing we knew, a truckload of armed men were escorting us to the central police station. After several hours, they freed us and returned our cameras but refused to give back the tapes. "Now I know," says Bonino, "what the people of Kabul have to live with every day.”

The Taliban does not seem eager for the outside world to see how it has been ruling Afghanistan since its fanatical fighters stormed into the capital of Kabul a year ago. Here the young, often illiterate "students," who developed their extremist interpretation of Islam in the refugee camps of Pakistan during the 1979-89 war against the Soviet occupation, are a law unto themselves. In 1996, when my CNN team witnessed the beginning of their enforcement of their version of Koranic law, I challenged Taliban "ministers" to explain, and they told me all women's rights would be restored "once the security situation improves."

One year later, the security situation remains dangerously unsettled. The Taliban has consolidated its hold over two-thirds of the country but is still fighting to extend its harsh rule over the entire

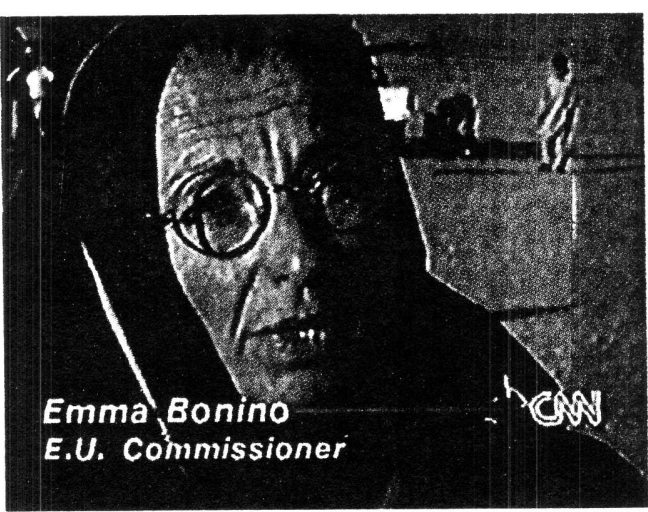

HARD TIME: The European Union's top humanitarian was briefly detained by the Taliban
DESPERATE DAYS: Women in Kabul are forced to live in a strict, modern purdah

nation. In the past year, the women of Afghanistan have endured extraordinary hardship, and last week's incident proved that the Taliban has no intention of easing the stern commandments that have virtually locked women away in a modern purdah.

From the day they marched into Kabul, the Taliban's adherents have sought to eradicate women from public life. In a land where the women have had to work while the men fought, the regime has barred females from taking any job outside the home or even leaving their houses without a male relative to accompany them. Girls have been thrown out of school. Foreign-aid agencies have been forbidden to offer any of their services or assistance directly to females.

Today Afghan women cannot even expect proper medical care. Three weeks ago, the Taliban decreed that female patients could no longer be treated at any of the main hospitals in Kabul and would be completely separated from male patients and medical personnel. We discovered that sick women are being sent to a crumbling old building that has no windowpanes, no running water, no proper operating room and barely enough electricity to power lightbulbs. The patients are tended by a meager femaleonly staff.

In our two-day stay in the capital city we watched agents for the Preservation of Virtue and Elimination of Vice enforce an endless list of edicts andabsurdities at gunpoint, with rifle butts, with the backs of their hands. Women are forbidden to wear high heels or white socks because they are considered a sexual lure. Music is banned: cassettes are often snatched out of cars, the tapes stripped out and hung on signs as a warning. Kites may not be flown, and most forms of public entertainment, like movies, are not permitted.

The toll such measures take on Afghan women is impossible to assess. Several told us how dispiriting it is to be thrown off a bus or forced to sit in the back. We heard reports of an increase in the suicide rate among females, and that many have sunk into despair and depression. For Afghanistan's tyrannized women, there is no escape from an unsparing, medieval way of life.

Christiane Amanpour is chief inter national correspondent for CNN. 


\section{Where the Music Has Died, and the Women Walk Softly}

By William Shawcross

KABUL

I recently drove into Kabul along an exquisite road winding through the mountains past fortified ocher villag. es. Close to the city, we were stopped at a road block. Nearby was a pole festooned with yards and yards of tape fluttering in the breeze-all of it torn from cassettes seized from the cars of passing drivers.

Under the fundamentalist Islamic government that controls the capital of Afghanistan, cassette tapes are banned, as is live music of any kind. For a time at least, so were kite flying and soccer. These days, some children are flying kites and playing soccer-but clapping or cheering after goals is still forbidden.

The Taliban, as the forces of the movement are known in the country, captured Kabul in September 1996, the latest turn in a war that has been raging since the Soviet Union invaded Afghanistan in 1979. Many people in the city had hoped that their arrival would mean an end to the civil war that has assaulted the Central Asian country for almost two decades. But the war continues; the Taliban has not yet captured the north of the country, where its enemies are supported by both Russia and Iranboth of whom fear the Taliban's fundamentalism. In recent weeks, the Taliban forces have more territorial gains but are not yet in a position to control, much less to govern, the whole country. There seems little prospect of a negotiated compromise to end the war.

The Taliban has imposed a kind of order in the Afghan capital-but it is pacification, not peace. Its small occupying forces see the capital as a den of, evil that must be cleaned and scourged. (A Talib is "one who seeks," as opposed to a mullah, "one who gives.")

Last week, Secretary of State Madeleine Albright attacked the Taliban while on a visit to Pakistan, one of the Kabul regime's principal allies. "It's very clear why we are opposed to Taliban," she said. "We're opposed to their approach to human rights, to their despicable treatment of women and children, and their lack of respect for human dignity in a way more reminiscent of the past than the future."

These are strong words and will perhaps go some way toward correcting one prevailing conspiracy theory in the region:

That because Pakistan was a vital Cold War ally of the United States against Soviet occupation of Afghanistan, and because Pakistan supports Taliban, Washington must-at least secretly - be supporting the Taliban forces. No way, says Albright.

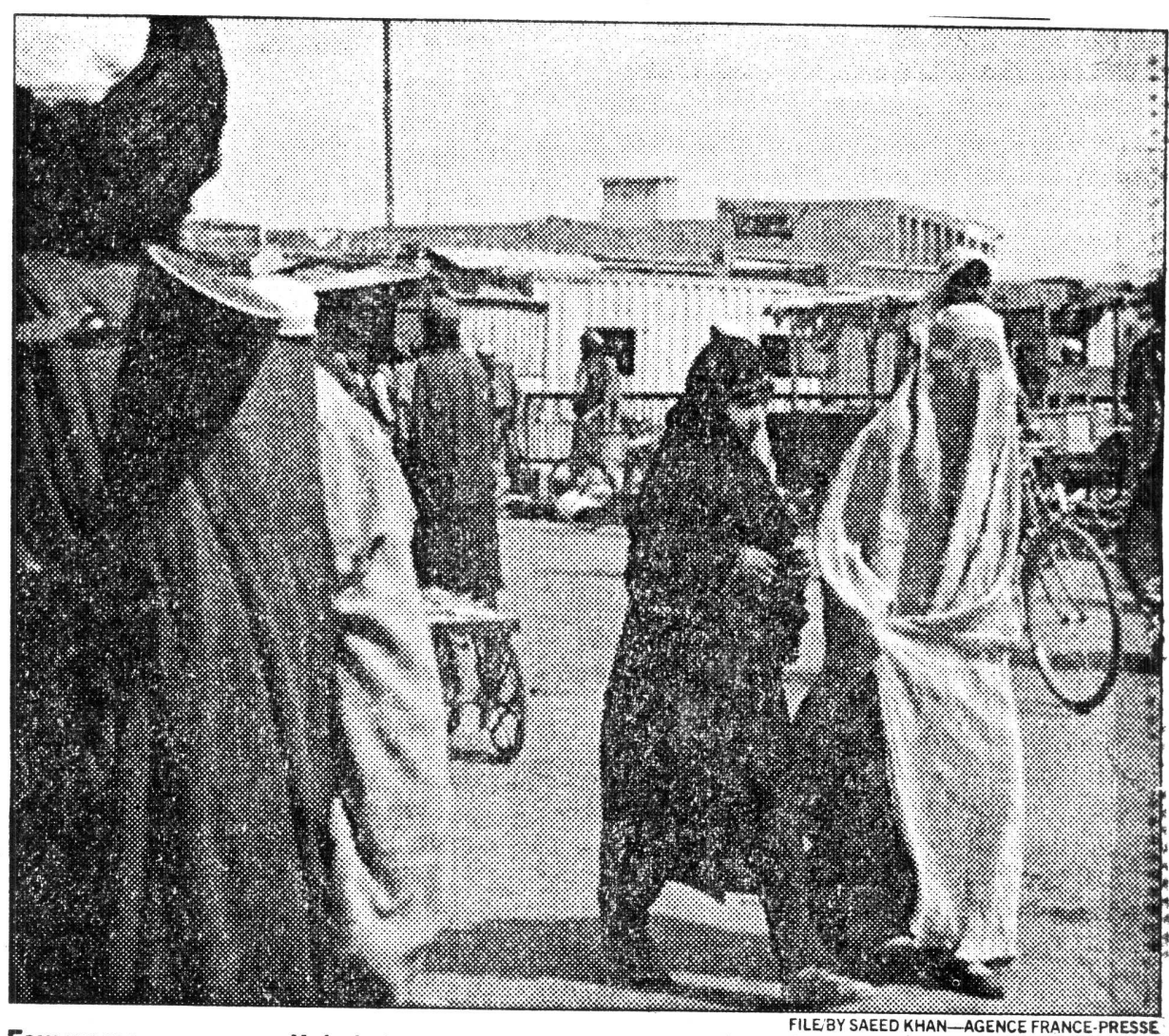

Few women appear on Kabul streets; If they are not properly attired, they risk being beaten by the Taliban. The United States has called its treatment of women and children "despicable."

Nothing prepared me for the destruction of Kabul. We drove through miles of ruins to get to the inhabited part of the city. Well over half of the houses are said to have been smashed to the ground in the civil war of recent years. On one side of the town, street after street is reduced to piles of rubble, most of which is not only useless but dangerous; it has been seeded with thousands of land mines, some of which foreign non-governmental organizations are attempting to clear with the help of Afghan workers.

Apart from the destruction, two other aspects of life under the Taliban are very noticeable.

First, the women of Kabul are conspicuous by their absence. They are discouraged from appearing on the streets and, if they do so, are enveloped in bell-like tents known as burqas that cover them from tip to toe. Only their eyes are visible, behind an opening in the cloth.

Women cannot work; they cannot take taxis or buses unescorted by their husbands or fathers. Girls cannot go to school. This means that few boys can now go, either-because so many teachers were women. The classes that still exist often have 200 boys apiece.

Second, the men of Kabul are conspicuous for their beards. The Taliban decreed that, in accordance with Islam, beards must be grown as long as possible and never trimmed, let alone shaved. Young boys p at their chins, stretching thin hairs as lo as they will go.

The Taliban's moral code is enforced the aptly, if sinisterly, named Ministry of Prevention of Vice and Promotion of Virtue. The ministry's agents roar around town in expensive four-wheel drive vehicles, jumping out to set upon and often to beat up men and women who have offended Taliban codes. Men whose beards are thin and straggly are at risk, as are women if they sho ankle below their burqas. Women's as that are deemed "squeaky" are banned; s are white socks. Each is considered sexua ly provocative. Women, say the Talibai "must walk softly at all times."

(18) he Taliban is an unexpected an extraordinary byproduct of the $\mathrm{Col}$ War. After the Soviet Union invader Afghanistan in 1979, the United States an other Western powers financed an equipped the jihad, or holy war, against th infidel invaders. Many of the Taliban art 
the progeny of the Atghan retugee camps and religious schools set up in Pakistan in the 1980 s. At first they were disciples of the mujaheddin fighters financed by the CIA and the Pakistani intelligence agency to drive out the Soviets. But the withdrawal of Moscow's troops in 1989 did not mean the end of outside interventions in Afghanistan.

On the contrary, more and more arms were pumped in by Pakistan, Russia and Iran. The mujaheddin seized Kabul in April 1992, but the civil war grew fiercer and fiercer. In the south, religious students became increasingly disillusioned with the corruption of the mujaheddin, the warlord ism and the breakdown of society. "They saw themselves as the cleansers and purifiers of a guerrilla war gone astray, a social especially |system gone wrong and in education an Islamic way of life that in been compromised where mixing by corruption," wrote the sexes Ahned Rashid, a Paki paves the stan-based journalist, in way for his recent study of the adultery. BBC World Service $12 / 30$ Taliban.

The group's structure and decision-making process are virtually unknown. They are led by an unseen man named Mullah Mohammed

Omar. He is said to be tall, about 40 years old, from a poor farming family. Omar is reported to have a long black beard (of course) and to be very devout. "We took up arms to achieve the aims of the Afghan jihad and to save our people from further suffering at the hands of the so-called mujaheddin," he said in one of the only two interviews he has ever given.

Since its earliest days, the Taliban movement has been closely linked with the fundamentalist Islamic parties in Pakistan and have recruited Pakistanis to serve in it. The Taliban forces also developed close, complicated and often covert links within different parts of the divided Pakistani power structure, including the Pakistani transportation mafia

Pakistani truckers had long enjoyed and exploited smuggling routes from Pakistan up through Afghanistan to Iran and Central Asia. In the 1980s, the civil war, and the division of Afghanistan into clashing fiefdoms, dislocated their business. As the Taliban grew in strength in the mid-1990s, it allowed Pakistani truckers to extend their routes and their profits, while the Taliban increased its tolls. The truckers were also carrying heroin toward the lucrative northern and western markets. Religion and smuggling have made fine bedfellows.

B y 1995, thousands of Pakistani and Afghan students had rallied to the cause of the Taliban. They captured

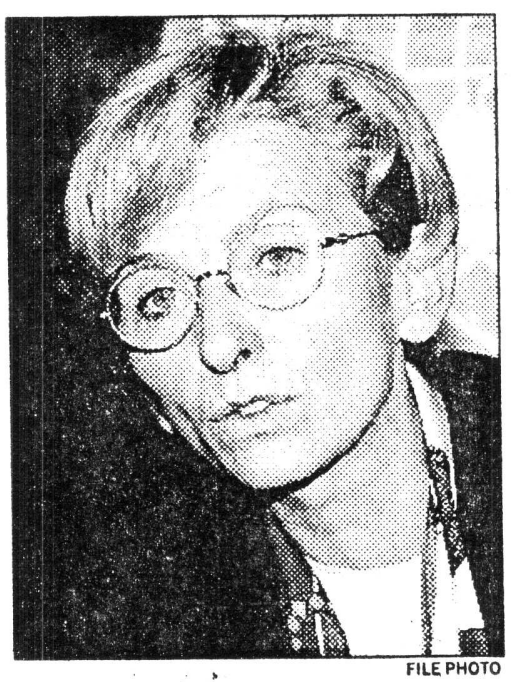

Bonino, detained.

\section{Camera-Shy in Afghanistan}

- Things got dicey yesterday in war-torn Afghanistan for CNN reporter Christiane Amanpour, Emma Bonino, the European Union's top humanitarian aid official; and 18 others who were held for three hours by the Taliban militia, the Associated Press reported.

It seems the visitors were at a Kabul hospital when they broke the Islamic force's stricture against taking pictures, particularly of women. Four people were filming women there when the Taliban, apparently alerted by a doctor, took the $\mathrm{EU}$ and media group into custody.

Bonino-who oversees $\$ 34.5$ million in aid to Afghanistan- "received apologies" from the Afghan foreign affairs department, an EU spokesman said.

\section{The WAshington POST SEPTEMBer 30, 1997}

the city of Kandahar in southern Afghanistan, and opened more and longer routes for the truckers.

Afghanistan's neighbors became more and more nervous. The Russians saw the Taliban forces as intent on military and fundamentalist expansion into Central Asia. The Iranians saw them as stooges of Saudi Arabia and the United States, attempting to encircle and weaken Iran. When the Taliban captured Kabul in September 1996, both Russia and Iran reacted with horror. "This is a disaster and we strongly regret it," said Iran's president at the time, Ali Akbar Hashemi Rafsanjani.

The Taliban still enjoys assistance from Pakistan, Saudi Arabia and the drug market. In 1996, Afghanistan is said to have produced well over 2,000 metric tons of opium. One calculation is that the market is worth some $\$ 7$ billion-and of that, some $\$ 70$ million goes to Afghan farmers. Taliban officials say that the production cannot be stopped unless a crop substitution program is set up and paid for. They claim that 200,000 families depend on the production of poppies and opium for their livelihood.

The opium trade does not help the citizens of Kabul. About 250,000 people of the city's 1 million people are dependent on food handouts from the United Nations and other international agencies, including the European Union (EU), the largest single donor. Such aid is vital to the population, but it also undoubtedly helps sustain the Taliban.

I was in Kabul with Emma Bonino, the EU commissioner for humanitarian affairs, who was visiting aid projects that her office funds. The Taliban had just decreed that no women could be treated in any hospital where men were present, either as patients or staff. Female patients were being moved to a facility where there was inadequate water, electricity and equipment: Bonino, a feisty person at the most quiet of times, was infuriated by this latest assault on women's rights. She insisted on visiting the new women's clinic, and she took with her a French camera crew, a CNN camera crew and a number of foreign aid workers resid. ing in Kabul. Not surprisingly, the hospital's female director panicked at the thought of what might happen to her if she allowed our visit. She called the Taliban police.

They arrived in a maroon truck. Using their Kalashnikov rifles as truncheons, they herded us all off to the central police station where we waited several hours sitting under a tree on a carpeted platform where policemen usually sleep.

Eventually, a minister of health negotiat: ed our release. In one of those feats of modern technological wizardry that the Taliban abhors, Bonino was immediately interviewed by CNN on a satellite link. She said she had experienced a little of the random terror that the people of Kabul suffer every day.

Since then, Bonino has made the "gen:der genocide" practiced by the Taliban one of her principal causes. She wants the vorld to dedicate the International Wom: n's Day next March 8 to the women of Kabul.

\section{ThE Washington POST}

NovemBer 23, 1997
A study by Belgian doctors found that more people were disabled by polio than landmines in southwestern Afghanistan. (Reuters -11/27). 


\section{Muslims assail Taliban's view of Islam}

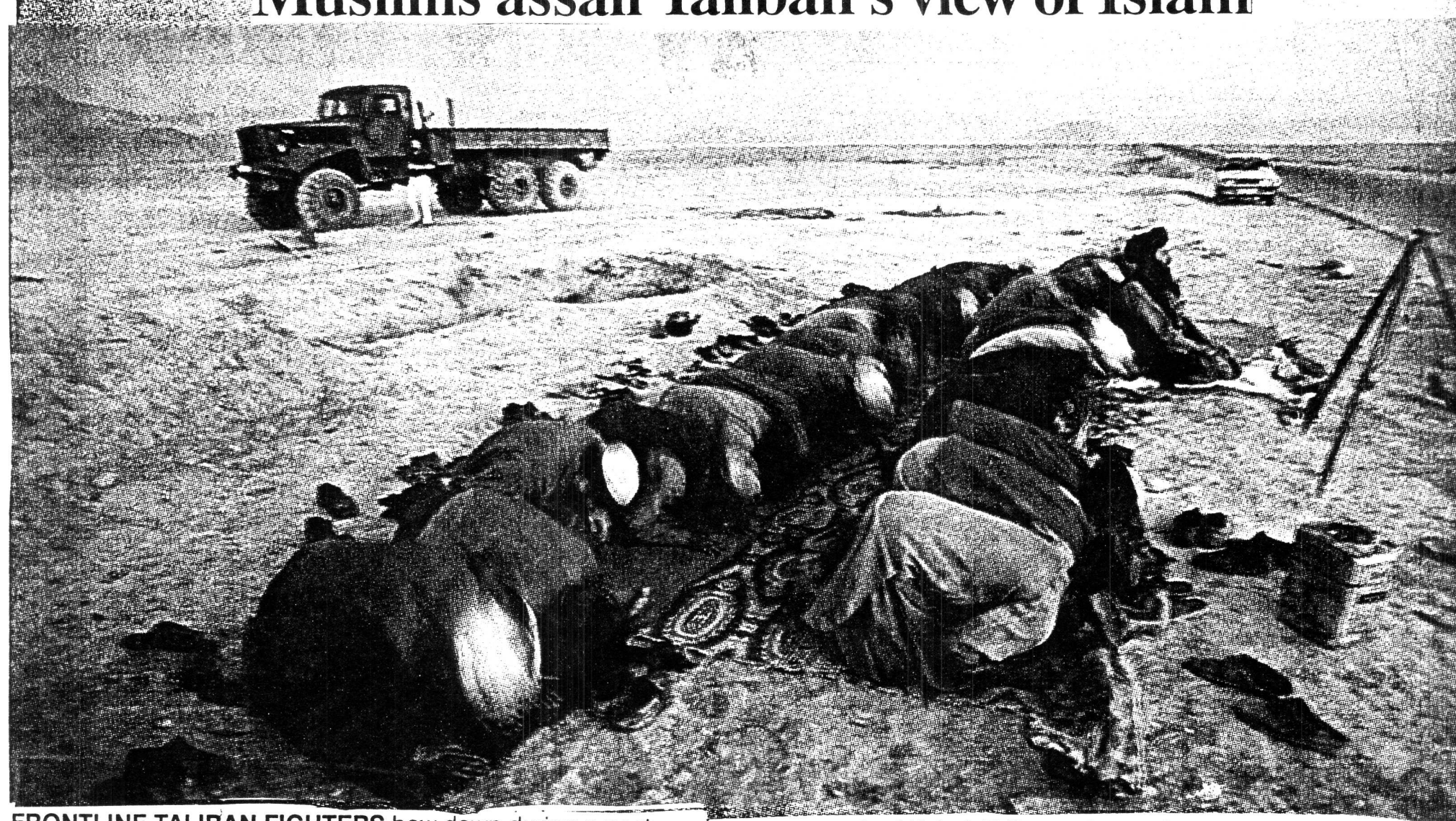

FRONTLINE TALIBAN, FIGHTERS bow down during a post-suns; prayer north of Kabul. Taliban rulers enforce a strict vision of Islam.

\section{By Anthony Shadid}

ASSOCLATED PRESS

KABUL, Afghanistan - In a drumbeat of denunciations, Afghanistan's Taliban rulers are being derided as extremist and dangerous, as backward, as distorters of their faith.

Such attacks have been made before by critics in the secular, indizidualistic West.

But this torrent of protests is coming from activists elsewhere in the Muslim world, from those whose vision of Islam contrasts sharply with the Taliban's dour program that bans most women from working, bars girls from schools, forces men to grow beards and outlaws everything from cassette tapes to paper bags.

"They're giving an extremely bad example of what Islam is supposed to be when it governs life," Azzam Tamimi, an Islamic writer, said in a telephone interview from Amman, Jordan.

"We are all concerned that when Muslims and non-Muslims look at the Taliban movement, they will be shocked, they will be horrified. They will ask, 'Is this Islam?' " he said.

Leaders of the Taliban religious army, which has won control of much of Afghanistan, including Kabul, the capital, seem surprised by the attacks. They say the criticism must be the result of a lack of information about their movement or perhaps a lack of proper understanding of Islamic law.

Mullah Qalamuddin, who heads the religious police force, says any judgment should take into consideration that the Taliban are fighting a war and trying to revive a country and economy devastated by nearly 20 years of conflict. Even then, he insists, every rule is grounded in Islamic teachings.

"We don't worry about the Western world criticizing us," he said in a dingy office, its walls bare. "As for the Muslim world, we know their information about our situation is insufficient."

Qalamuddin's men roam the streets of Kabul, ready to hand out a beating to any woman foolish enough to venture outside without being fully covered and to any man without a turban and flowing beard.

The Taliban consider music unIslamic, although soulful song is at the heart of worship for other Muslims. Paper bags are forbidden because of the possibility - however slim - they were recycled from discarded pages of the Muslim holy book, the Koran. Flying kites and other "frivolous" pastimes are outlawed because they take up time better spent at prayer.
As a political and military force, the Taliban army represents one of today's most successful Islamic movements.

Fed up with the years of factional fighting among groups that ousted a Marxist government, Taliban adherents poured out of the rural religious schools of southern Afghanistan and neighboring Pakistan in 1994 and eventually marched into battered Kabul last September with barely a shot fired.

Df ite recent battlefield reversals to opponents based in the north, the Taliban still control two-thirds of the country, where they have zealously implemented their version of Islamic law.

Many Islamic activists question whether the Taliban's vision goes beyond the strict rule of that law.

"The vision they have is a very primitive society, a backward society with many traditions that are against Islam itself," said Kamal elHelbawi, a spokesman in London for the Muslim Brotherhood, one of the largest and oldest Islamic movements

Often misunderstood in the West, the Islamic movement - whether defined by the Brotherhood in the Arab world, trends in Turkey or Iran's revolutionary clergy - generally has accepted the science and technology 
of the West while rejecting its culture.

At its heart is an attempt to make Islam a modern theology, one that can cope with the challenges of today's world. Some movements have tried to find an Islamic version of democracy or have taken religious obligations of charity to create vast welfare networks in Egypt, the Palestinian territories and Turkey.

Many feel the Taliban have rejected that modern outlook through their obsession with the lengths of beards or how much of a thief's hand should be severed. Islamic scholars have criticized barring women from work, keeping girls out of school and the injunctions against flying kites, playing music or taking pictures.

The Taliban's legal code is based more on age-old tribal law than any conception of Islamic purity, the critics say.

Iran, long the standard bearer of political Islam, has called the Taliban warmongering, extremist and radical. Iranian women, unlike their Afghan counterparts, have the right to vote, to work and to hold seats in Parliament.

The Times (San Francisco)

\section{Afghans step softly as diplomats debate deadly land mines}

\section{By ANTHONY SHADID ASSOCLATED PRESS}

KABUL, Afghanistan - The path was well-trodden, the farm believed clear of mines. Then he heard thunder, felt himself suspended in the air, and saw his shredded right leg lying lifeless in the dust.

Zemarai, an Afghan land mine surveyor, recalled that day three years ago when he stepped on a land mine. His first thought, he said, was of his remaining leg.

"It was bloody and it was injured, but it was there," he said Wednesday.

Zemarai, who like many Afghans uses only one name, still works in the minefields. The four other men on his team also have lost parts of their legs trying to find and disarm some of the millions of mines buried during nearly 20 years of Soviet occupation and civil war in Afghanistan.

About 280 surveyors work for the U.N. mine-clearing project in Afghanistan. One is injured or killed every week.

In Norway, about 400 delegates from 100 nations are gathered for three weeks of talks to draft an in-
From the San Francisco Tri-Valley Herald, 9/5:

Murder sentence: A man involved in the murder of a convenience store clerk in Oakland more than five years ago was sentenced Thursday to 15 years to life in state prison. Keith Darian Jones. 37, pleaded no coniest in July and was found guilty of second-degree murder in the March 1992 death of 42year-old Hakim Karimi, a Hayward father of three who had fled Afghanistan's political strife two years earlier.

Police said Jones and two other men accosted Karimi after the clerk checked the gas pumps outside the convenience store at 6211 San Pablo Ave. The bandits forced Karimi into the store and stole $\$ 200$ before forcing him to kneel and shooting him in the head.
Copies of the enlarged 2nd edition of Afghanistan - The Great Game Revisited. the standard comprehensive reference study of the communist era in Afghanistan, are available in both hard and soft cover at a $10 \%$ discount from Rosanne Klass, editor and co-author.

The revised second edition, published in 1990, contains an additional 35-page chapter on the Geneva Accords - their history and a critical analysis of their content - and an appendix giving the substantive official text of the Accords. plus the official text of the U. S. Statement submitted to the signatories in Geneva by Secretary of State George Schultz. The first edition of the book, published before the Accords were signed and when their terms were still secret, could not include this material.

For further information, contact:

Rosanne Klass, 250 West 82nd Street New York, NY 10024

\section{Landmines kill 12} Afghans everyday

ISLAMABAD (PR')- Afghanistan, where more than 10 millions landmines have been scattered all over the coun- ternational ban on anu-personnes mines. On the front line of that crusade are men like Zemarai, who inch through villages, across farms, along roads and through canals in search of the weapons.

"Whenever we leave our base, we think an enemy is sitting in an ambush waiting to pounce on us," Zamerai said, resting in a Kabul neighborhood that looks a lot like an archaeological dig - its streets overgrown with weeds, its houses little more than rubble.

The estimated toll of mines alod in Afghanistan rivals the casualties of many wars - more than 400,000 p ple killed and as many wounded over the years. About 10,000 civilian vehicles have been destroyed, and $\$ 60$ million in livestock have been lost, said Tahsin Disbudak, regional manager of the U.N. mine-clearing office in Kabul.

Everywhere in Kabul, where six square miles of the city are still mined, residents hobble about on crutches.

At Chil Stoon, just outside Kabul, men in camouflage wave metal de- try, is one of the densely-mined countries in the world. The landmines killed or maim 10 to 12 Afghans including innocent women and children somewhere in Afghanistan everyday.

According to a recent survey there were more than 425 people injured or killed by mines and UXOs in Kabul city from May 1996 to April 1997. Children accounted for approximately 50) per cent of all mine victims and roughly 85 per cent of all UXO victims. It is very unfortunate to know that about 50 per cent of the landmine victims lose their lives due to lack of medical facilities. Not only this, the presence of mines has also seriously affected the rehabilitation process of Afghanistan. Nation (Pakistan) $8 / 22$

tectors over rocky soil and scrub brush. Clear areas are marked with white rocks, dangerous ones with red.

They map the terrain in a notebook using the tools oi the trade: a compass, measuring tape and a minedetecting dog. ...

The surveyors earn about $\$ 300$ a month - a fortune in a country where a doctor might earn just $\$ 40$ a month. But they and others involved in mine clearance say they will work for free if they have to.

"It shows they're not just working for money," said Sayed Aqa, who directs the surveyors. "They have a commitment to do the job."

THE TIMES 


\title{
The Embassy That Closed Up
}

\section{and Moved to the Internet}

\author{
By Nora Boustany \\ Washington Post Foreign Service \\ D \\ eputy Foreign Minister Abdullah, \\ a special envoy of beleaguered \\ Afghan President Burhanuddin \\ Rabbani, said he is not opposed to a \\ planned gas pipeline from Turkmenistan \\ via Afghanistan to Pakistan. But he insisted \\ that the route, proposed by Unocal and \\ Delta Oil, be controlled by all groups in \\ Afghanistan, not just "an imposed militia." \\ That meant the Taliban, the Islamic faction \\ that controls two-thirds of the country and \\ has chased Rabbani out of Kabul. \\ Abdullah, who like many Afghans uses \\ only one name, declared during breakfast \\ with Washington Post editors and reporters \\ last Friday that Rabbani supporters have \\ captured "hundreds of Pakistani prisoners \\ fighting alongside the Taliban." He urged \\ Washington to exert pressure on Pakistan to \\ end its support of the Taliban, which he said \\ is financed in part by exiled Saudi \\ fundamentalist Ossama Ben Laden. The \\ world also should heed the threat of \\ narcotics and terronsm, ne warned, ciung \\ U.N. studies saying that 95 percent of \\ Afghanistan's opium production originates in \\ Taliban territory. \\ Abdullah headed his country's delegation \\ to the U.N. General Assembly. He said \\ American officials were told that "Pakistani \\ citizens were caught armed and fighting \\ against us, " but they dismissed Pakistanis' \\ participation as that of civilian zealots joining \\ the Mujaheddin fighters, rather than \\ Pakistani soldiers. "Excuse us, yes, they are \\ volunteers. Let us imagine there are that
}

\section{London Times $\quad 9 / 26$}

BY CHRISTOPHER THOMAS, SOUTH ASIA CORRESPONDENT

\section{Women beggars pay the price of Taleban dogma}

A SMALL foreign bank that gave tiny loans to Afghan women for the purchase of a sewing machine, a goat or to finance some other modest means of livelihood has been thrown out of Afghanistan by the Taleban Islamic militia for promoting "shamelessness" among females.

It is a reminder, a year after the Islamic militia seized Kabul, of the almost medieval society being imposed across much of the country. Thousands of war widows who queue every morning in the capital for beans and oil from foreign charity organisations are testimony to Taleban's savage treatment of women.

The Grameen Bank of Bangladesh has changed the lives of thousands in its own country by giving loans of a few pounds, enabling wonen to become financially self-sufficient by selling milk, clothes and blankets, growing produce for sale or opening tiny village shops. The bank survived opposition from fundamentalist clerics at home, but its modest incursion into Afghanistan brought it face-to-face with the world's most conservative Islamic regime.

"The motive of the bank was to lead Muslims away from Islam," Taleban said, accusing it of being a front organisation of Christian missionaries, an allegation received with derision in Bangladesh, where the bank is hugely popular among poor women and is generally regarded as one of the country's most respected institutions. Few who take a loan ever default. ....

The plight of women is nowhere greater than in Kabul, which has 11,000 war widows. Welfare food centres normally operate only in the winter but this year they stayed open in the summer to prevent starvation. The war widows, who have an average of four children, mostly spend their days begging or working for food.
Living in Afghanistan is like living in a concentration camp. It is not only the women who suffer, but also the men," he said of the strictions enforced by the Islamic group.

Rabbani's ousted government announced here yesterday that it has set up an "online uthorities shut down the embassy here cause of a dispute over its control. Yar (he former charge d affaires, who the Internet is accessible at http://www.afghan-government.com.

The Washington Post (O) , toberi 1.).1997

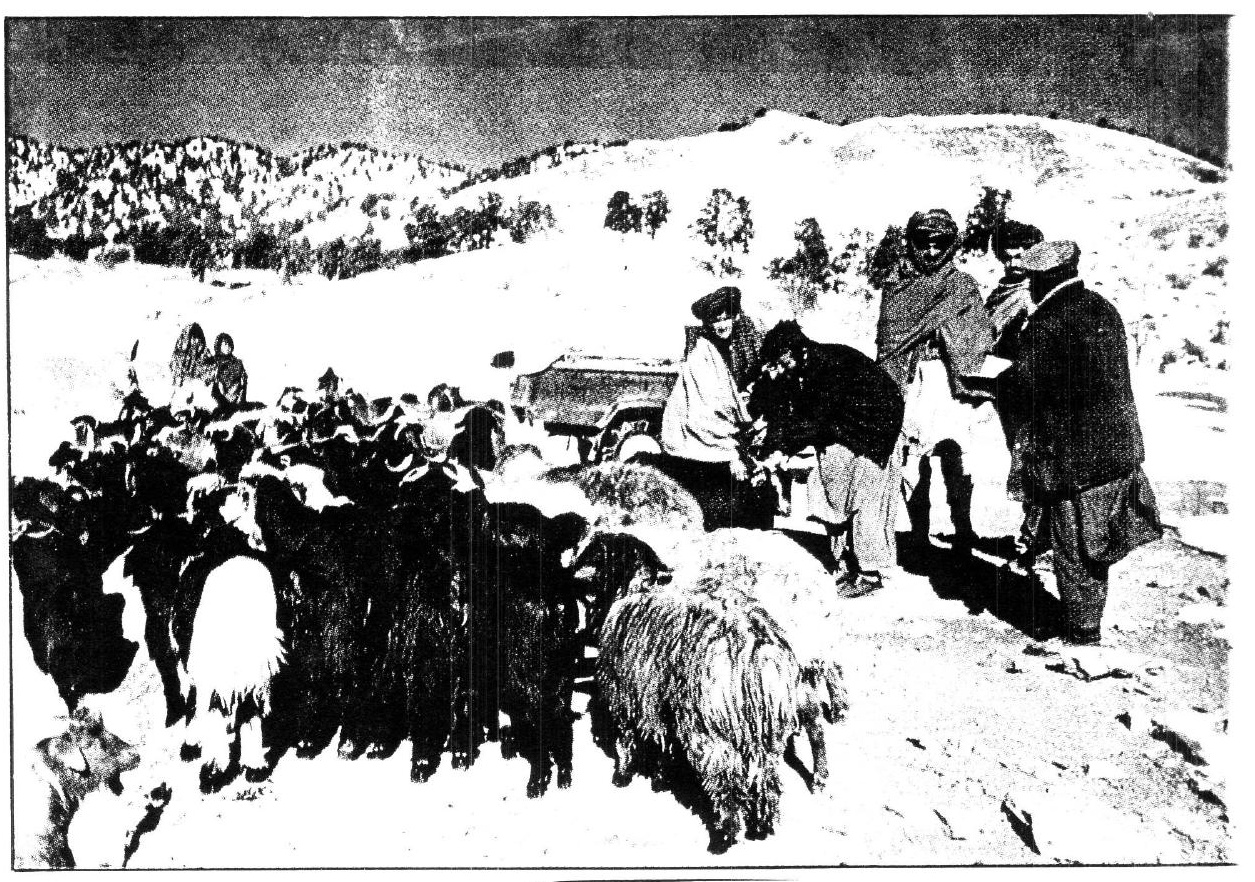

PRB monitor giving technical advice to the livestock owner in Urgoon district, 1

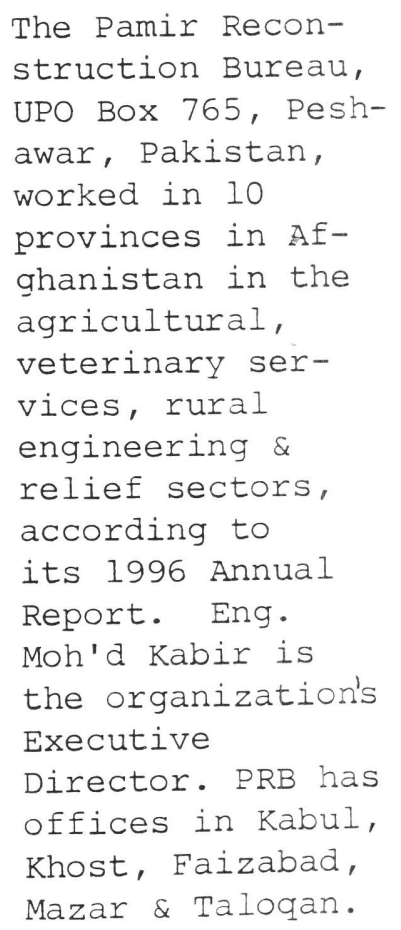




\section{Russia and Afghanistan}

\section{A Unnov}

This article was recently published by Rossiyskaya Gazra, Moscow.

OR centurics the state of F $\Lambda$ fganistan was based on a distinctive and uncepual alliance between Pushtuns and non Pushtums, an alliance which was founded, however, not on violence. Iirst, along with a more or less rigid inter-ethnic hicrarchy at the local level thenghout the country, there existed a considerably more clastic system of relations between clans of different ethuic groups. Sccondly, the major interest of overwhelming majority of $\Lambda$ fghans was to preserve the traditional way of ife inseparably linked with Isiann.

And this impelled the non-Pushtuns to accept inequality as inevit able and somewhat necessary evil. Thirdly, the non-Pushtun groups which sometimes had more complicated relations between thenselves, than with Pushtuns, liad unequal status. If Tajiks held promunent positionis, the Uzbeks did not.

The war which hroke out after the local communists had scized power, dealt a severe blow to the $\wedge$ ghhan unity. The destructin of traditional ties resulted in sharp deterforation of the cthnic factor previously placed decply in the background. Cinsequently, Afghanistan broke into separate, often hostile "quarters". Every such "quarter" being occupied by different cthnic groups, the tone was set by one of them: Uzbeks or Tajiks, or Pushtuns.

In its time, the Sovict Union was successfully interacting with Pushtuns. Their lcading role ensured tranquillity on the Soviet-Afglian border, and even helped to strcugtrertix oppositional P'ushtun nationalism - first in British India and then in Pakistan.
As is known, the official Kabul, while striving for stronger positions annongst native Pushtuns, had never accepted the $\Lambda$ fghan-Pakistan border (the sucecssor of that border between $\Lambda$ fglianistan and the British India which divided Pushtums into two approximately equal parts in the last contury.

Pushtuns who found themselves in the position of a large minntity in l'akisthn, usually used the Afghan stand to strenglhen the is own role in this country. $\Lambda$ t the same timc, the relusal of atuthoritics to satisfy their demands led to several outbreak: of struggle for independent Pushtunistan.

the national question had always been on P'akistan's agenda. Under the pressure of inter-ethnic contradictions, once the country had already' fallen in parts. Therefore in the global Sovict-American confrontation the rolc of the "Pushtun card" was not the lowest. It is not hy chance that Moscow, not W ashington becanc a major sponsor of $\Lambda f-$ ghanistan's economic development

The Soviet Union deviated from the pro-Pushtun policy after the commumist scizure of power in Kabul, and in fact abandencel the sane when the Soviet troops entered $\Lambda \mathrm{f}$ ghanistan. During that period the communuist government triced to lean upon the cthuic minorities in its struggle with Pushtuns

Furthermore, even afier the disintegration of the Sovict Union and the collapse of the communist regime in Kabul, Russia continued to develop relations with the Afghan Uzbeks and 'Tajiks, since Pushtums had lost control over the northern regions bordering on Central $\Lambda$ sia and were placed closer to thic fiontict regions with P'akistan. During the war, millions of Pushoums had settled on the lands of their tribes in Pakistan form- ing a major base of the anticommmmist opposition.

A short-terme efficacy of the Kremlin's non-Pushtum policy becane obvious once it turned out that ncither Tajiks, nor Uzbeks could make the

pivot of the state serving the whole country. Against this hackground, the appearance of the Pushtun Taliban novement, striving for the revival of inter-cthinic unity linked witl Islam, was innortant. Today, the movement controls the majority of the provinces, the Afghan lurknucu border and Kalual. the capital of $\wedge$ fghanistan.

lior some tinte, the objective significance of lablihan was underestimated. Scemingly, this was facilitated by the evident role played by Pakistan in their emergence. In fact, an extremely important aspect was ignored: that by helping (o) remite $\Lambda$ fghanistan, Islamabad was sceking to prevent the reunification of Pushtums on both sides of the $\Lambda$ ghan-l'akistan border. threatcning Pakistan.

By sccuring self-preservation, l'akistan actually contributes (o) such a reality which objectively not only serves islamabad's interests, but also the interests of the Russian Federation, the Central Asian Statcs, and $\Lambda$ fglianistan itself

Therefore, the presently more halaneed attitude of Moseors (c) laliban has decper causes thin simple sitmational neces sity' to recognize the realities For some time the anti-Talih scntiments in Moscow were favoured by somewhat tendentious interpretation of lic gas pipeline project Turkmenistan- $\Lambda$ fghanistanPákistan. Certainly, from lhe viewpoint of the global Soviet-American confrontation, it may seem that the project is detrinucutal on Moscow's positions in Central $\Lambda$ sia. Ilowever, the realitics of to-day, both international and regional, are different in principle

Indeed, Turkmenistan as wcll as other formet Soviet Republics are actively looking for foreign markets, not only through Russia. And the Rus sian Federation should not put obstacles in their ways. The desire to diversify foreign economic ties in the multi-polar world is only natural for any sovereign state.

Besides, after the disinitégration of the USSR, this line docs practically hiclp to stabilize the former Sovict south, with which Russia docs not and; it secms, will not - for a long time - have duly established borders. In this context is just natural that the Russian "Gazprom" has acquired a portion of shares of the proposed gas pipeline, thus be(oming a direct participant of the project. The recent statement by the Russian Foreign Ministry that the Russian Fed cration is not at all against such projects finishes off the point in question.

While appraising the Taliban as a force without which allAfghan unity camnot be achicved, one should not also leave out of reckoning their opponents, particularly the $\Lambda$ fghan Uzbeks who, vicwed as a whole, do not wisls to return to their modest status in the $\Lambda$ fghan inter-ethric hierarchy

Its own role iil restraining the "Pushtun offensive" is now being cudeavored also by Islamabad. Botld the conjplete disintegration of $\Lambda$ ghhinistan (fiaught with spontaneolus reunification of the $A$ fehati and Pakistan Pushtuns) and its consolidation around rigid Pushtum pirot are codially. dangerous for Paksitan. In the latter cventuality the P'uslatu problem will arise, this time at the inter-state level.

$\Lambda$ fat as Russia is concellited considering botll positivelum negative experience of the past, Moscow will most likely seck for an optinial comlina tion of the P'ushtun and ition Puslitum lines in its $\Lambda$ féla policy, and will not at ill sc onc against another. It is pos sible that in the near future ex actly this policy will perntit t add a principally new page t the bong and uncasy histerto relations between Russid $\Lambda$ fglianistan.

The writer is Senio Researcli Worker, Institit of Russian History, Rtissi an Hunanitarias University,

The Musilm (Pakistan) 


\section{Afghan opium farmers ignore ban}

ASSOCIATED PRESS

SHINWAR, Afghanistan - Pulling on the wispy strands of his gray beard, the wizened farmer mutters the only English word he knows - opium - and vows that no one, not Afghanistan's Taliban religious rulers, not the United Nations, will stop him from growing it.

Haji Saif Rahman says his father and his grandfather harvested the blood-red poppies that make heroin before him, and his grandchildren surely will do the same.

"What else should we do?" he asked, pointing his trembling hand in emphasis. "There's no work. There's no business. There's not enough water and there's not enough land. It's our duty to grow it."

After months of pressure by the United Nations and Western countries, the Taliban have prohibited the cultivation of opium poppies, which are grown by 200,000 families in this war-shattered country.
The ban, hinted at last month in a national radio announcement and elaborated on in interviews with Taliban leaders, comes as the United Nations plans a project to find alternatives to producing opium in southern Afghanistan and in the rugged, rocky soil of the eastern district of Shinwar.

The end of the opium harvest would have far-reaching effects on the heroin trade, which has become a mounting problem in the United States and Europe. Afghanistan produces two-fifths of the world's supply and its borders are pre-eminent trafficking routes, according to the United Nations.

But farmers like Rahman dare anyone to make them stop growing the lucrative crop. Opium poppies are planted on one of every 100 acres of Afghanistan's arable land.

Farmers around Shinwar, a flat landscape of poor, dry soil near the Pakistani border, insist that crops like wheat and corn don't grow well here. Even if they did, they say, the money wouldn't be the same as what they earn from a few acres of opium poppies.

Kalender Khan, a 29-year-old farmer whose hands were encrusted with mud from repairing a crumbling wall that borders his plot of land, says he can make $\$ 100$ on his opium harvest

That's eight times what he would make growing corn. And it's a fortune in a country where wrecked villages inhabited only by overturned tanks and burned-ou trucks testify to nearly 20 years of fighting.

The Taliban army took control of the capital, Kabul, a year ago and controls eigh of the 10 provinces where opium poppies are grown.

This year, Afghanistan produced a re cord 2,800 tons of opium - a 25 percen increase over 1996, the U.N. Drug Contro Program said Thursday. Its opium outpu surpassed the combined production of the "Golden Triangle," the jungle region of Burma, Laos and Thailand, it said.

\section{Despite Taliban Vow, Afghan OpiumProduction Is Up, U.N.Says}

\section{By CHRISTOPHER S. WREN}

The Muslim fundamentalist Taliban movement has pledged to crack down on opium poppy cultivation in Afghanistan, but opium production there has jumped by 25 percent over the last year, with almost all of the increase occurring in Taliban-controlled areas, United Nations International Drug Control Program officials said Wednesday.

The United Nations agency's 1997 survey, scheduled for release Thursday, estimates that Afghan opium production rose to about 2,800 metric : tons this year from 2,300 metric tons in 1996. United Nations officials report that Afghanistan now produces the raw ingredient for nearly half of the world's heroin.

Last year, Afghanistan ranked second to Myanmar, which produced 2,500 metric tons of opium, according to a State Department estimate.

Pino Arlacchi, executive director of the United Nations International Drug Control Program, said the increase could mean more heroin flowing into Europe at cheaper prices. European heroin users consume about 80 percent of the heroin refined from opium grown in Afghanistan. Part of the remainder reaches the American market, which is dominated by heroin from Colombia and Southeast Asia.

SEPTEMBER 11, 1997
A United States counterdrug official in Washington expressed no surprise at the United Nations estimate of Afghanistan's opium crop. "Production has skyrocketed, we know that, and production is sanctioned by the Taliban," the official said.

Officials say the Taliban, which has seized power in 22 of Afghanistan's 32 provinces, now controls 96 percent of its poppy-growing areas.

The increase resulted from higher poppy yields, which were attributed to favorable weather, improved cultivation techniques and the shifting of some farmland to poppy cultivation. The total number of acres under poppy cultivation increased by only 2.8 percent, the survey estimated. United Nations survey teams based their estimate on visits to 18 provinces.

The report offered fresh evidence that the Taliban has not fulfilled its promises to crack down on opium production. Taliban officials say they cannot stop peasants from growing opium poppies without other crops to substitute, and contend that persuading them to switch depends on economic assistance from the international community.

The United States and many other countries have kept the Taliban at arm's length because of its violent rise to power and repressive policies like the relegation of women to inferior status. But international officials and journalists traveling in Af-

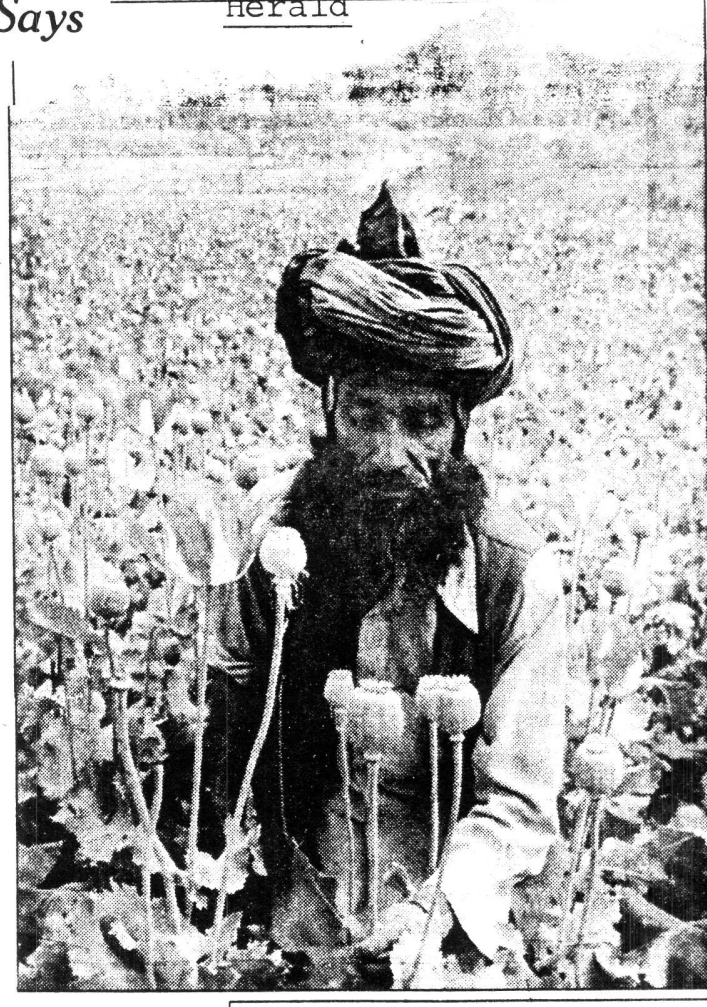

ghanistan reported that the Taliban is not just tolerating opium production but also taxing it for desperately needed revenue and that Taliban $\mathrm{mi}$ litiamen have been seen guarding opium warehouses and helping transport the crop

Taliban officials, while denying any involvement in the opium trade, concede that it is flourishing. : . THE NEW YORK TIMES
A farmer harvests opium in Chapliar, Afghanistan. This area is one of the world's biggest source of raw opium. 


\section{Joining With the Taliban In a New War on Drugs}

\author{
BY RAYMOND BONNER
}

LASHKARGAH , Afghanistan

7 HIS grim, remote town is the capital of Helmand province, the opium-growing capital of the world.

Once dubbed Little America because of all the aid workers here, the province is now controlled by the Taliban, the Islamic fundamentalist movement that forces men to grow beards and women to stay at home, amputates the hands of thieves, and strips tape from cassettes because music is considered evil.

The Taliban has been widely condemned for autocratic conduct and has been accused of providing a safe haven, and training camps, for terrorists.

But last week, the new head of the United Nations' drug-control agency sat down with Taliban leaders and offered them economic assistance. The reason: the group's religious strictures ban drugs of any kind, and it has declared its intention to stamp out the cultivation of opium poppy, the băse for heroin.

Western democracies, which got into bed with unsavory regimes to fight Communism, are now finding allies who are rather unpleasant - and unreliable - in the war on drugs.

The United Nations and its top drug fighter, Pino Arlacchi, need the Taliban to meet a publicly declared goal of eliminating drugs around the world within a decade. No one doubts that Mr. Arlacchi's vision is audacious. But this serious, energetic Italian academicturned-politician has been asked if he is not also naïve. After all, more drug battles have been lost than won. Latin Americla, for example, is littered with the remains

NEW YORK TIMES

NOVEMBER 30, 1997



of well-intentioned projects to wean peasants off growing coca. Unlike their coca-growing counterparts in Latin America, however, Afghan farmers do not have a long history of harvesting poppy. Twenty-five years ago, poppy production here was 200 tons; last year, it was 2,800 tons

So Mr. Arlacchi is convinced he can succeed. Twenty years ago, he noted, opium was grown in just about every country across Asia, from Turkey to Thailand. Now, he said, the war can be concentrated on just two countries, Afghanistan and Burma; together they account for 90 percent of the world's opium supply.

Mr. Arlacchi has begun here, where the Taliban's militancy works in his favor. The Taliban's religious fervor clashes, however, with a secular reality - opium poppy has been a major source of their income. And there is widespread skepticism among American officials and United Nations diplomats over which will win out.

But even the skeptics think it is worth testing the Taliban, which controls 90 percent of the poppy-growing areas of the country.

Western governments will also be tested because the poppy-eradication project is going to cost at least $\$ 25$ million a year for 10 years in Afghanistan. For at the core of Mr. Arlacchi's program are alternative development projects. Give farmers the means to grow crops other than poppy, the theory goes, and they will become lawabiding citizens.

Will Congress contribute America's share for a United Nations project? With the money going to the Taliban, liberal human rights activists might unite with conservatives to oppose the spending. Anticipating problems, Mr. Arlacchi is assembling what he calls a "council of wise men," prominent world leaders from government, industry and the arts, to help him raise money.

It was only after the Soviet invasion of Afghanistan in 1979 that amber fields of grain gave way to bright fields of poppy.

As the country sank into war, everything fell into disrepair, from tractors to irrigation systems; fertilizer and seeds have been hard to come by. So farmers turned from wheat, melons, cotton and their traditional crops to poppy, which is labor intensive but yields more dollars per acre than traditional crops.

Last year, for example, a 60-year-old local farmer named Agha Mohammad planted 14.5 acres in poppy. For his harvest, he was paid $\$ 7,920$ by drug smugglers. So this year, he is planting three more acres, he explained last week as three of his small sons chased away birds trying to feast on the newly sown poppy seeds.

Mr. Mohammad, who has a long snow white beard, is a tenant farmer. The land owner, Hazad Mohammad, said he took in $\$ 16,528$ last year from growing poppy.

In a country where the per capita income is $\$ 100$ a year, it is not easy to imagine that these men would give up this revenue source. But both men insisted they would.

"We are only growing opium to support our families," said Mr. Mohammad, whose family numbers 23. "If we can be assured of irrigation water, we'll cultivate the crops we did before the war."

On the edge of the field is a small canal. It is a channel of the Boghra irrigation system, which was built in the 1960's with American aid money. It is an impres-

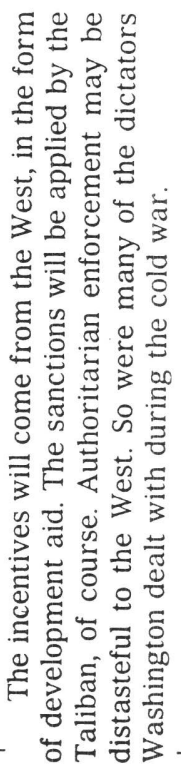



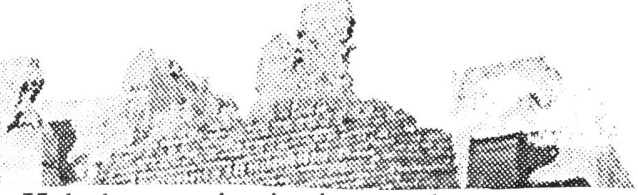

In Kabul, street justice is me ted out by a Taliban fighter

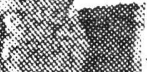
who arrests a man found with 1.1 pounds of opium.

Stretching for 40 miles through flat, desert land, the main canal passes low, thick mud-walled houses se among orchards and small vegetable plots. Green shoots sprout in the plots that get water; camels and donkeys wander in the fields.

Before the war, the canal's waters irrigated 61,000 acres, making this region the bread basket of Afghanistan. Now the canal is filled with 15 years of silt, and most of the water-control gates are rusted.

The irrigation system can be repaired so that farmcan again grow wheat, onions, and apples. But then rug traffickers will still be able to offer the farmers two three times as much for poppy.

Whe we nalked from poppy field. 


\section{Iran's high profile in Afghanistan}

\section{A. Siddique}

A fier some climadtic events following in rapid secession, the Afghan scene is currently marked by a eerie stalemate. After recoiling hack to the outer perimeter. of Kabul's defensive position, the Taliban haye been able to attain the semblance of a tenuous foothold in the face of escalating military pressure.: Ahmed Shah Masud's penchant for exploiting any fleeting window of opportunity, duly supported by his rejuvenated military musclethanks to the massive infision of military hardware by Iran - enabled him to push the Taliban to:the outskirts of Kabul. The Taliban, seriously weakened by the loss of a major segment of their battle-hardened veterans who were killed or taken prisoner during the recent see-saw of fortunes, are desperately trying to stabilise a situation that has eluded their control since their defeat at Mazar-e-Sharif.

The Taliban's rout Mazar-e-Sharif and their subsequent retreat is a classic example of the changing alliances and shifting loyalties, that are so indigenous to the Afghan character. While the Tuliban's dogmatic inflexibility and lack of experience in diplomatic skills and conduct of statecraft may be major contributors to their misfortunes, there is a definite design in the chaos and madness that surrounds their rise and fall in Northern Afghanistan. A close scrutiny of the chironology of events suggests a pattem indicaling cover manoeuvring, dexterous political manipulations and brazen suppor by extraneous forces which reversed the Taliban's swoop over almost the whole of Afghanistan.

With conmbling of the erstwhile antiTaliban coalition, which had centered around the edifice of Abdul Rashid Dostum's Gilamjam Militia, the scene had undergone a quantitative transformation, lending itself to reshuffling and fora realignment of forces on the chessboard of Afghanistan. The fomidable position of the Uzbek warlord had been eroded by the worsening law and order situation prevailing in areas under his control, the growing resentment amongst his commanders, and the inherent fissures that bedevilled his power base. With the departure of Dostum, the scenario appeared ripe for a Taliban walkover in Northern Afghanistan. This,

While looking in retrospect at the Taliban's debacle, theretis strong evidence to suggest that the massacre of the unsuspecting Taliban in Mazar-e-Sharif, which initiated their reversal, took place in areas which were strongholds of Hizbe Wahdat. Some analy'sts believ'e that encirclement of the Taliban in the uaknown urban terrain of
Mazar and their rout was a well-conceived plan by the W.ahdat's military leadership under the tutelage of extruneous forces. Bashir. Salangi, a local warlord, in an inter. view with the BBC revealed the pluri by the Northern Alliance and its pauons to crush the Taliban in Northern Afghanistan. The situation in central Afghanistan was also well syachronised with the happenings in Mizur. While the Taliban tide rouched its high w'ater mark and was inundating almost entile Afghanistan, Bamian Province, a stronghold of the Hizbe: Wahdat remained defiant as an istand of strong resistance despite having been isolated and coming under sirong pressure from all directions. The fact that the Hizbe Wahdat troops, duly strengthened by the massive Iranian aid stuod their ground and refused to buckle under pressure provided an anvil which was subsequently used by the anti-Taliban Alliance to choke the impetuous Taliban who had heedlessly rushed past Salang. The Taliban who had passed through the bottleneck of Salang, had exposed their vulnerable flanks to attack by Ahmad Shah Masud's forces, which didn't take much timc in materialising. Having been resuscitated by the massive infusion of military hardwyare from Iran, he found the opportunity simply irresistible and prompily severed the Taliban's lines of communications. By' a cleveriy conceived and defily executed stritegy, the Taliban were extensively clobbered by the Iranian proieges at Mazar as well as in areas north of Salang.

Consequently, ever since, the Taliban are on the retreat. They have lost Pul-e-Khumri, Salang Tunnel, Jabal-dis-Saraj, Gulbahar, Ghorband, Charikar, Begram and Qarabagh. With one counter stroke the Taliban have been thrown back to the siluation of October ")6, where alter having captured Kabul on Septeniber 27, they were consolidating their gains in the face of strong pressure by Ahmad Shat: Masud's rivices.

The lurn of lontunes have proved fortuitous for Hizbe Wahdat, who fill recently, had been playing a second fiddle to Dostum's Jumbish-e-Milli. As a conseyncince of llic imbroglio, Jumbish-c-Milli's hold over Northem Alghanistant, as wass the case in Dostum's heyday, has been seriously curtailed. Ilis nemesis, General Malik, hats been politically and militarily margeinalised by the wirn of events. Malik's position is a pale shadow of the authority and cloul wiclded by Dostum, the man whose prolitical mante he hoped to arequire. Ile has not only been forced out of Mazar, but his writ stands curtailed only to Faryab, Jaauzjan, Saripul and Samangan while claiming partial control of Balkh and Baglilan. Consequently, Hizbe Walldat has emerged as the strongest of the factions in Northem Afghanistan thus paving the w'aly for its greater clout in any politico-military dispensation in the coming dalys.

The victory of anti-Taliban forces has been sweelly satisfying for Iran, which hats continued to raise its profile in Alghanist:m to ensure a significant role for its proteges, even at the cost of Balkanisation and at continued fratricidal struggle in Afghanistan. In the pursuit of her national interests, which are being increasingly driven by material ralher than iucological incentives, and her paranoid vision of being isolated and encircled, Iran has apparently heen indaced by. Hhe flux of events on heriastem flank to throw discretion to the winds and apenly come to the aid of the anti-Talibast Alliance. While evolving her design in he atghan jigsaw puzzle, Iramiaus have strongIf focused on elhnic finctors in steel the aliance against predominamtly Pashtun Taliban. In such endeavours Iran has been strengthening the llizhe Wahdat to an extent that in the current fiamework it has become the dominant military power in Afghanistan. In the aftermath of Dostum's departure form the seene, Ilizhd Wahlan, wilh Karim Khalili as its learler, hats heen appointed by Iran to lead the anti-Taliban alliance. Such juxstapositioning has plaved its mentors in the driving seat to strive for solution of the Afghan problem in line wilh llacir perceive whectives in the region regandless of its nightmarish consequences.

In pursuit of their designs, it is obvious 10 Iranians that without the capture of Kabul, the Northern Alliance will continue (o) lack in credibility. To this end the present situat tion oflers lucrative dividends. The Taliban have been convincingly beillen and atura of their invincibility lay's andienticully shat tered. Their milinary imbalance is being at:centuated by the substantial losses amongst their veteran force. Iran is seized with the situation to pursue her objectives to its logical end. She is taking all pessible political and military measures nensure the repuisite material supetiority of the antiTaliban Alliance for a breakthrough in 'e positional warfare. Tothjsend Iranians ha built extensive air bridges to expedite the build-up of forces in their areas of interest. Cargo flights contimue to operate at a steady pace to supply arms and ammmunition, mant. power and other logistic ilcuss (o) ale antiTalihan forces. The'se Mighls, operanting on daily basis, are louch: ing down at Bamiyan, Takhar, Maimana; Badakshan and Mazar-e-Sharit. For supplyiug Masud's forces with the neces: sary wherewithal, Kulyah in Tajikistan is beingused to land supplices. To improve rela live strengll ratio, Iran is alșo training Afghan nationals, especial Inizanis in numerol ciunps established $n$ only along the Ira: Afghan Border h also in the lranian hi terlatid. The: Hazaras lyad foug during the Iran-Iri 
war as pant of lamian Sepah. Ilaving then been de-indacked, llicy have again been recruited to fight along lle llizhe Wahdat Cadres in Afghanistan. A significant number of these troops has already been airlified in Lanian planes for their inducion in operations north of Kabul. To maintain a steady supply of manpower, lian is also known to have launched a recruitment drive amongst the Afghans residing in Iran to join the fight against the Taliban; duly laced with offers of lucrative monetary ricwards.

While Iran is engaged in an overt suppon of the anti-Taliban Alliance, its statcecontrolled media is leading an all-out assiault on Pakistan, blaming it vehemently for supporting the Taliban and perpetrating internecine warfare in Afghanistan. Crilicism of Pakistan in editorials of Iranian media has, by now, become a faniliar feature uf lranian newspapers. If one wete to believe lhe Irat nian press, thousands of Pakistani anmed forces personnel are fighting alungside the Taliban and areeven held as prisoners aloug with some senior officers - a fact which has remained as unsubstantiated as the Iranian claims that many Pithistani planes hall been captured at the Mazar-e-Sharif.

Iran's involvement in the curtent situation in Afghanistan is substantial und hats come to be recognised as a halld ground reality. ller interest in Afghanistan had remained dormant during its occupation by the Russian forces. Its surficting has coincided with the break-up of the Soviet Union ante emergence of the Central Asian Republics. whose untapped reservoris of energy some:es and their transportation (1) energy starved West and lapan offers unprecedented biornomic possibilities to the peripheral states. The lum of events do indicalte dhat piersistent turnoil in Afghanistan may coincide with the Iranian economic and commercial interests in the region. For these interests-Iran is prepared to perpetlate the lurmoil in Afghanistan and take all pos sible measures to resurrect her proteges there, even ilit is at the cost of breaking up the unformale comnty.

Iran's srack record in Afghanistan is indicative of a lop-sided approach to resolve the issue. She is wislifully tent upun wishing awaly the Taliban fiom the Afghan seene, who are in control of more than threcfouthis of the country and atle strongest


ry wherellac naw powerest gun is a latalition al arbiter of dispules. While Pakistani diplomats are in constant louch with all parties on the Afghan scenc, Iramians have poignamily

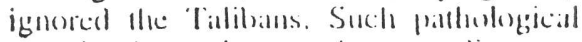
aversion has anly sctred (o) compliciale an -already complex situation. Thinks of the Iranian patronage, the ethnic schisms in Afghanistan are more defined toklay than ever before and the lheat of Balkanistan looms hlucialeningly over Afghanistan. Both Iaın and P'akislan have lẹgitionate concerns in Afghanistan for which the two countries lavelofind a commong ground (o) resolve he problem. It is distuntring to see hat lran at the inoment is single-mindedly pursuing a pol icy which aims at the division of Af phanistan on ethnic lines - a proposition which is loaded with dreadful implications for the region. It is also ironic to see that while Iran is brazenly going full (hroule in suppont of the anti-Tilliban Alliance on bect hem up militarily, her propangandamachinery led by its state-controlled media continues (1) matlign Pakistan for allegenlly supporting the Taliban. It is the proverbial case of the kettle calling the por black.

\section{The Jation '(Pakistan) 9/1}

\section{Inhuman look at animals}

\section{From Nafees Takkar}

KABUL - Two brothers from Panjsher valley once betted between themselves that whoever would touch the lion in the Kabul zoo would be rewarded with money. The daring younger Panjsheri plunged into the enclosure and went upto the beast. "If you are a Sher (lion) so I am Panjsher", he pettud it to his heart's content and the lion's response was cordial. Emboldened, he stepped towards the lioness to touch her also and he did it at the cost of his life. But the moment he touched the lioness, her spouse dashed at the Panjsheri, tearing him to death in no time. The incident occurred in 1993.

This lion is named as Marjan by the zoo staffers and visiting children were listened calling its spouse "Chucha".

The story didn't finish here. Next day, the other brother entered the zoo with a grenade and stealthily threw it inside the lion's enclosure. The poor Marjan took it for a piece of food and as he lowered his mouth to it, the grenade exploded-depriving him of one eye, thanks he survived the attempt on his life. In those days Kabùl was ruled by Ahmad Shah Masood, himself a Panjsheri, and the accused was not punished.

The Kabul zoo and its inmates present a sound reflection of war-ravaged Afghanistan. It is a torn and very basic building hit by bullets, rockets and missiles. The three-floor main portion of the premises has been reduced to only one room which is given to director of the zoo. The rest of the structure is now a skeleton of a one time graceful zoo.

The long civil war also reduced the number of animals from 108 to only 13 during Dr Najeeb's era under Taliban rule. These animals were either killed in the crossfire between the rival forces since 1992 or due to lack of food and unhygienic conditions. Its only elephant was killed in 1994 when the zoo came under severe crossfire between Ahmad Shah Masood and Gulbadin Hekmatyar's forces. Director of the zoo, Abdur Razaq said, a forceful rocket fell near the elephant and the beast blown away.

Out of the two bears, the zoo has now only one. The other one was killed by a Talib in June 1997. It is said that the bear came out of its cage and bat the leg of an elderly staffer. The man narrowly escaped death but lost his leg. However, a Talib on duty shot down the bear with his Kalashnikov. Taliban adininistration, nevertheless, didn't notice the crime and the accused is still at large.

The zoo's living inmates include Marjan, Chucha, monkeys, rabbits, wolf, bear and few hens and cocks. The daily food budget for these animals stands at 150,000 Afghani. The director of the zoo, however, said the budget was not enough to meet the requirements. He was not satisfied with the medical facilities for the zoo inmates.

Recently, an NGO, Sate/ WWF, has promised the zoo authorities to provide them 15 cages and a plan to reconstruct the zoo. The Greek Zoo Authorities have also vowed to provide animals, said the director.

The zoo was established in 1965 by AfghanmonarchZahir's son Ahmad Shah.

Being a lover of animals, he converted a local club into the zoo. The 26-year-old Marjan and Chucha were gifted to the Kabul zoo by the government of Germany. They seem tired and cold. A piece of meat fails to attract them and the staffer often takes it near to their mouth to receive their re? sponse. They hardly roar and once they roar, visitors are really amused as they think it something rare.

The Nation 9/11

\section{MUJADDEDI IN EGYPT}

Sibghatullah Mujaddedi

6 left Peshawar on 11/15

$\rightarrow$ to settle permanently

$\vec{H}$ in Egypt. He had offers

秀 of asylum from 3 count-

苟 ries but chose Egypt as one of his sons is

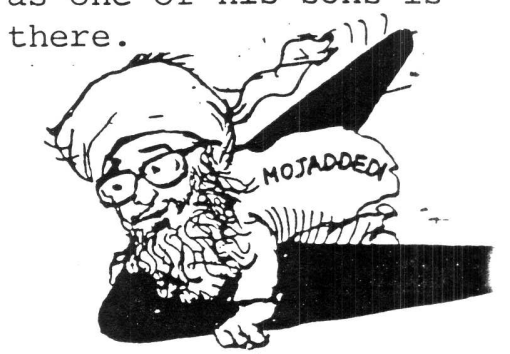




\section{U.S. and Iran Cooperating on Ways to End}

\section{By BARBARA CROSSETTE}

For several months, in low-key meetings at the United Nations that began after Mohammed Khatami took office in August as Iran's first popularly elected President, Iranians and Americans have been working together in a small group of interested nations to explore ways to end the civil war in Afghanistan.

The talks on the Afghan conflict which both countries want to end, though for different reasons - provide not only a rare chance for direct contact between Iran and the United States but also an opportunity to establish some kind of longer-term working relationship between Washington and Mr. Khatami, who offered an olive branch to the United States at a news conference yesterday in Teheran, the Iranian capital.

"We are hopeful that the Iranians will play a constructive role in bringing their influence to bear to see the fighting stop and negotiations begin for the establishment of a broadbased government in Afghanistan," said Karl F. Inderfurth, Assistant Secretary of State for South Asian Affairs, who has been meeting with the Iranians in New York.

The United States, which has isolated Iran since the seizure of the United States Embassy in Teheren in 1979 and the holding of American hostages for more than 15 months, nevertheless has some experience in dealing with Iranians in the United Nations system. On occasion, most recently in arms control negotiations, the Iranians have often been less obstructive than, for instance, India, with which Washington has had a long, unbroken relationship.

Mr. Inderfurth left yesterday for a trip to London, Paris and Moscow to discuss the Afghan problem. He said in an interview on Thursday that since talks began here in the fall that include the United States and Russia as well as Iran and Afghanistan's other neighbors - Turkmenistan, Uzbekistan, Tajikistan, Pakistan and China - other nations had shown an interest in joining in, signaling their hopes that progress can be made.

The talks at the United Nations, led by Lakhdar Brahimi, a former Algerian Foreign Minister who is Secretary General Kofi Annan's special envoy on Afghanistan, are focused on how to bring the militant Taliban movement, which has taken control of more than 80 percent of Afghanistan, into power-sharing negotiations with a group of allied warlords in the north of the country.
Although the Taliban are devoutly Islamic, they are ethnic Pathans and Sunni Muslims. The Iranians, who are Persian-speaking Shiite Muslims, have supported one of the groups resisting the Taliban, the ethnic Hazara Shiites' Hizbe Wahdat Party.

The United States has withheld recognition of the Taliban, criticizing their human rights record, especially their treatment of women, and their unwillingness to compromise with other Afghan ethnic groups. American oil companies are interested in developing gas and oil pipelines from Central Asia to Pakistan or the Arabian Sea through Afghanistan, but they have been advised that finding financing will be difficult with a war going on and no functioning central government in Kabul.

The United States now seems prepared to put pressure on the Taliban movement, to push it toward a political settlement that would allow it to be recognized internationally.

Taliban leaders have been encouraged to visit the United States. The first delegation just completed a tour sponsored by Unocal, the Californiabased oil company that is a major partner in Centgas, one of two international consortiums bidding to build pipelines in Afghanistan.

The Taliban delegation met in Washington with Mr. Inderfurth and other American officials and also visited the University of Nebraska at Omaha, which is setting up technical training programs in Afghanistan with a $\$ 900,000$ Unocal grant. Before Communist governments came to power in Afghanistan in the 1970's, culminating in the 1979 Soviet intervention, the United States played a major role in Afghan development.

Mr. Inderfurth said he hoped that the 'Taliban officials visiting the United States were "getting a more realistic sense of the view of the United States, about our desire to play a contructive role in ending the conflict in Afghanistan."

"But they can't have it all," he said. "They will need to work out arrangements so that the legitimate interests of the other groups are tak en into account."

Iran, with its history of anti-Com? munism, has competing commercial interests in the region, including plans for its own pipelines from Cen. tral Asia. But a war next door in Afghanistan that neither side seems capable of winning soon does noi provide the climate for much confi-

\section{Afghan War:}

dence in Iran either. Iranians would: also like to see nearly two million Afghan refugees return homerse

In taking a more active role in. looking for solutions in Afghanistan, : the Clinton Administration appears: to be taking advantage of a conflư-: ence of events that may provide the: best opportunity in years to stop the : destructive cycle of civil wars.

First, there is a widely held opin: ion that the Taliban have advanced * as far as is likely in their attempt tọ : conquer the country.

Robert B. Oakley, a visiting fellow : at the National Defense University: and a former Ambassador to Paki stan, says time is not on the Tali ban's side.

"The Talibán are never going to bę" strong enough - given the geograph ic problems, the ethnic problems and : the military problems - to conquer? the entire country," Mr. Oakley said " in an interview. "The Shiites have " become a very strong movement ifl : the past two years because they have : been fighting hard against the Taliban and because the Iranians have given them a tremendous amount of . support."

A second factor is the politics of the region. In Pakistan, months of political turmoil have just ended, : leaving Prime Minister Nawaz Shà? rif strong enough to turn his atten: tion to neighboring Afghanistan. $\mathrm{Pa}$ kistan has tended to support the Tali ban unconditionally, a position Wash: ington is urging it to reconsider.

Mr. Inderfurth's role is also impor tant, experts say. The third-ranking official in the mission to the United Nations when Madeline K. Albright was the American representative there, Mr. Inderfurth is known to have the confidence of Ms. Albright now Secretary of State, and is ex: pected to have considerable author: ity for policy in the region.

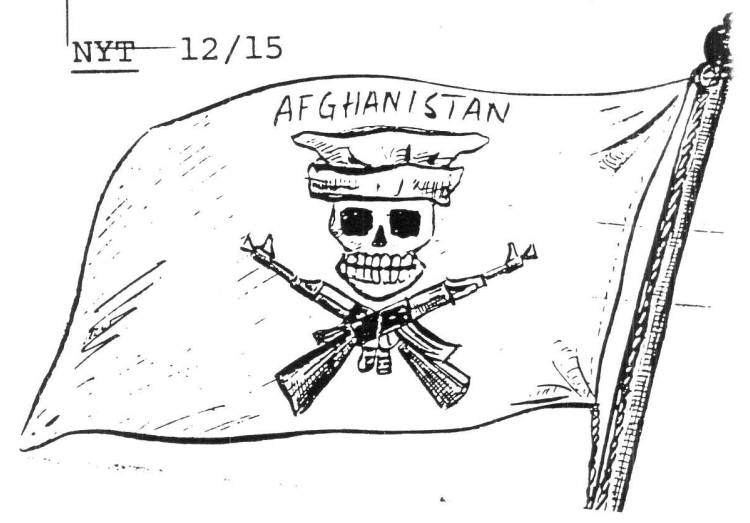




\section{U.S. Turns to Pakistan for Help In Resolving Afghan Civil War}

By RAYMOND BONNER

ISLAMABAD, Pakistan - In the last two months, three senior State Department officials have visited here - the Assistant Secretary of State for Asia, the Under Secretary of State for Political Affairs, and Secretary of State Madeleine K. Albright herself.

Rarely has this country had so much high-level attention from Washington. President Clinton is scheduled to come in the spring, the first visit by an American President in 30 years.

One thing high on the Americans' agenda relates to one of Pakistan's neighbors: Afghanistan.

The Clinton ddministration is putting pressure on Pakistan "very strongly" in the words of one American diplomat - to use its influence on the Taliban, the militant islamic fundamentalists who control two-thirds of Afghanistan, to get them to moderate their behavior and to negotiate an end to the civil war that has raged in Afghanistan since the Soviet withdrawal in 1989.

Reflecting the United States' concern, the Clinton Administration has also been quietly engaged in discussions with Russia and with Afghanistan's six neighbors, diplomats here said. Those neighbors include China and Iran.

The United States' major concerns in Afghanistan are human rights, drugs and terrorism. The Taliban treat women harshly, denying them the right to work or to attend school. At the same time, the Taliban tolerate training camps for terrorists and

THE NEW YORK TIMES poppy cultivation - although they said recently they would work to eliminate the poppies, the source of a large share of the world's heroin.

Among the suspected terrorists living in Kandahar, where the Taliban have their headquarters, is Osama bin Ladin, a wealthy man stripped of his Saudi citizenship because of his ties to militant groups.

In a recent interview, the Taliban Governor of Kandahar, Mohammad Hassan, acknowledged that Mr. Ladin was there but answered with a terse "No" when asked if he would be handed over to the United States or any other Government.

The first objective of the so-called Contact Group on Afghanistan - the six neighbors, plus the United States and Russia - is to reduce the external support for the factions in Afghanistan's civil war.

Iran is the major provider of arms and ammunition for the anti-Taliban forces, flying the war matériel into their bases in the mountainous northern part of the country. Other military supplies are sent across the border from Uzbekistan and Tajikistan, with Russia behind this support, European and American officials said.

Several former bitter enemies have formed a shaky alliance to fight the Taliban. One faction is com. manded by Ahmad Shah Massoud, a Tajik, and another by Abdul Rashid Dostum, an Uzbek. A third group consists of ethnic Hazara and Shiite Muslims.

DECEMBER 10, 1997
Unocal, based in El Segundo, California, has said that the project is dependent on peace in Afghanistan and the presence of a stable government. But any pipeline deal also would have to have the support of the Northern Alliance, which largely controls the northern regions bordering Turkmenistan.

The only existing pipeline that taps into Turkmenistan's rich potential goes through Russia, but Turkmenistan shut off the tap earlier this year because the main customer, Ukraine, has not been paying its bills.

Realizing that waiting for a settlement in Afghanistan could delay Turkmenistan's ability to export gas to other buyers, the Turkmenistan government has gone against American wishes and Pakistani interests and begun negotiating the construction of a pipeline to carry its gas across Iran to Turkey.

The threat of increased Iranian influence in the region, as well as of losing a lucrative contract for Unocal, has led the United States to put forth new efforts to solve the Afghan conflict. The fact that the United States is believed to have strong influence over both Dostum and the Taliban may be an important factor in the degree to which such efforts are successful.

Karl F. Inderfurth, assistant secretary of state for South Asian Affairs, told a Senate foreign relations subcommittee soon after the Taliban's most recent setbacks that U.S. officials have talked with Russia, China and four other nations bordering Afghanistan to determine ways to progress toward an accord.

"We do not believe that any side can win a military victory," Inderfurth said. "Instead we would expect only continued bloodshed. In our view all sides must recognize the futility of fighting." 。 - while fighting continues there.

The consortium announced on Oct. 25 by Unocal, includes the government of Turkmenistan, Saudi

Arabia's Delta Petroleum Corp., Russia's Gazprom gas monopoly, as well as several Asian companies.

Under the agreement, construction of the more than 600mile pipeline is to start early next

year, though this still looks unlikely. through Afghanistan, but construction is all but impossible economic ties, best symbolized by the Unocal pipeline deal.

The pipeline must go 


\section{Taliban tout order in Kabul, but some question the price}

\section{By Anthony Shadid ASSOCLATED PRESS}

- KABUL, Afghanistan - Take away the turban, the worry beads and the flowing beard streaked with gray, and Mullah Abbas might be an American politician on the campaign trail.

"In the streets, the market and the city, there's peace and there's security," said Abbas, one of the leaders of Afghanistan's Taliban religious army. "Your life and your house are safe."

One year after thousands of Taliban fighters fired by faith rolled into the battered capital of Kabul, law and order is the record on which the army's leaders want to be judged.

But beneath the veneer of security run questions about whose law is being enforced, and about the costs of rigid order.

While the Taliban point to residents who can walk the streets without fear of being robbed, their critics - at least, those not afraid to speak out - talk of the loss of other kinds of freedom.

The dread of dying in war, meanwhile, has yielded to the misery of trying to make a pittance to buy a day's supply of nan, the flat bread that is a staple of every Kabul family.

The distress has forced even traffic policemen to beg for money at intersections.

"Why shouldn't I beg? My stomach is empty and I'm hungry," said Kalendar, one of those policemen. Many Afghans use one name only.

The Taliban entered Kabul a year ago with barely a shot fired, seizing a city wrecked by factional power struggles.

Once in charge, Taliban leaders promised to disarm the factions, bring peace and security and, most important, impose their strict version of Islamic laws.

Under the Taliban, women were beaten for not cloaking themselves in a head-to-toe shroud known as a burqa. High heels were banned as were cosmetics.

Most women were banned from working outside the home.

Men were told to grow their beards as the Prophet Mohammed did or face lashings and a few days in jail.

In addition, music was declared off limits. At Taliban checkpoints and intersections, glossy ribbons stripped from cassette tapes still flutter from poles in a not-so-subtle warning.

A campaign against corruption and crime brought a semblance of order to a city once so lawless that people were afraid to keep money in their homes or answer their doors at night.
"In each street, along every step, every person with a Kalashnikov rifle said he was president," said Abbas, one of the seven members of the council that now rules the capital.

"At that time, everyone claimed they were the king of Kabul."

The lawlessness has disappeared. Now, residents focus on miserable poverty.

Two-thirds of the city remains uninhabitable, looking more like an archaeological dig than a capital. In street after street, rubble rests uneasily against still-standing walls and doorways; abandoned homes are overgrown with weeds.

The best-paying jobs are those offered by aid agencies: A day shoveling rubble earns 15 pounds of flour. More than half of the city of 1 million depends on food handouts.

"When the Taliban came, they said they would give food, they would give work and they would give a salary," said Mohammed, a carpet merchant. "Now they say, 'Ask from God.' "

In the mosques and on radio, the Taliban rarely address the hardship. Their message is moral, not economic: Don't steal. Don't commit adultery. Live the life of a good Muslim.

When pressed on the issue, Taliban leaders say nothing can be done about the economy until the end of the war against a fractious opposiion alliance that rules the northern hird of Afghanistan.

"When the war is over, when here is not a single bullet fired, noney can be spent on education, lealth and other things," said Sher Mohammed Abbas Stanakzai, the leputy foreign minister.

The Taliban have used the war to ustify a campaign of arrests that has argeted the city's Tajik, Uzbek and Jazara minorities.

The Taliban are composed mainly If Pashtuns, the largest ethnic group hat mainly hails from southern tfghanistan. The opposition in the lorth is composed mainly of ethnic ninorities.

Hundreds have been arrested in Jabul the past two months on suslicion of aiding the opposition. Most re released after a few days, someimes after a lashing.

THE TIMES

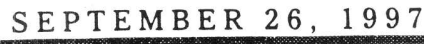

\section{Taleban's success due to 'moral superiority'}

THE military success of the Taleban militia is due to three things, according to an American professor who spent three months in war-ravaged Afghanistan.

The Taleban, with about 80,000 armed men, control about two-thirds of Afghanistan, including its capital, Kabul. 'Of the 80,000 fighters, only about one-quarter are adequately trained and equipped as soldiers.

The Taleban or "students" stunned the world and their military opponents when they emerged in 1994, sweeping through the country, bringing with them their own brand of strict religious observance, including a ban on women holding jobs or men shaving their beards.

The core group of the Taleban are former Koranic students and their mullahs, young teachers of Islamic studies, mostly recuited in Pakistan.

Larry Goodson, an American who is professor at the American University of Cairo, says that the Taleban's initial success was due to the perception that they were morally superior to their corrupt opponents. He spent the summer, dressed in Afghan style, conducting research in Pakistan and Afghanistan.

In addition there was a general war-weariness in a country which has been destroyed by 20 years of ruthless fighting that had turned Afghanistan into a shattered landscape ruled by anarchy and warlords.

That weariness on the part of the battered civilian population tends to favour any side which looks strong enough to put an end to the fighting.

A more important Taleban advantage, Goodson believes, was the training and financial support given them by the Government of Pakistan, through its version of the CIA, the Internal Intelligence Directorate (IID). The Pakistani Government has denied that it is giving military support to the Taleban, but those denials are not taken seriously by American officials.

The Pakistani military gave the Taleban the tecnnical equipment and training that they did not have. In addition, Pakistani advisors gave the Taleban tactical battle training.

Goodson says that both sides in the continuing war exaggerate the extent to which the Pakistanis are helping, the Taleban for prestige purposes. their opponents to demoristrate that they are being outfough because they are being outnum bered and outspent by the Pakistanis.

In addition, there is an ethnic advantage on the side of the Taleban.

They are Pashtun, the largest single tribal group in Afghanistan.

Their opponents are either Tajiks or Uzbeks, minor ethnic groups in Afghanistan. The Pakistani support has much to do with the Taleban's Pashtun roots, since that is the best possibility for Pakistan to try to produce a stable Afghanistan on its own borders.

Despite the Taleban military success, now marked by a few significant reverses in the northern part of the country, Goodson believes that the Taleban, as they now conduct themselves, are incompetent to actually run a country the size of Afghanistan.

In addition, their religious exccesses - carried out by the police known as "Promoters of virtue and piety and suppression of vice" - have alienated the civilian population of Kabul and cost the Taleban any international support they might have picked up in their earlier days.

The religious police arrest or beat any women wearing highheeled shoes or white socks both of which are thought by the Taleban to arouse lustful thoughts in men.

The women must be totally veiled.

The police carry measuring sticks to make sure that men are leaving their beards unshaven.

They conduct painstaking searches for any western or Hindu musical tapes, allowing only tapes which contain readings from the Koran. $-D P A$ 


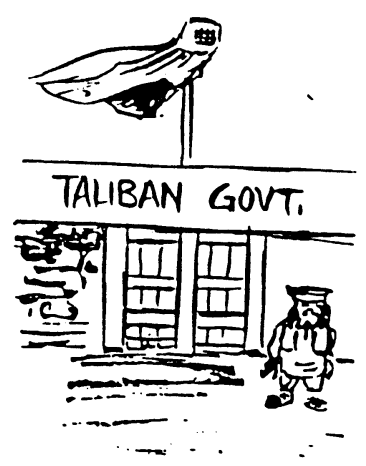

\section{Taliban's Islam}

THE TALIBAN government in Afhanistan gives an impression to the world that according to Islam all sorts of entertainment/ sports, female education, fernale participation in work and other development activities are banned. Especially more than $50 \%$ of female population is meant to be confinedrto the four walls of house.

So far they are declaring various punishment for various activities but have not announced a single welfare and development project in any field. Such trend has brought a bad name to Islam. Will Council of Islarhic Ideology in Islamabad give, its views.

- Maj (R) Sultan Shah Peshawar Cantt.

The Muslim

\section{$8+6$}

Pat Gentner found

a copy of Views

in Afghanistan by

Sir Keith Jackson

in Bartleby's

Bookshop, P.O.

Box 15400, Chevy

Chase, MD.

Published in

London in 1841

by W.H. Allen,

the book is one

of a few copies

"colored as

original

drawings." The

selling price

is $\$ 7,500$; Pat

says the plates

are lovely \& in

good condition

although the

shop states that

this copy may be

missing a

plate \& a map.

\section{Taleban master much of country, not traffic}

By Tim Johnston

Nov 04, 1997

KABUL, Nov 4 (Reuters) - The purist Islamic Taleban may have brought a measure of security to the parts of Afghanistan they control, but they have been unable to tame the country's drivers, residents say

Japanese four-wheel-drive vehicles roar the wrong way up one-way streets in the capital Kabul full of heavily-armed fighters wearing the Taleban's trademark turbans and eyeliner.

The Taleban fly the white flag, a symbol of their mission to purify Afghanistan, but they will not surrender, particularly when it comes to right of way.

There are no rules of the road in Kabul. The novice driver soon learns to forget theories of good driving practice and to give way to vehicles that are larger, faster, or more heavily armed.

Vehicles weave around potholes trying to avoid broken axles, and then have to navigate through overladen bicycles and women wearing the traditional Afghan veil or burqa that leaves only a patch of gauze over the eyes to see out of and, effectively, blocks all peripheral vision.

Traffic policemen in white peaked caps stand at crossroads, waving what resemble red and white table tennis bats in a vain attempt to bring some order to the chaos.

They have become masters of the abrupt pirouette to wave speeding four-wheel drive vehicles ful $\quad$ - - . through a junction without becoming casualties themselves.

Most traffic is military -- dented four-wheel drive vehicles with smoked-glass windows filled to overflowing with fighters.

They share the roads with commercial buses and trucks belching adulterated diesel fumes, taxis, and shiny vehicles belonging to the foreign aid community.

There are few private cars in this city of one million. Hardly any of Kabul's impoverished population can afford to buy a car, or pay for the smuggled fuel sold from plastic containers by the side of the road to run

"You can't expect things to work properly. You have people coming in from the countryside, they don't

know how to drive and their cars are missing pieces like their indicators," says Mullah Bismillah, the head of Kabul's traffic department. But there is a driving test, he says.

"They have two weeks of theory, learning the traffic regulations, not to drive the wrong way up one-way streets and things like that. Of course a candidate has to know how to drive also," said Bismillah.

The already difficult conditions are complicated by lack of traffic signs, most of these having been destroyed in the five-year battle for Kabul.

No traffic lights have worked in the capital since 1992. Bismillah says a traffic department delegation will soon travel to Germany.

"There is a delegation going to Germany to buy traffic lights and other things; they are waiting for the foreign ministry to issue their passports," he says.

But in its own way the war has made a contribution to road safety. The dismal condition of roads makes it virtually impossible in most of Afghanistan to exceed the $50-\mathrm{km}$ per hour (30-milò speed limit.

Qudssia Akhlaque

The News: jang (Opinion) $\quad 12 / 4$

The man on the front line

"They are a ferocious but a lovely lot. They wear high-heeled golden sandals, have painted nails, use eye make-up, and wear big sun glasses with cameras fitted in them." This is how John Simpson, the BBC's World Affairs editor, described the Taliban, "the men that now run Afghanistan". Simpson, who recently returned from Afghanistan, went on: "They are very serious characters, very, very fundamentalist, and they have long beards and are armed with Kalashnikovs."

John Simpson, the BBC's award-winning correspondent, was talking at the Cambridge Union Society about his experiences in the front line of world news and his views on how the BBC needs to adapt for the new millennium. Simpson's description of the Taliban though amusing and technically correct was somewhat disappointing. Disappointing because one expected more from a man reputed as the most experienced foreign correspondent of the world's biggest news gathering organisation. It was disappointing not because one saw it as an attempt on his part to ridicule the Taliban (which was self-evident) but because he did not go beyond the appearance aspect. Instead of explaining the Taliban phenomenon, Simpson chose to humour the audience by painting a image of them as being some outlandish creatures.

Not that one has any sympathies with the Taliban but Simpson's account reflected the tendency of the Western media to trivialise certain issues by looking at them merely at a superficial level. The tendency is to play to the gallery by indulging in little twists that 'sells copy', even at the cost of sensationalising. Result: perpetuating prejudices and stereotypes instead of abandoning them. 


\section{Afghans follow to find poverty across borde}

\section{By Nicholas Goldberg}

Mashad, Iran - Nearly two decades ago, when the fighting started and the food and fuel began to run out, Marziah Hosseini left her home in Bamian, Afghanistan, on a long walk across the war-ravaged desert with her husband and two small children.

For two months they traveled, sleeping on the caked dirt and hiking through the mountains, until at last they came to the Iranian border. Using their remaining money to bribe border guards, they crossed at night, and arrived, finally, at their destination: the holy city of Mashad, where the Ninth-Century Shiite martyr Imam Ali Reza is buried.

"I was so happy that we had reached Imam Reza's soil that I bent down and ate the dirt from the ground," she remembered recently. "At that time, I was pleased to leave our own country, which offered us nothing but bloodshed, fighting, hunger and murder."

That was 16 years ago, two years after the Soviet invasion of Afghanistan, and at that time, Hosseini's path was a well-traveled one: Afghans in long turbans and brightly colored robes - Shiites and Sunnis, children and old men - were all streaming into Iran in search of peace and prosperity. Some traveled over land; some crossed at the river. Some came on donkeys, others by foot, and still others by bus.

But although they came as short-term refugees fleeing the immediate consequences of war, most never went back. To this day, Afghans are the largest group of refugees in the world. About 1.4 million of them still live in Iran, which has the dubious distinction of hosting the largest refugee population in the world. Most of the refugees have no immediate prospect of leaving.

"Many have been there as long as 20 years," said Pierre Bertrand, who runs the Tehran office of the United Nations High Commissioner for Refugees. "Are more still coming? The situation in Afghanistan could further deteriorate so that it would cause another large-scale movement.'

Marziah Hosseini is one of those who remains. In the years of their exile, her husband has died and her children have grown up. Two weeks ago, the entire family could be found in her tiny house in the refugee neighborhood of Ghorghi, shelling pistachios on the floor. For their labors, they earn about 500 Iranian rials per kilogram. Together, they can shell about five or six kilos a day, she says. That means they earn a little more than 60 cents a day. The shells they save for fuel in the stove.

"We were unhappy in Afghanistan and we came here," she said in an interview. "Now we're here. What can we do about it? At least when we're unhappy here, we can go visit Imam Reza."

Another Afghan refugee who stayed in Iran is Ghafour Davoodi, a 55-year-old day laborer who still wears the white turban and robe he wore at home. Each day, he says he's out at 6 a.m. on the streets of Zahedan looking for work. If he gets nothing, he goes home. If he works, he gets 8,000 to 10,000 rials for the day - about $\$ 2$. His rent, he says, is 200,000 rials a month, or a little more than $\$ 40$.

On this particular day, Davoodi has come to $\mathrm{Ma}$ shad seeking assistance for his wife, who needs openheart surgery. If the UN refugee agency will agree to give him money for the operation, she has a 75 percent chance of recovery, according to UN officials and doctors; if not, she will surely die within a few weeks.

Nevertheless, the officials say it is unlıkely they will be able to help because they would have to forgo 10 other operations with a higher probability of success.

Davoodi seems resigned.

"We cannot do anything else," he said. "If you assist us, God will bless you. If not, we will simply return to Zahedan."

When the Afghan refugees first arrived at the border 20 years ago, the Iranians welcomed them. After all, they were fellow Shiites and they spoke virtually the same language. Besides, the Iranian economy was booming and the country desperately needed foreign workers to help out, particularly after the Iran-Iraq war began in 1980 .

In those days, there was a reception center at the border for Afghans. Refugees were given subsidized food and access to health care. They also were allowed to move relatively freely through the country, rather than being segregated in refugee camps. Over time, they spread through the eastern and central provinces and to Tehran.

But in recent years, all that has begun to change. For one thing, when the Iran-Iraq war ended in

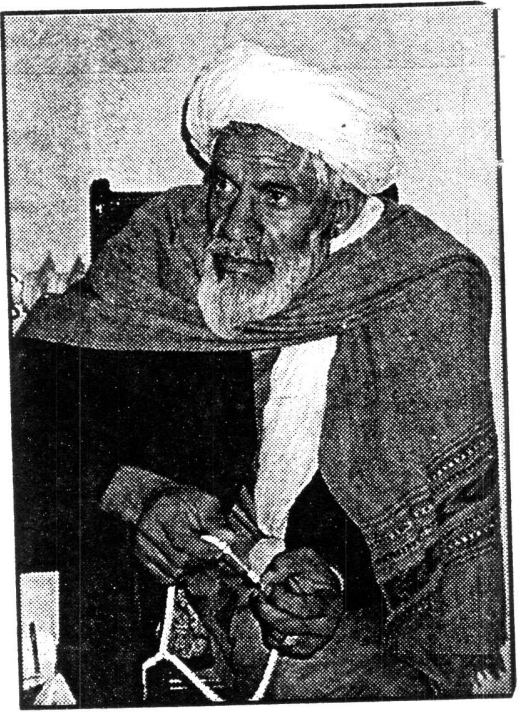

Ghafour Davoodi

1988 and the economy turned downward, Iranians needed the jobs the refugees held. Afghan refugees also shouldered the blame for the spread of drugs like heroin and opium, which come in easily over the border from Afghanistan, where they are grown. In eastern Iran, where the bulk of the refugees live, crime rates increased and the refugees were blamed.

In the early $1990 \mathrm{~s}$, after the Soviet-backed regime fell in Afghanistan, the Iranians began to repatriate the refugees. About 1.3 million Afghans went home. But since the hardline Taliban militia recently took over the bulk of Afghanistan, the repatriation stopped - and a new flow of refugees into Iran has begun.

The Iranian government has recently dug a huge ditch along the Afghan border, ostensibly to deter drug smugglers, but also to stop the flow of thousands of Afghans trying to sneak illegally across the frontier.

Officials have confiscated hundreds of thousands of identification cards from Afghan refugees, making them illegal aliens, without the right to work. About three years ago, the neighborhood of Ghorghi, where Marziah Hosseini lives, was surrounded by security forces and almost all the identification cards were taken away in one night. Today, in Khorazon province, government officials estimate that more than one-third of the 1 million Afghan refugees are illegal.

Although many Afghans still receive certain health services and some schooling, they're generally restricted to the lowest-paying and most hazardous jobs in the country: working in brick kilns and tanneries,

or at chicken farms, pistachı farms, or well-digging sites. They now need permits to travel.

"'There's a fatigue with them," said Roger Viviere, deputy chief of the UNHCR office in Tehran. "Iranians are harsher and tougher against Afghans than they were."

Men who are without identification cards often spend their lives hiding in the house, or sneak out for a dangerous day's work unloading trucks or doing construction or working in the sugar beet fields. If they're caught, they are 


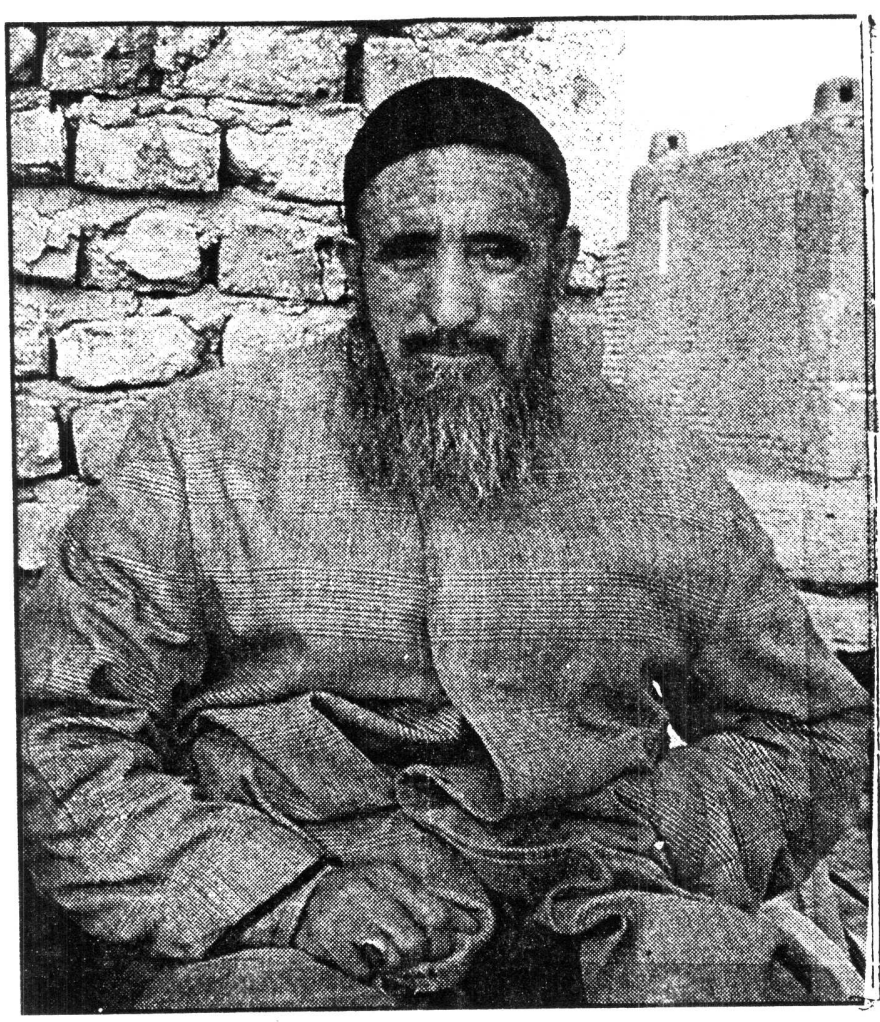

An elderly Afghani refugee in the neighborhood of Ghorghi, outside Iranian city of Mashad. Some have been in Iran for 20 years.

taken to detention camps near the border. To help make ends meet, women and children shell pistachios, clean carpets or make brooms. At 7 or 8 years old, children begin working at construction sites or in the brick kilns. Families are large - typically between seven and nine people - and they subsist on diets primarily of bread, noodles and potatoes and a soup made out of boiled camel hooves or sheep or cow bones.

Doctors and nurses at the local clinic run by Medecins Sans Frontieres, a French not-for-profit group, says it sees infectious diseases, parasites and malnutrition, the consequences of which, the group says, are disastrous. The group also sees, particularly among women, depression and neurological disorders brought on in part by the culture shock of living so far from home. Afghan men beat their wives regularly, doctors say.

Dr. Amirhodi Nojoumian, who works at the clinic, says most of the refugees - particularly the young people, who have been born and raised in Iran and feel little attachment to Afghanistan - do not want to return to a country where conditions are even worse than in Iran, where fighting between rival militias continues and poverty is dire.

"To scare their children and make them obey, the parents threaten them: "If you do not behave, we will go back to Afghanistan,'" he said. "And the children burst into tears."

But the old men, at least, say they wish they could go home.

"I would return if the conflict ended," Davoodi said. "It's our soil. I have no family there, but it's my country. If the decision was with me, I would rather return to Afghanistan, but the situation does not allow it."

\section{Girls'schools}

\section{to be allowed by Taleban}

DDUCATION for girls is being permitted by the hard-

- line Taleban for thousands of rural Afghans hoping to return home from neighbouring Pakistan, a UN official said Saturday.

The official revealed the demands for female education by up to 200,000 repatriation candidates are being met. although the strict Islamic militia maintains a tight ban in the capital Kabul.

"In Pakistan they have electricity, jobs and schools, and when they come back they want the same," Terry Pitzner of the United Nations High Commisionner for Refugees (UNHCR) said.

He said a massive UN initiative, aimed at bringing back around 182,000 refugees from Pakistan to isolated areas in the eastern Afghan province of Nangahar, had been boosted by the Taleban's flexibility.

"They all want girls education, and are all convinced they can get letters from the Taleban allowing it," Pitzner said.

In most parts of the Taleban-held two-thirds of Afghanistan, including the relatively-liberal Kabul, females have been banned from attending work and education under a strict interpretation of Islamic law.

But Pitzner said refugees aiming to return home to rebuild their war-shattered farming communities have greater leverage than city-dwellers recently overrun by the puristMoslem militia that originated in the rural south.

"They invited the Taleban in and if they don't get what they want they will get them out. This gives them leverage," he explained.

He said most candidates interviewed by UNHCR had little concern for the tangled politics of Afghanistan's 17 yearold civil war, and so far had heard few complaints about the Taleban regime.

The reason, he explained, was that few Taleban officials are based in the isolated communities but offer the benefits of better security provided by the militia's clean-up of localised warlords.

In cooperation with other UN aid groups, UNHCR has guaranteed to provide shelter, food for work and other rehabilitation projects as soon as the refugees quit the increasingly inhospitable Pakistan.

But despite the optimism of repatriating the tens of thousands of refugees, Pitzner said up to 210 residents of Kabul continue to leave the city for Pakistan every day.

At least one million refugees who fled Afghanistan after the Soviet invasion in 1979 are currently registered in Pakistan.

Bahrain Tribune - AFP 8 September 1997

\section{NEW IMMIGRATION SPONSORSHIP REQUIREMENT \\ As of 12/19/97, all applications for immigrant visas must be accompanied by an affidavit of support \& documentary evidence of means. (US Dept. of state VISA BULLETIN \#81, Vol. VII. Publication $9514 \quad 11 / 7 / 97$ )}




\section{The Face Behind the Bagel

Afghan Newcomers Use Coffee Carts to Succeed As Vendors of New York's Rush-Hour Breakfast

\section{By MIRTA OJITO}

On his way to work as a supervisor at a downtown deli in the mid-1980's, Fahim Saleh, an Afghan refugee with an easy smile, would buy coffee from a chatty Greek vendor in a pushcart at Lexington Avenue and 43d Street. Mr. Saleh had fled Afghanistan in 1980 and, while he liked his job at the deli, he wanted something to call his own. Like a business.

He dreamed of opening his own restaurant, but finances got in the way. Then Mr. Saleh learned that his new friend made a comfortable living selling coffee and bagels from his pushcart. Mr. Saleh liked the hours, 3 A.M. to 11 A.M., and the independence - working alone in a small space, no boss hovering over the coffee machine. He found a dilapidated pushcart for $\$ 600$, spent another $\$ 500$ fixing it up and, 10 years ago this month, parked it at Lexington Avenue and 41st Street For four weeks, he barely covered expenses.

Since then, with the proceeds from the pushcart, $\mathrm{Mr}$ Saleh has supported his growing family - his oldest child is 16 and his youngest is $4-$ and brought to the United States his five siblings, his parents and even his grandparents. Two brothers, Ali and Bashir, now own their own pushcarts.

By his own account, Mr. Saleh was the first Afghan in New York City to own a coffee and bagels

pushcart, one of the small tin kiosks that in the last five years have sprung up from the tip of Manhattan to the far-reaching corners of the Bronx, wherever major subway exits or large office or government buildings deliver a steady supply of hungry customers.

In the mad rush from apartment to subway to the office, the coffee vendor's face is often the first face New Yorkers focus on every morning. Yet New Yorkers know very little about the person behind the counter, except that the steaming cup of coffee is delivered quickly and often with a smile.

The coffee cart business, Mr. Saleh and others agree, originated with Greek food vendors more than a decade ago. making fresh coffee. From A.M. to $2: 30$ P.M., he rare leaves his tw square feet 0 : work space.

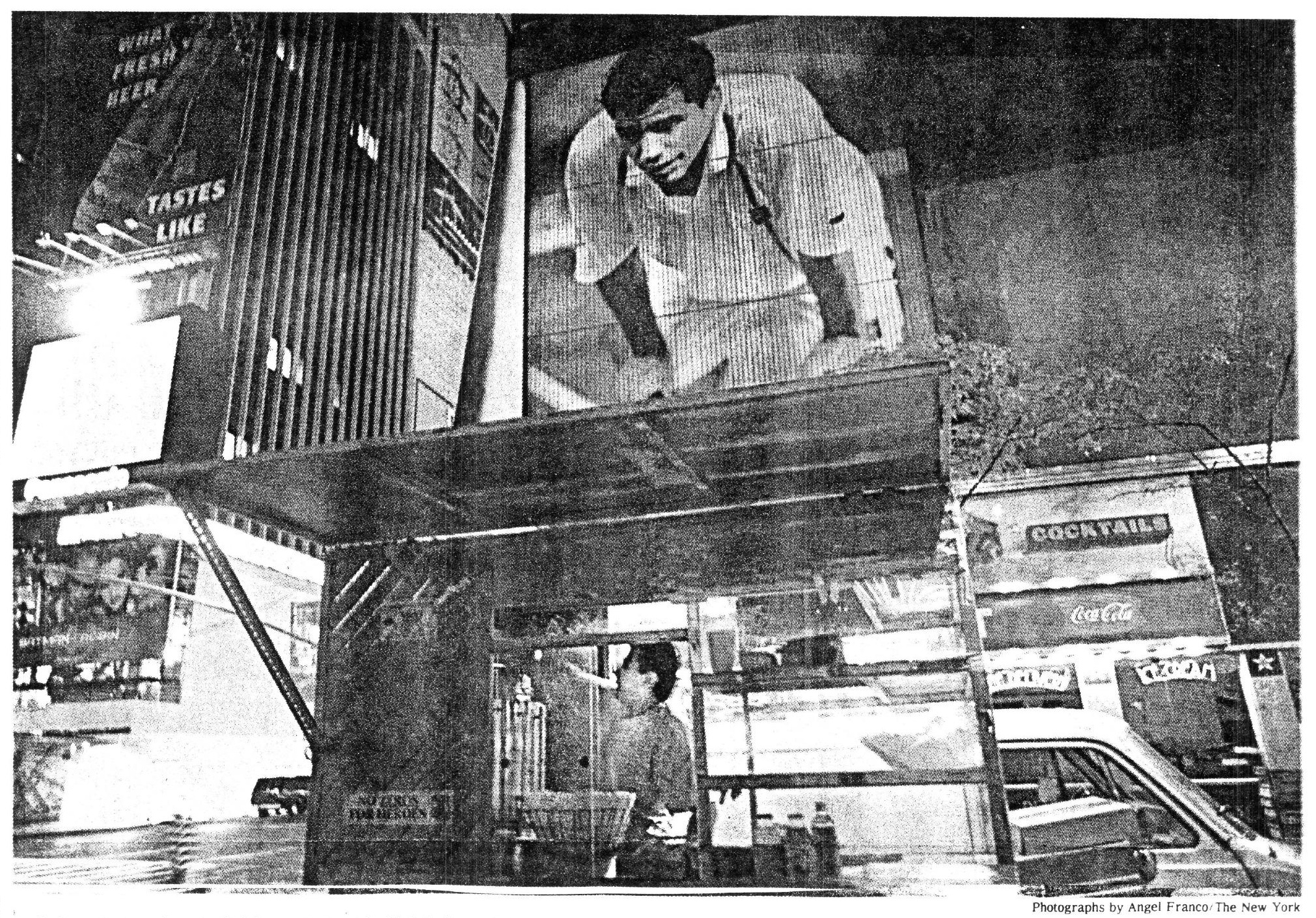

It is a little after 4 A.M., and Bashir Saleh is at his post on $43 \mathrm{~d}$ Street at Broadway. Two brothers also own coffee and bagel carts. 
But as Greek businessmen moved on, Afghan entrepreneurs moved in. Through word of mouth and connections made at prayer meetings at mosques from Paterson, N.J., to Flushing, Queens, Afghans eventually took control of the business.

"There are people who know what they are going to do in New York even before they leave Afghanistan," said Ali Saleh, 24, Mr. Saleh's younger brother and a vendor at 51st Street and Park Avenue. "People land here and the next week is like, 'Where do I get a license?' ",

Selling food has provided a living to wave after wave of immigrants who start with little money, limited English and only a vague understanding of American culture. Many Jewish, Italian, Korean and Greek immigrants have made livings selling food on the streets of New York; indeed some still do. And now Afghans have found a niche, catering to New York's fondness for coffee, mostly black, and a fat, round piece of bread with a hole in the middle. (Afghans rarely drink coffee, preferring green or black tea, and eat a long, flat bread.)

"I tell all my friends that it's an easy business to get into," Mr. Saleh, who estimates he has introduced about 70 friends to the business, said in fluent English. "All you have to know is "coffee doughnuts thank you have a nice day.' That's it. Something else: the coffee has to be good and you can't forget to smile."

That formula, however basic, has worked. Coffee vendors say they can make a profit of up to $\$ 700$ a week. For their thousands of customers, the appeal is obvious: in a city where a tiny cup of espresso can sell for $\$ 2.00$ at coffee bars, customers happily pluck down $\$ 1$ a day for coffee and buttered bagel.

For the pushcart operators, the advantages include no boss and little overhead cost. Armed with a license and a permit from the city's Health Department, coffee vendors can park their pushcarts anywhere in the city where vendors are allowed. With few exceptions, like parking in front of a fire hydrant or a bus stop, that means that vendors can also park near established coffee shops or even next to another pushcart.

The lack of restrictions is a mixed blessing. Vendors like their own freedom but worry that competitors may abuse it. With nothing but an unspoken code of ethics stipulating that a vendor may not steal another's spot, many vendors live in fear that somebody else, somebody who wakes up earlier than they do, will grab their place before they get there in the morning.

"We cannot punish a vendor for engaging in competition," said Fred Hooke, director of the vendor divi- sion of the city's Department or Bus1ness Services.

There are other disadvantages. The hot coffee machine makes summer unbearable. The front window remains open to winter's cold.

In his cart, Bashir Saleh moves around in about two square feet of space. Six shelves loaded with baked goods restrict his movements to the left. The coffee machine and a big cooler crowd him on the right. If he reaches up for supplies, his head brushes against the cart's top. There is no time or place to go to the bathroom. If he yawns, coughs, dozes off or blows his nose, his customers know it. By the end of the day, every day, he is exhausted.

Then, there are the hours, which some like and others, including $\mathrm{Ba}$ shir Saleh, most definitely do not. His day begins at 2:45 A.M. when he wakes up in Parsippany, N.J. In 15 minutes, he is out of the house and headed for the Manhattan garage on 30 th Street and 11th Avenue where he stores his cart. He buys about $\$ 100$ worth of coffee, juices and baked goods from a wholesaler and quickly loads his cart

At 4 A.M., he is on his post, where he stays until about noon. He takes the cart back to the garage, cleans it and heads home, where he sleeps three hours. When his four children return in the early evening, $\mathrm{Mr}$. Saleh wakes up to join the family and help with the homework. He goes to bed again at 10 or 11 P.M. After about four hours of sleep, he is up.

On busy streets, where vendors can sell more than $\$ 400$ a day, competition can be fierce, especially after the city moved to limit the number of streets available to vendors. Good spots are rarely available. People lay unofficial claim to their loca-



Jack Simkhayev, seated, is irked at Atamy Khairuddin's competing coffee cart, which is parked just across 53d Street at Madison Avenue.

tions and spend years Dunung up a clientele. They have no incentive to move unless a competitor offers them money: they may want anywhere from $\$ 5,000$ to $\$ 40,000$ to give up a good spot.

Very few vendors are willing to pay for a spot, though. Most vendors simply buy a cart, which can cost anywhere from $\$ 1,500$ to $\$ 10,000$, and roam the streets until they find a space they like. _.

At 53d Street and Madison Avenue, three pushcarts, not more than 12 feet from one another, are in fierce competition. One vendor even dropped his prices, selling three doughnuts for a dollar. Elsewhere, they sell for 50 or 75 cents each.

Their battle over the spot began about a month ago, when Atamy Khairuddin, an Afghan vendor, parked his new pushcart right across the street from where Jack Simkhayev, a Russian immigrant, has parked his own cart for about three years. Mr. Khairuddin's sudden appearance in the block has reduced Mr. Simkhayev's business by 40 percent, Mr. Simkhayev said.

To get back at Mr. Khairuddin, $\mathrm{Mr}$ Simkhayev's father, Alex, bought his own cart for $\$ 7,000$ and wedged it between Mr. Khairuddin's and another cart down the street that belongs to Steve Menexas, a Greek businessman. The elder Simkhayev, who dropped the price of the doughnuts, admits he is not making any money. His sole purpose is to drive Mr. Khairuddin away from his son's territory, he said.

So far, none of the men has been willing to back out of the competition and search for another spot.

$\mathrm{Mr}$. Khairuddin is taking no chances. He says he does not sleep at nights anymore, fearing that someone will take his place. At 1 A.M. every day, Mr. Khairuddin parks his locked inside, he awaits dawn.

$$
\text { . }
$$




\section{Afghanistan is an archaeologist's paradise. But its carefully nurtured collection of antiques is vanishing, plundered by looters and sold to the West. Report by \\ Roland-Pierre Paringaux and Emmanuel de Roux}

$\mathbf{T}$ HE archaeologist Nancy Dupree, who is based in Peshawar, the Pakistani city near the Afghan border that thrives on all kinds of trafficking, knows all too well that one of this century's great cultural disasters, the plundering of Kabul museum and its riches, continues apace. Yet she is helpless to do anything about it.

"A dealer came to see me yesterday for the second time in a year," she says. "He offered me a terracotta I knew well because I'd already held it in my hands. It broke my heart, but I had to give it back to him. The first time he had wanted $\$ 120,000$ for it, and now he wanted $\$ 30,000$. But how could I come up with the money? There probably won't be a third time."

Many people have simply given up. But Dupree, a tall American whose expression has lost none of its girlishness over the years, is still fighting for a culture to which she and her late husband devoted their lives - until the war destroyed everything.

Nancy Hatch Dupree's time in Afghanistan began with a double love affair. The country itself, a kingdom perched between the Himalayas and the steppes of Central Asia, immediately appealed to her when she arrived there in 1962 as a diplomat's wife.

Then she fell in love with Louis Dupree, an eminent American archaeologist whose work had eventually taken him to Afghanistan, a country that had long been the preserve of French archaeologists.

Nancy wrote a guidebook for the Afghan Tourist Office and gave her manuscript to Dupree to read. As she stood before the desk of the great man, she felt "as intimidated as a schoolgirl in front of her teacher", even thoung she was a graduate of Columbia university.

He handed back her manuscript without a word, after writing on it: "Correct but unoriginal." She turned on her heels and stomped out of the room, slamming the door. He ran after her, mumbled a few excuses and asked her to stay to lunch. They remained inseparable after that. She accompanied him on all his expeditions to Kandahar, Jalalabad and Mazar-e-Sharif.

Archaeologists dream of working in Afghanistan, a country which en- joys a unique location between Iran, India and China. For thousands of years, different civilisations were thrown into contact with each other there by the great invasions of Alexander the Great, Genghis Khan and Tamerlane, by major religions (Hinduism, Buddhism and Islam), and by caravans travelling along the Silk Road that linked the Mediterranean basin with China.

Century after century, fresh cultural strata and new treasures accumulated in Afghanistan's high mountain valleys. This process of cultural cross-fertilisation produced the Greco-Buddhist style that is characteristic of Gandhara statues, the treasures of Bagram, where Greco-Roman glassware rubs shoulders with Indian ivories, Persian gold objects and Chinese lacquer work, and the Islamic art of the kingdom of Herat, which is celebrated for its miniatures.

Those prodigious treasures began to emerge from the ground in the 1920 s, thanks to the determination of the forward-looking King Amanullah, who gave the French archaeological delegation in Afghanistan exclusive excavation rights for a 30 -year period.

During the inter-war years, the French excavated Bagram plain, north of Kabul, the prehistoric sites of $\mathrm{Ai}$ Khanum and Balk on the northern frontier, and the Buddhist valleys of Bamian, west of Kabul, and Hadda, near Jalalabad. Soon between France and Afghanistan began to fill Kabul museum, a brick building in the south of the city near the royal palace.

From 1949 on, the French were joined by other archaeological missions, and in particular by Louis Dupree's American team. There was an abundance of sites in Afghanistan. The sixties and seventies were halcyon years. Dupree, who specialised in prehistory, travelled the length and breadth of the country in his old red Land Rover, always accompanied by Nancy.

Unfortunately, storm clouds were gathering. Caught as it was, at the height of the cold war, between two powerful neighbours, the Soviet Union to the north and the United States' ally, Pakistan, to the east, Afghanistan had the greatest difficulty treasures that were to be divided up

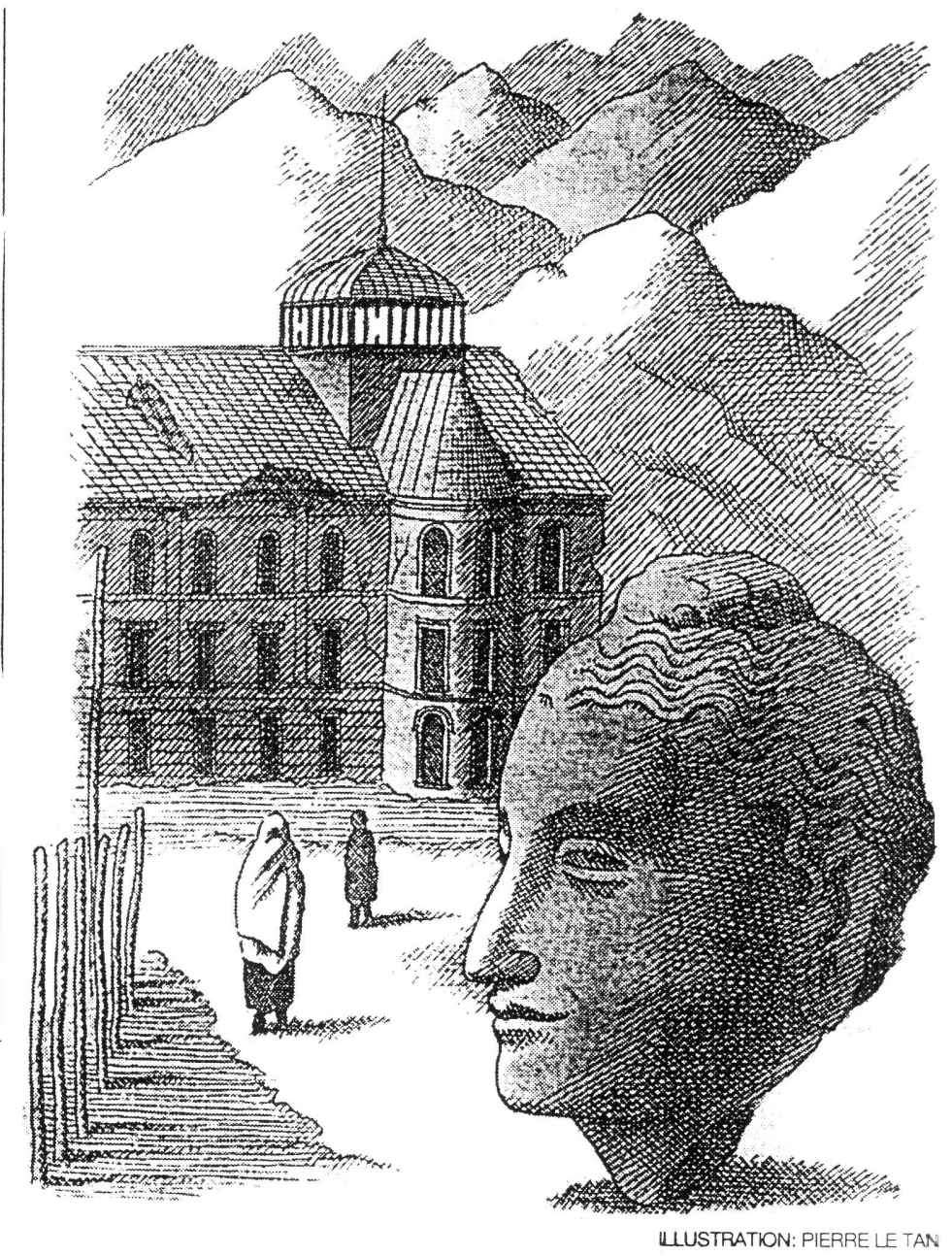

in maintainıng its independence.

In April 1978, a communist regime came to power following a military coup. Louis Dupree was accused of being a CIA agent and briefly arrested. "In the eyes of the new regime there could be no other explanation for the length of his stay in Afghanistan," Nancy remembers with a shrug of the shoulders.

The Duprees went into exile in Pakistan, where they watched helplessly as the Soviet Union invaded Afghanistan and the country was sucked into a spiral of destruction that has continued ever since.

In 1992, after the defeat of the Red Army and the mojahedin's triumphant march into Kabul, the Duprees, like millions of other refugees, thought they would soon be able to return "home". Their moment of euphoria was shortlived. Very soon the warlords and ayatollahs that were sharing power began fighting among themselves and the situation degenerated into a fullblown civil war.

During the winter of 1994-95, the battle of Kabul reduced the south of the capital to rubble. In all those 36 years of attack and counterattack, Kabul museum was repeatedly hit by rockets, set on fire and looted. "Not all the looters were illiterate mojahedin," Nancy says. "Some of them took their time to choose the finest items or those most in demand on the international market."

In September 1996, as the rundamentalist Taliban army tightened its stranglehold on Kabul, a handful of foreign volunteers drew up a list of items left in the devastated museum and took them to a hotel in Kabul's centre. The 275 crates packed into a few hotel rooms were all that remained of a museum whose great diversity owed a lot to half a century of international co-operation.

This last-minute operation rescued less than 20 per cent of the total collection and included many damaged items and pieces of minor importance. The museum's major treasures were almost all missing. Gone were the 1,700 pieces from Bagram, including several hundred second century carved ivory reliefs discovered by the French in 1939. Hundreds of Greco-Buddhist 
bronzes, ceramics and statues had disappeared. There was no trace of the museum's 35,000 gold and silver coins from Tepe Maranjan, Kunduz and Mir Zakah.

Nor was there any sign of the 20,000 "barbarian" gold objects and pieces of jewellery that made up the glorious Scythian Tilia Tepe treasure, which was excavated by an Afghan-Soviet team in 1978. They are thought to have been taken to the safety of a vault in the national bank. But despite repeated requests bank officials have refused to show them.

A LARGE proportion of the museum's prize items have found their way discreetly into Pakistan. In a region where arms and opium trafficking is rife, they are easily smuggled across the border. After crossing "tribal territories" where there is no form of control, the pieces generally end up in Peshawar.

It is not unusual, in that city's bazaars and markets, to find items from the museum alongside crude forgeries. But the really choice pieces are to be found elsewhere, and you are not shown them unless you have the proper credentials.

One person who has them is John $\mathrm{W}$, an antique dealer from London's Old Bond Street, who says he went to Peshawar "to help. rescue the treasures of Kabul museum, and not out of any commercial motives". After being contacted at his hotel by a man who had been sent by a local politician, "a certain Mr. Amin, who claimed to have been a minister", John W was taken after nightfall to a villa guarded by armed men.

After tea had been served and a few pleasantries exchanged, a man took "several dozen" Bagram ivories wrapped in pink toilet paper out of a suitcase. Some of them had been damaged. John $\mathrm{W}$ was flabbergasted, as there are known to be only a few hundred such ivories, and because Amin offered him the lot for $\$ 10$ million.

He learnt shortly afterwards that General Nasirullah Khan Babar, - who was Benazir Bhutto's interior minister at the time, possessed a collection of the priceless ivories.

This would seem to be confirmed by the experience of $\mathrm{Dr} \mathrm{H}$, a Pakistani art expert who lives in Islamabad: "One morning I was visited by General Babar. He showed me seven ivories that a dealer was offering him for $\$ 300,000$. They were items from Kabul museum and I told him so. I have since heard that the pieces probably found their way to London or Tokyo."

When the general came on an official visit to Paris in 1996, he is alleged to have said, as he pored over the collection of Bagram ivories at the Musée Guimet: ${ }^{\text {Not }}$ bad, but the ones I've got at home are better!".

Benazir Bhutto, whose love of antiques is well known, is also undersuspicion. A Pakistani academic says he accompanied her to Peshawar in 1996 to authenticate archaeological items from Afghanistan.

There was talk at the time of setting up an official fund to acquire the stolen antiques, so they could be returned to Afghanistan once peace was restored. Shortly afterwards, the Pakistani press reported ru mours of an inquiry by the secret service into antique trafficking by people in Bhutto's cabinet.

The same academic says that, when he was invited to the villa of a prominent Muslim leader in Baluchistan province last year, he found himself face to face with several hundred antiques from the Afghan province of Herat. When he

expressed surprise, his host told him he possessed "as many again in a Karachi warehouse which are on their way out of the country".

In 1996, the Islamabad-based Professor Hassan Dani was asked to examine 12 large Gandhara statues that had turned up in the Pakistani border region of Malakand. By the time he got there they had already gone abroad. John W confirmed last month that the pieces had in fact been seen on the market in London.

Professor Dani talks of "a veritable haemorrhage of the Afghan heritage". This is a view echoed by Nancy Dupree: "Everything is very well organised. The major pieces are buried in Afghanistan. Photographs of them are circulated among art dealers, collectors and diplomats. As soon as there's a buyer, they turn up in Peshawar. As they go from place to place everyone gets their cut." The pieces are then sent to unscrupulous dealers all over the world.

Not just Kabul and its museum have suffered: the whole of Afghanistan has been ransacked. In her Peshawar office, Dupree points to aerial photographs that show unauthorised excavations being carried out on several archaeological sites.

Some patches of land are pockmarked with craters which, for once, are not the result of bombing. "They are concessions sold by certain mojahedin leaders - it's like the Californian gold rush," she says.

$\mathbf{P}$ REHISTORIC sites such as Ai Khanum, Telia Tepe and Surkh Kota, which could pro vide clues that would make it possible to piece together Afghanistan's mutilated past, have been plundered in this way and, otten, Irreparably lost.

Despite this disastrous state of affairs, Dupree has refused to give up. She runs Acbar, a documentation centre whose purpose is to act as a memory bank for these troubled times, and supports Spach, an association for the protection of Afghanistan's cultural heritage. She travels all over the world to muster backing for such causes.

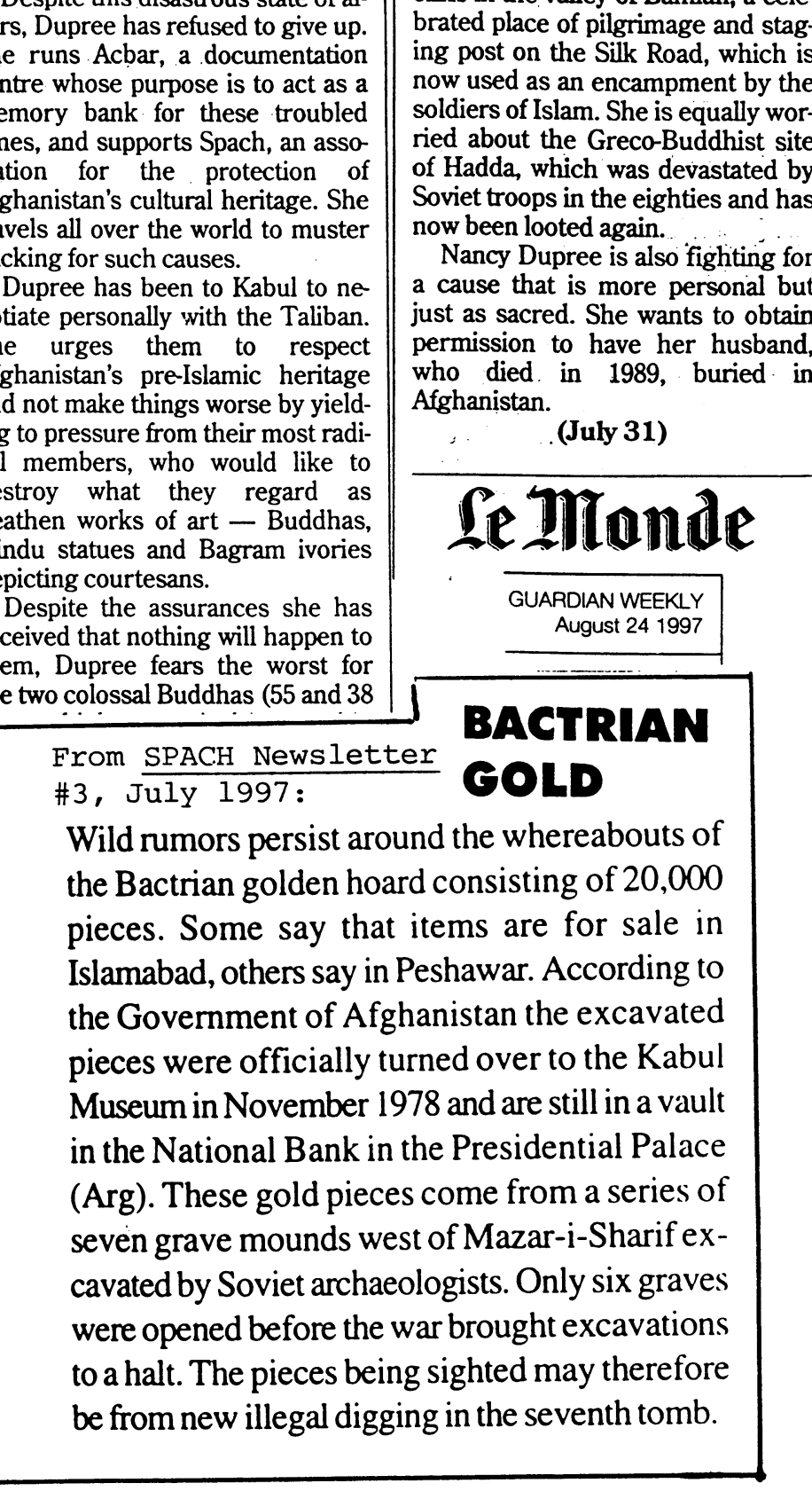
gotiate personally with the Taliban.

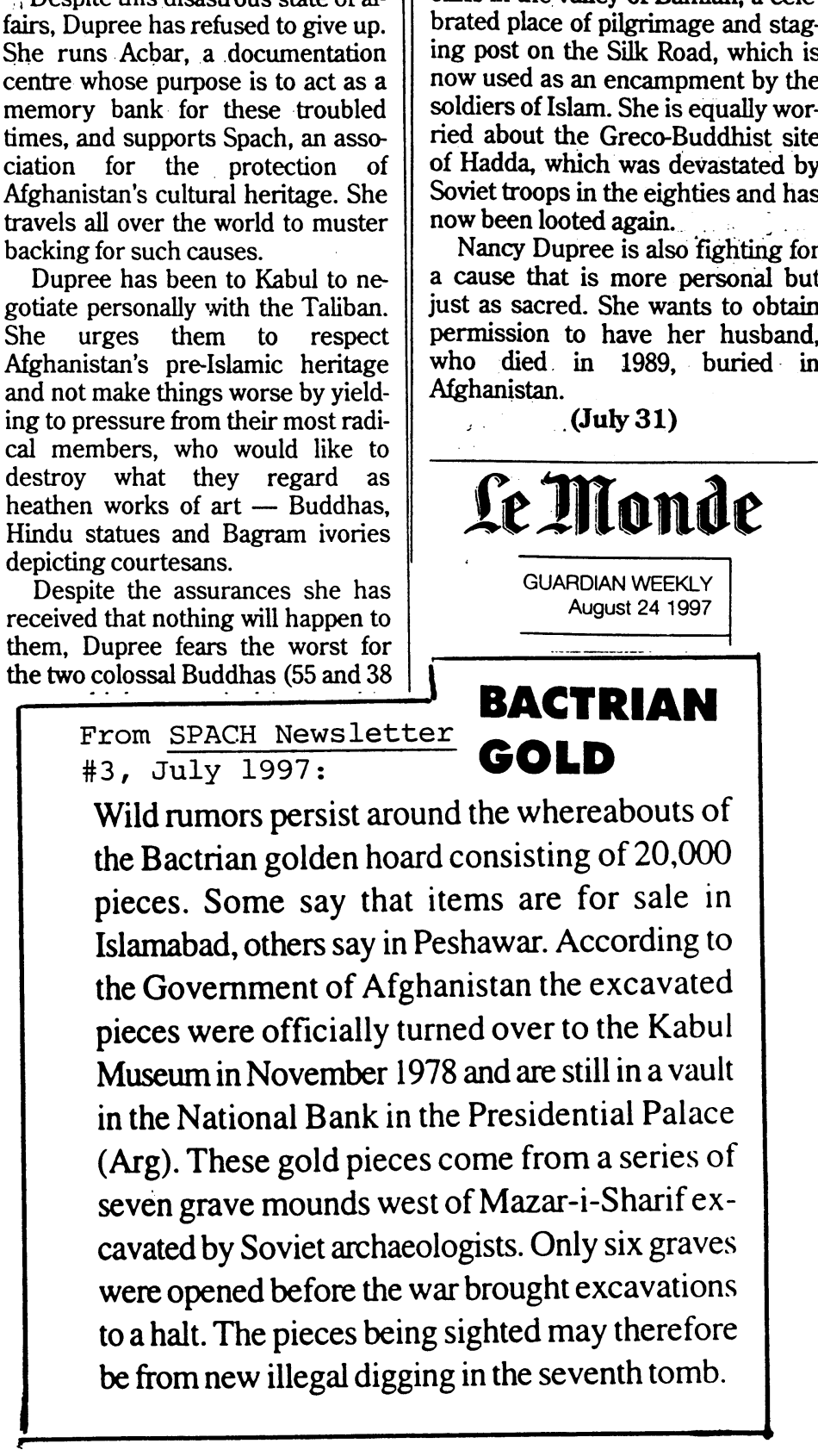

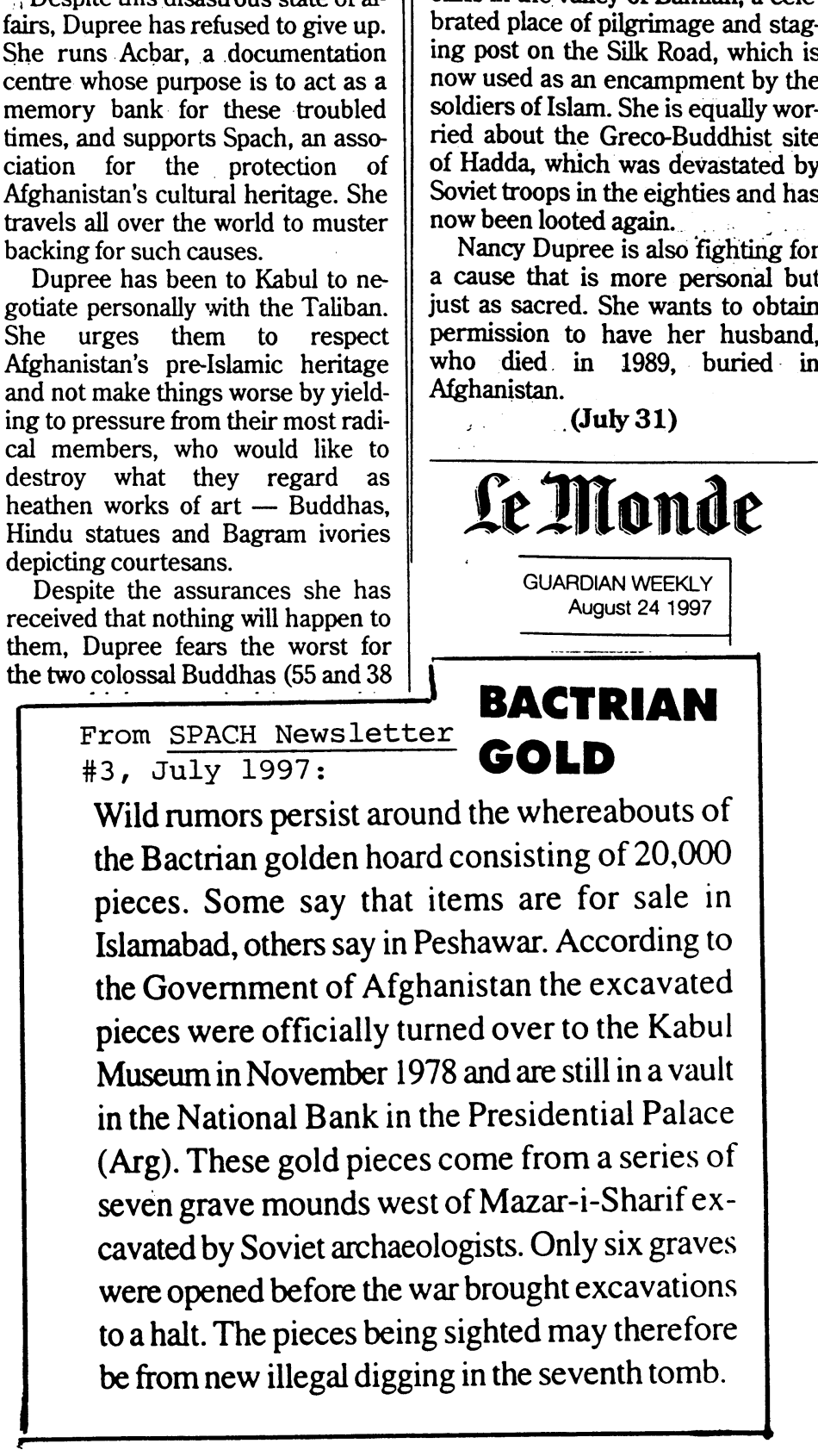

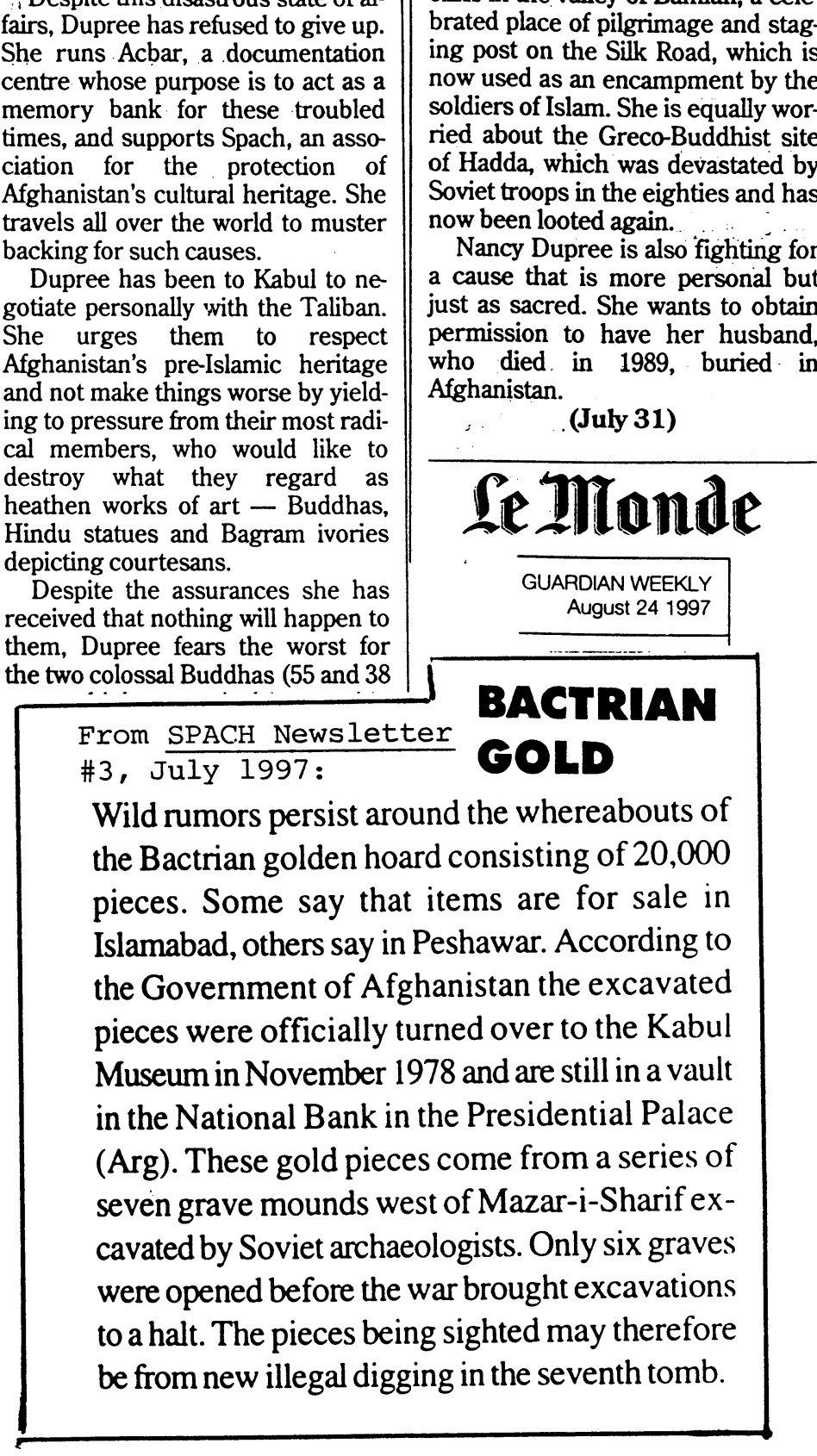

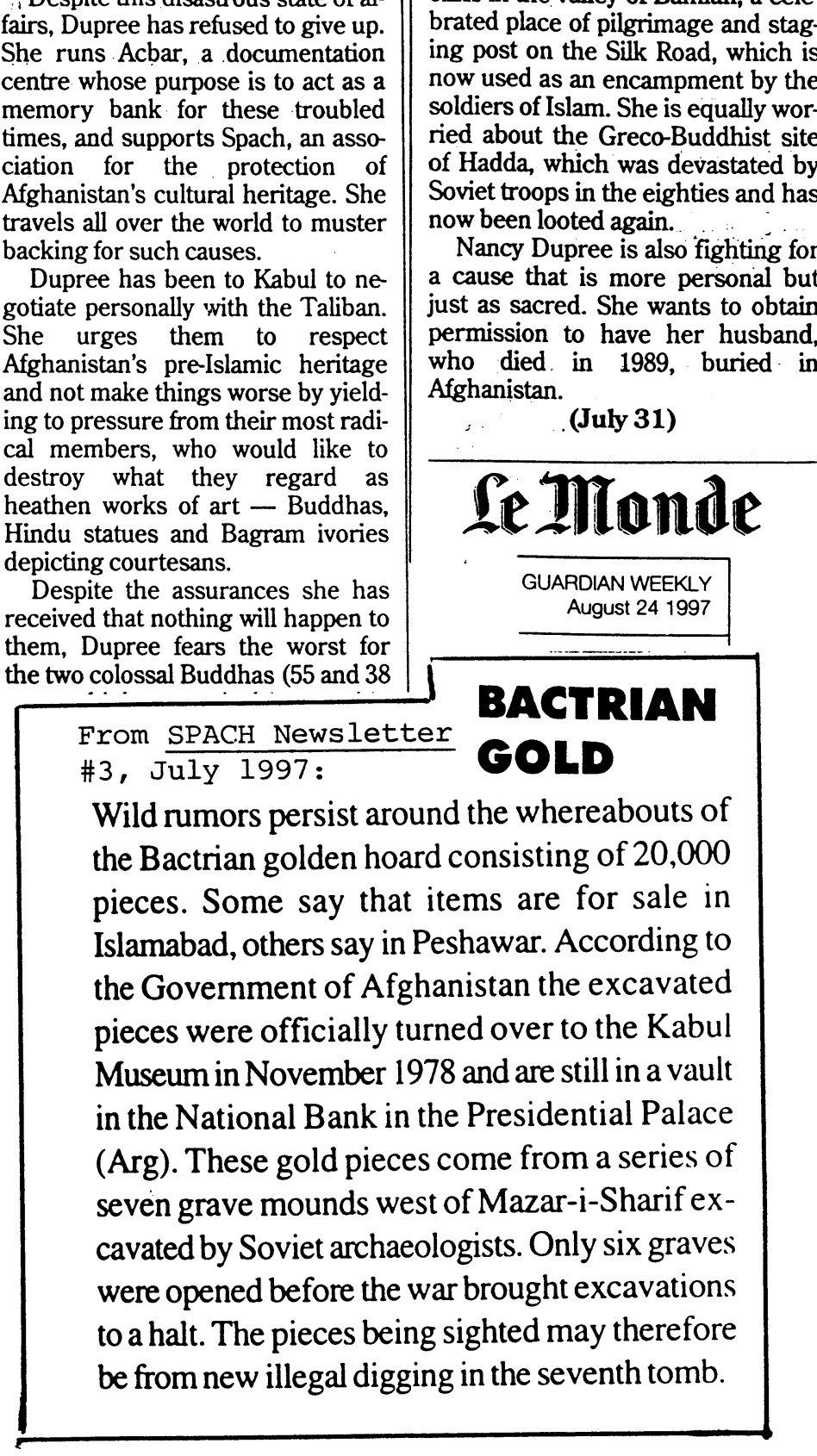

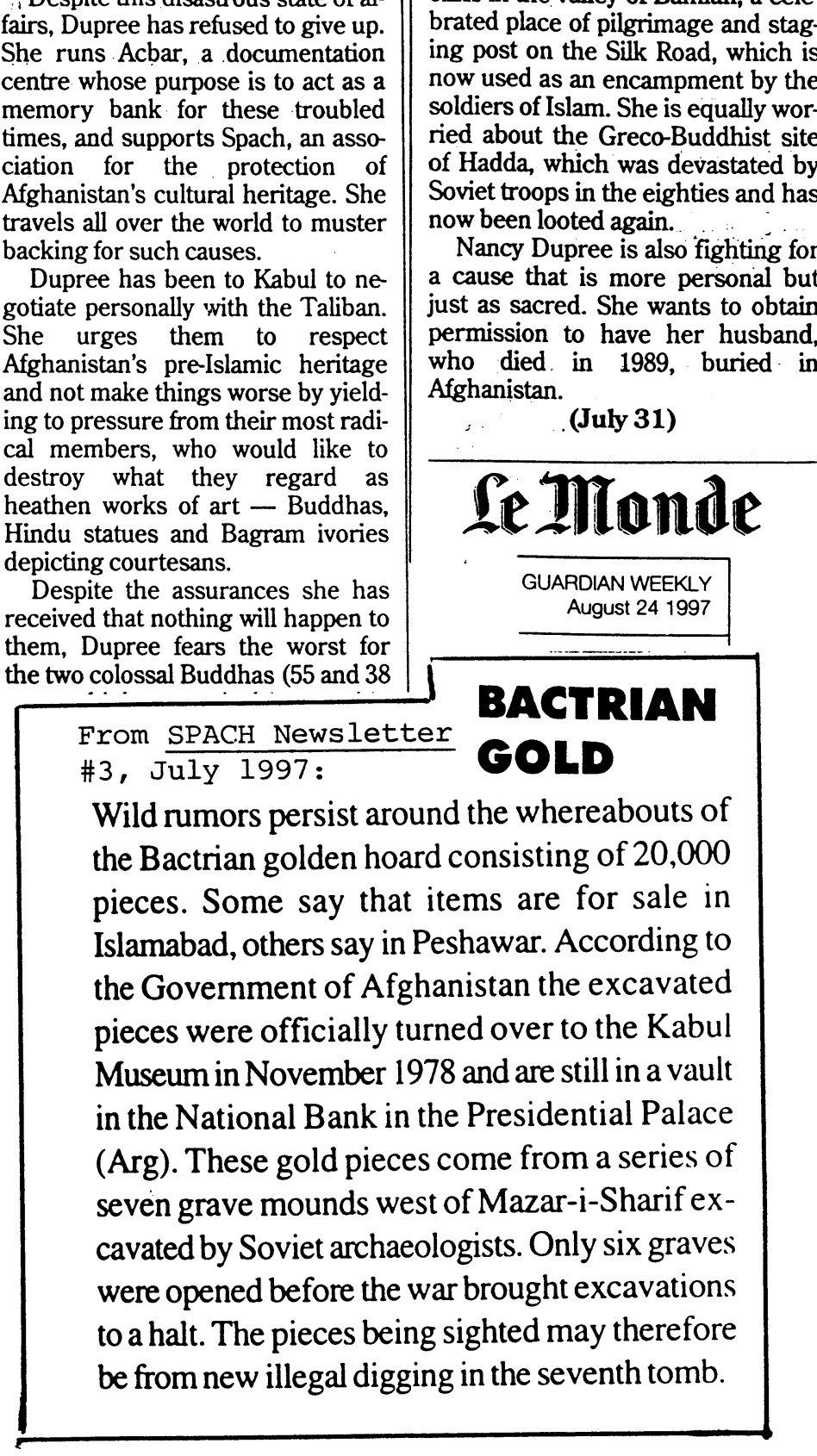

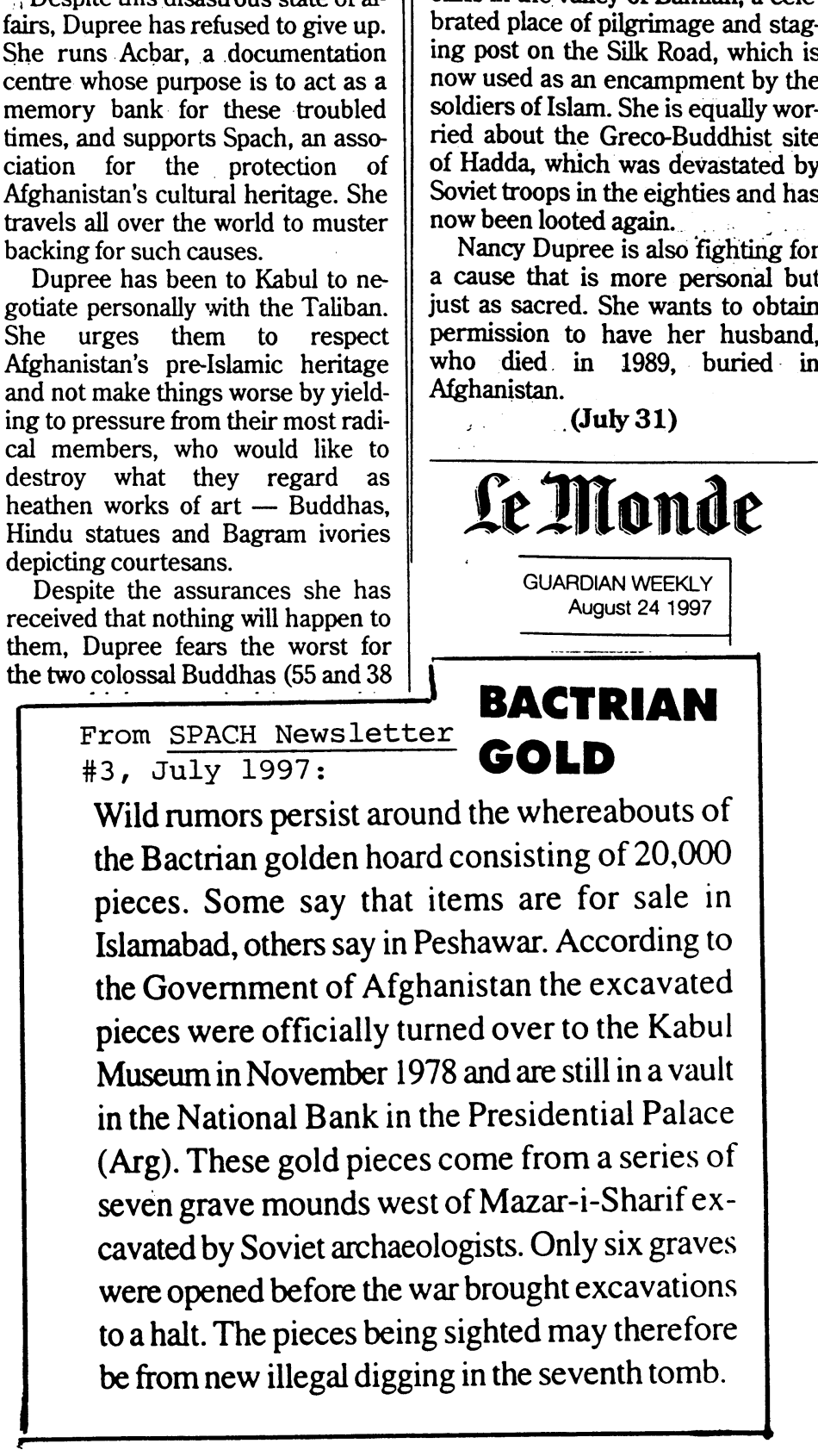

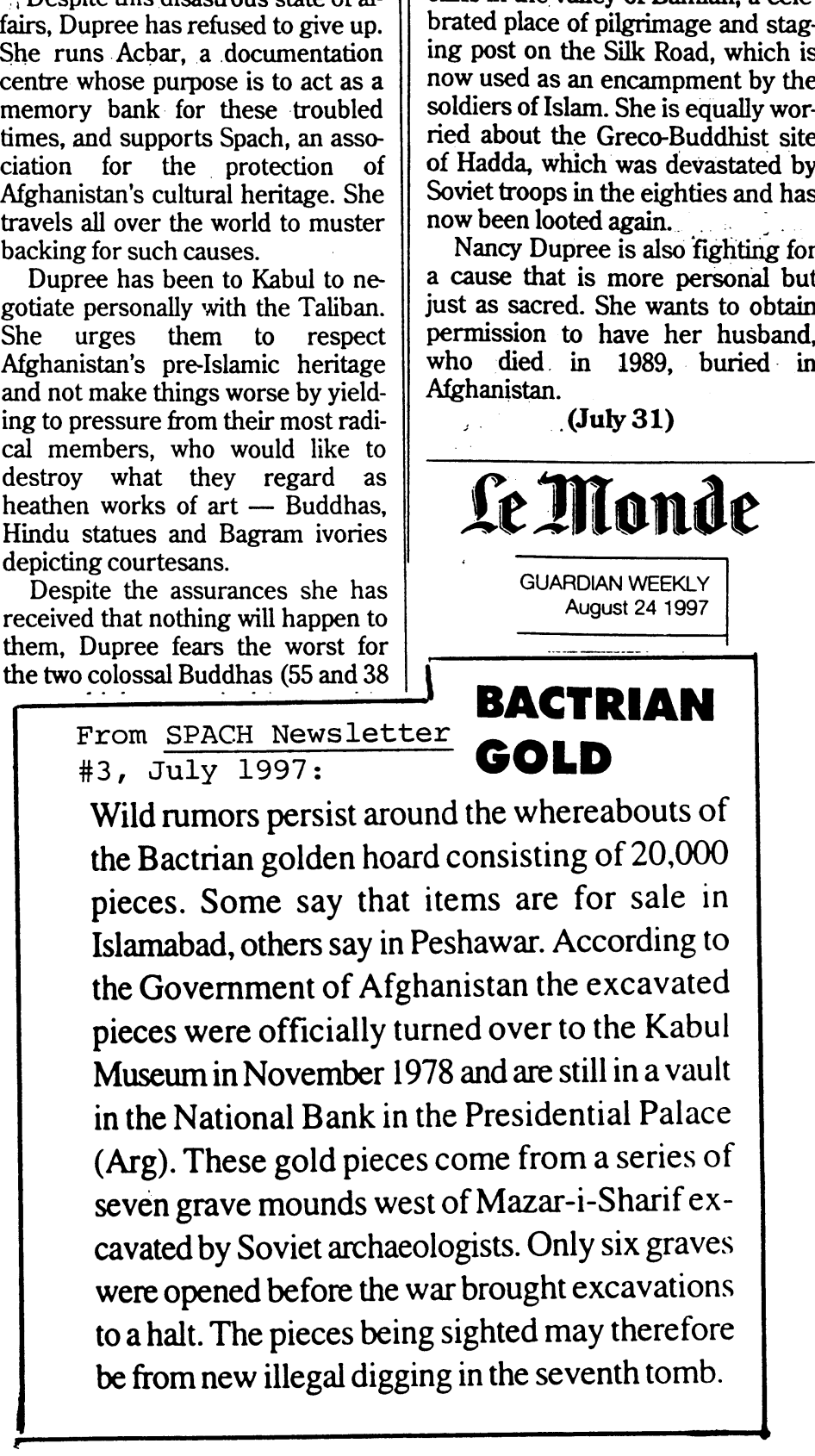

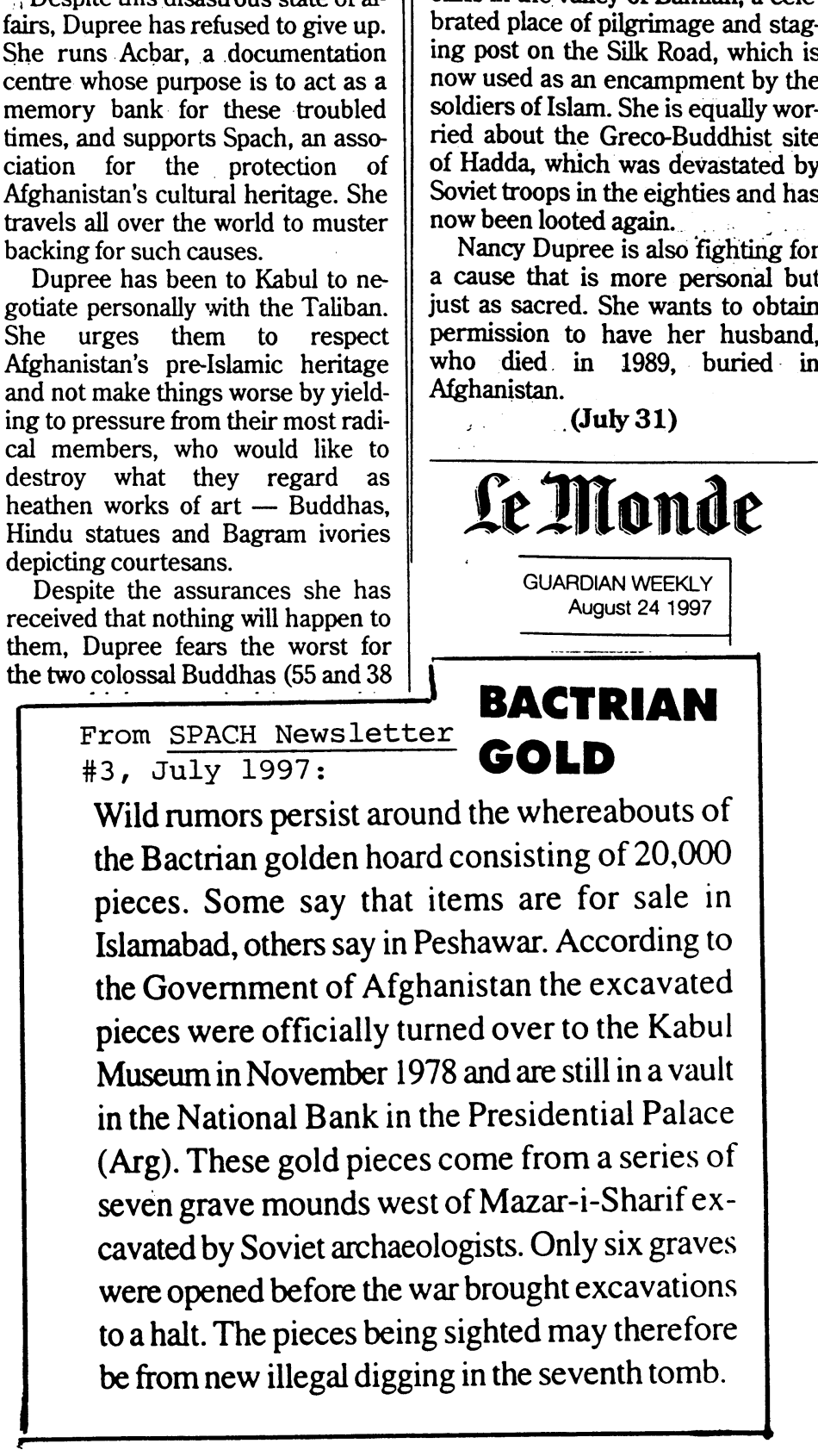
depicting courtesans.

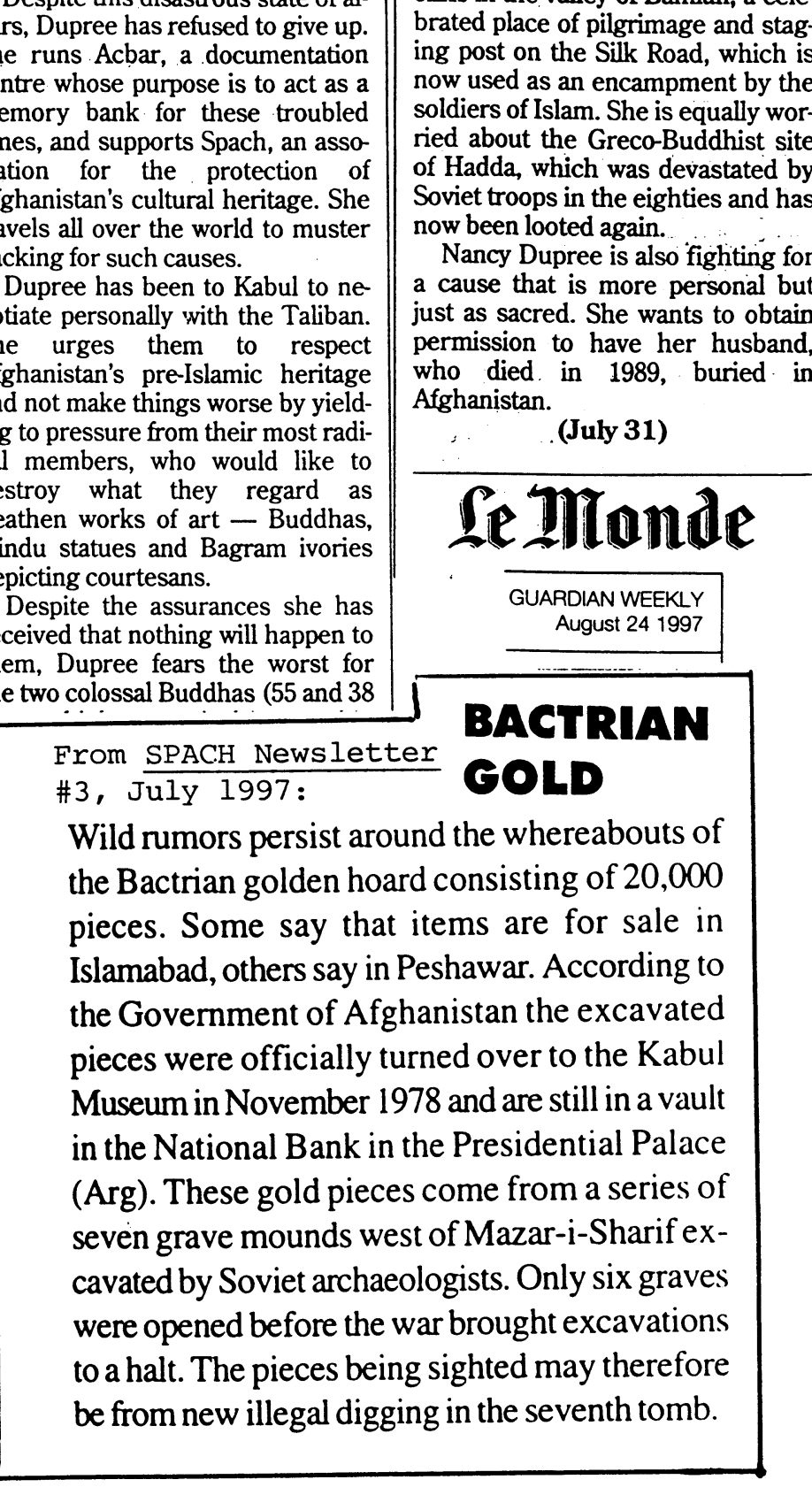

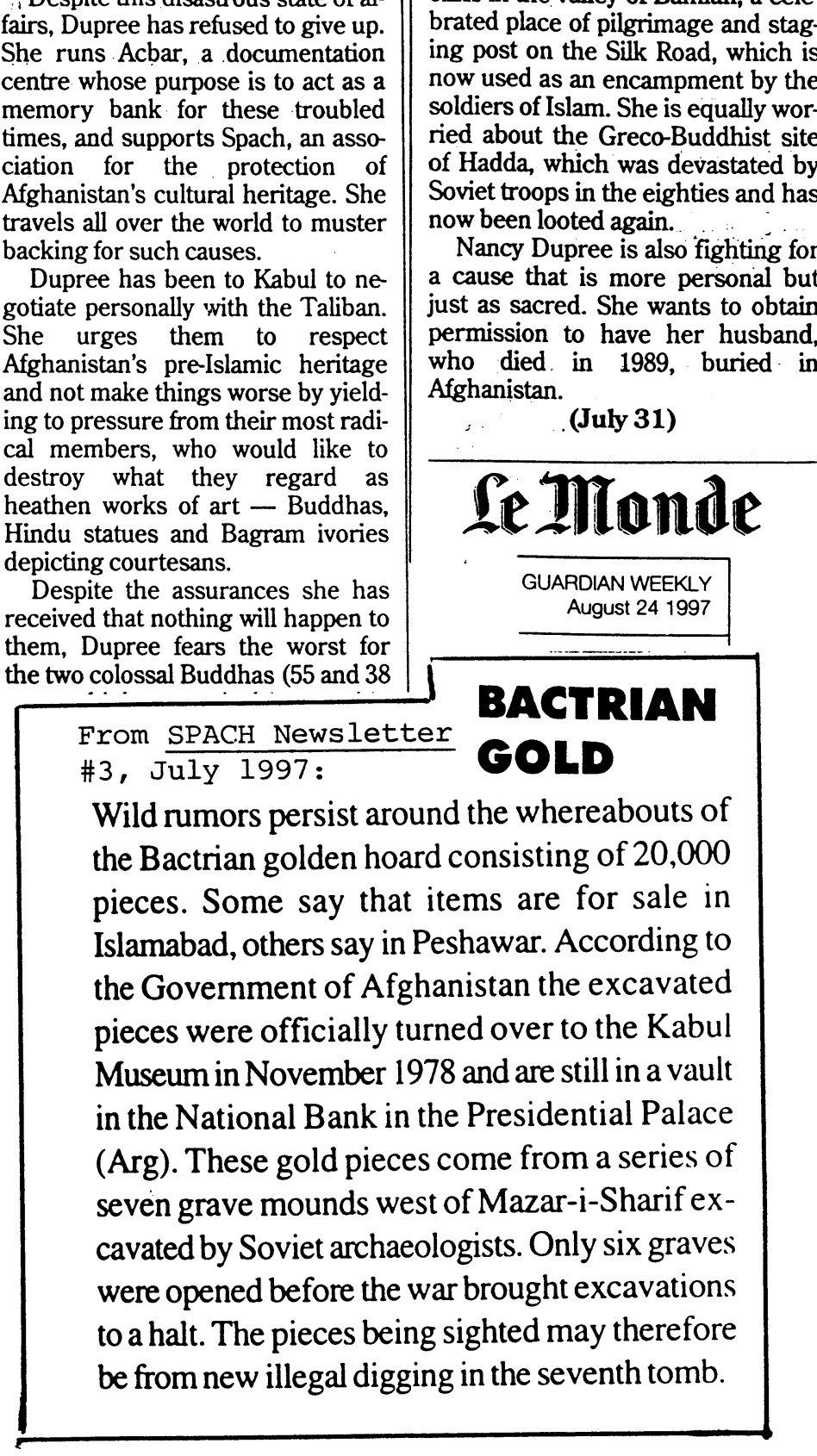

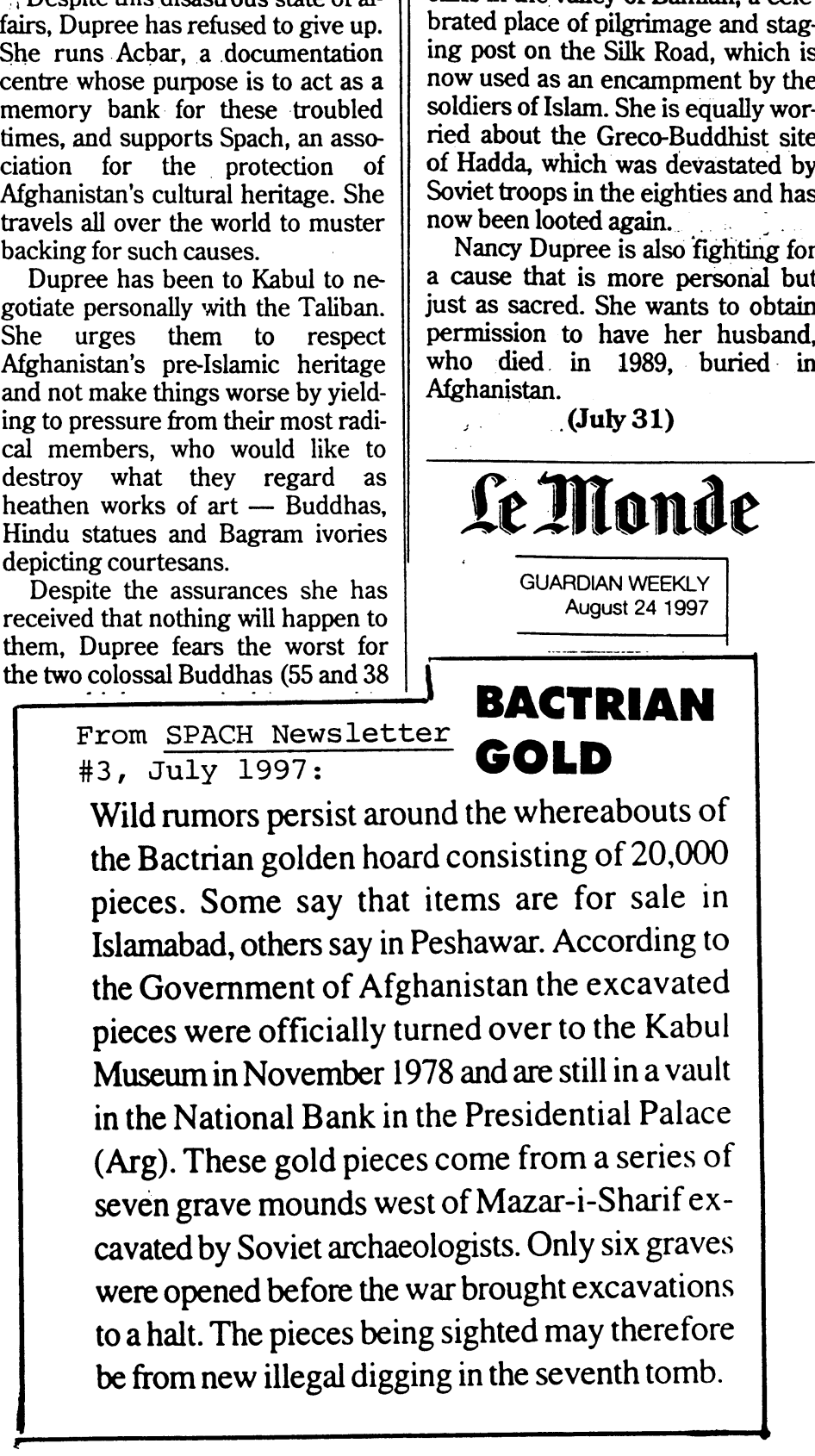

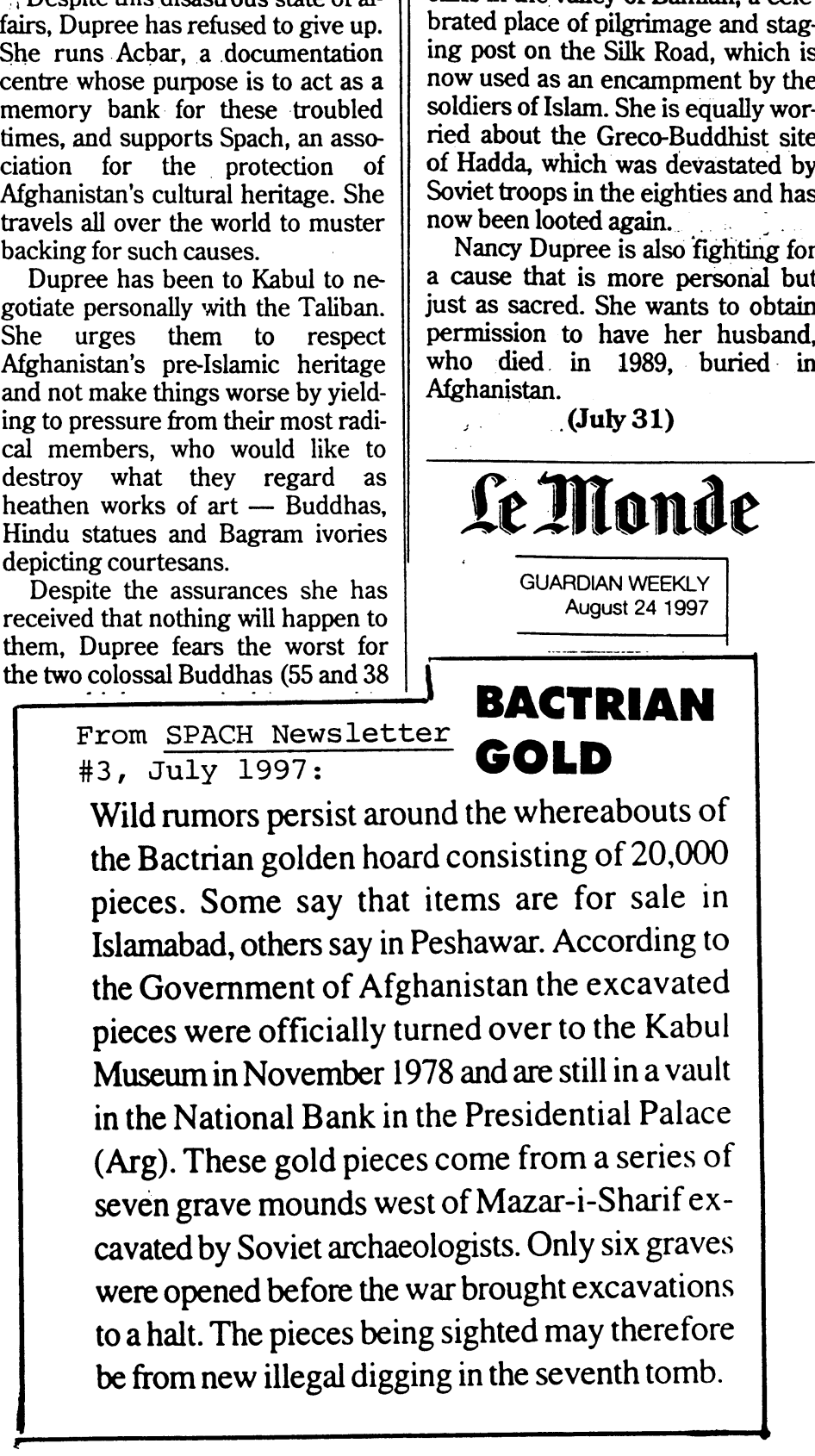

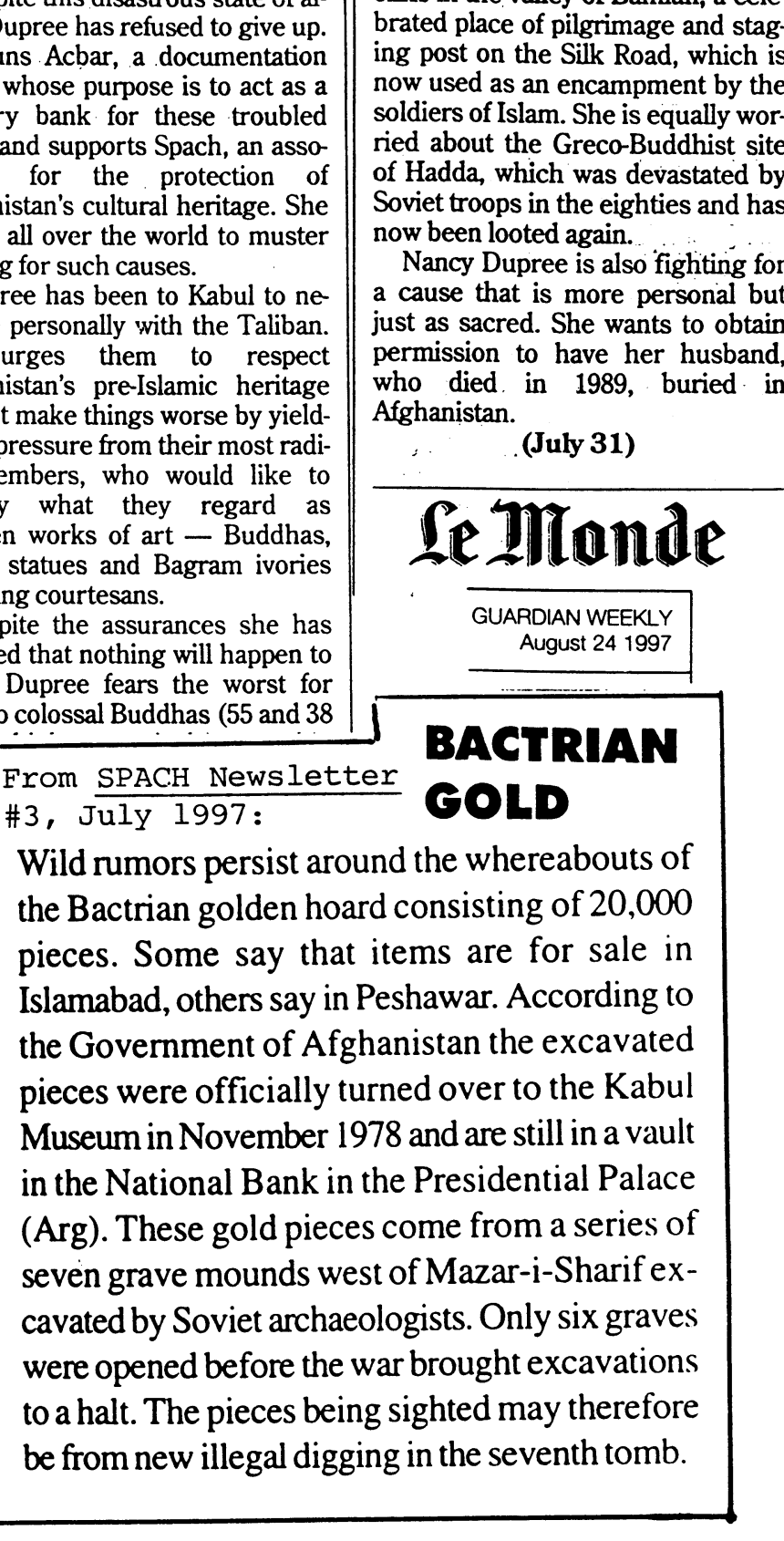

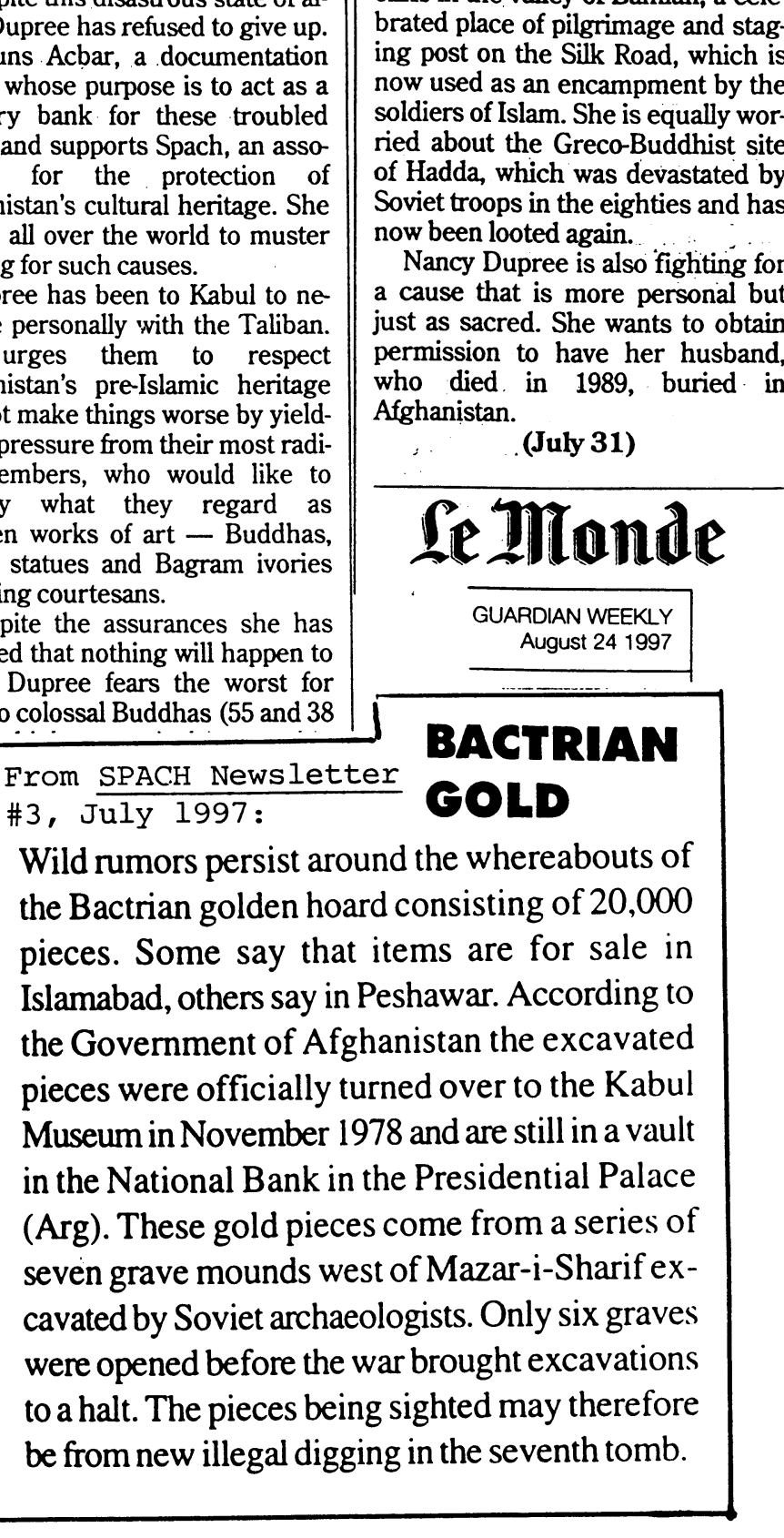

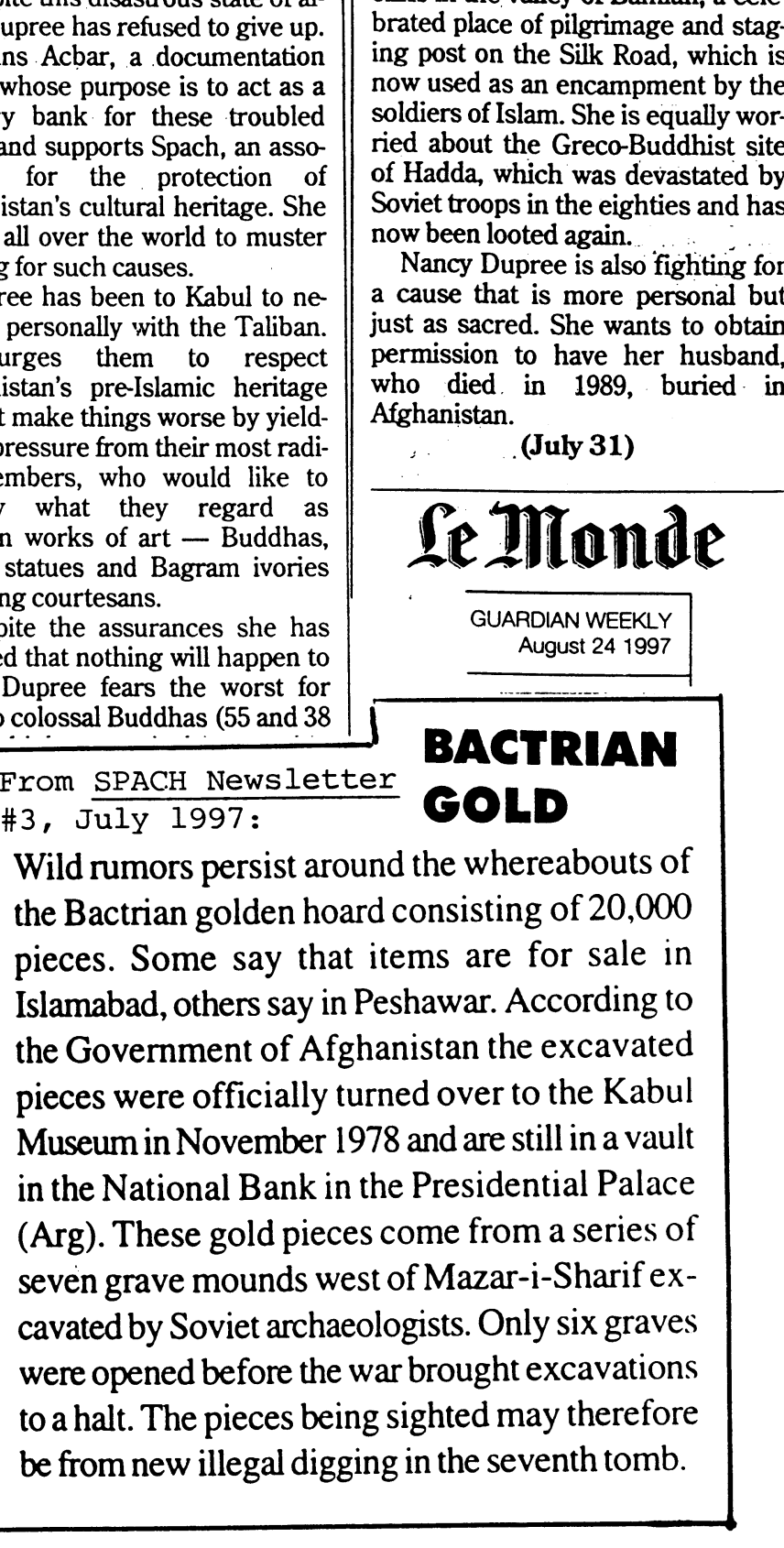

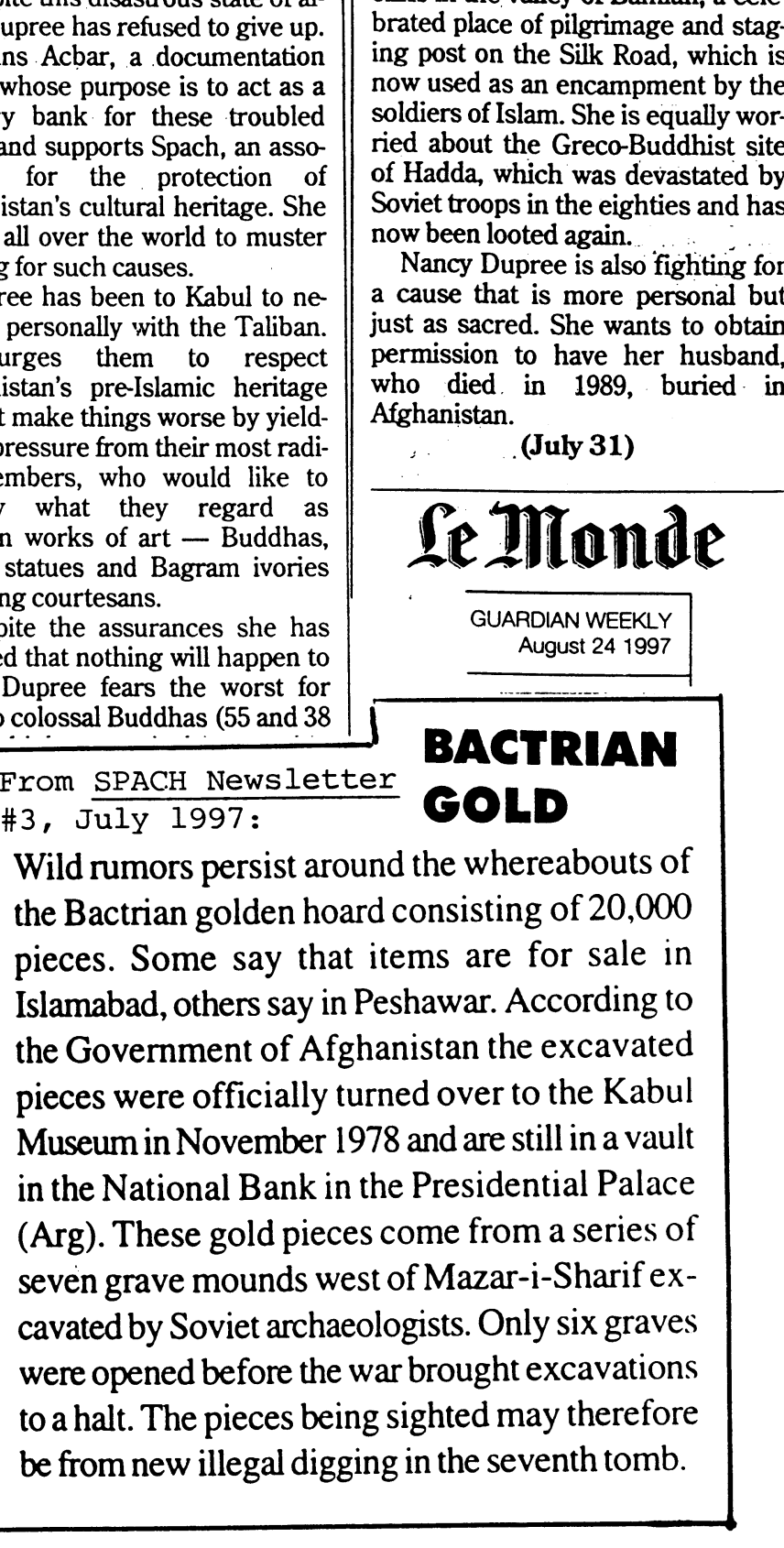

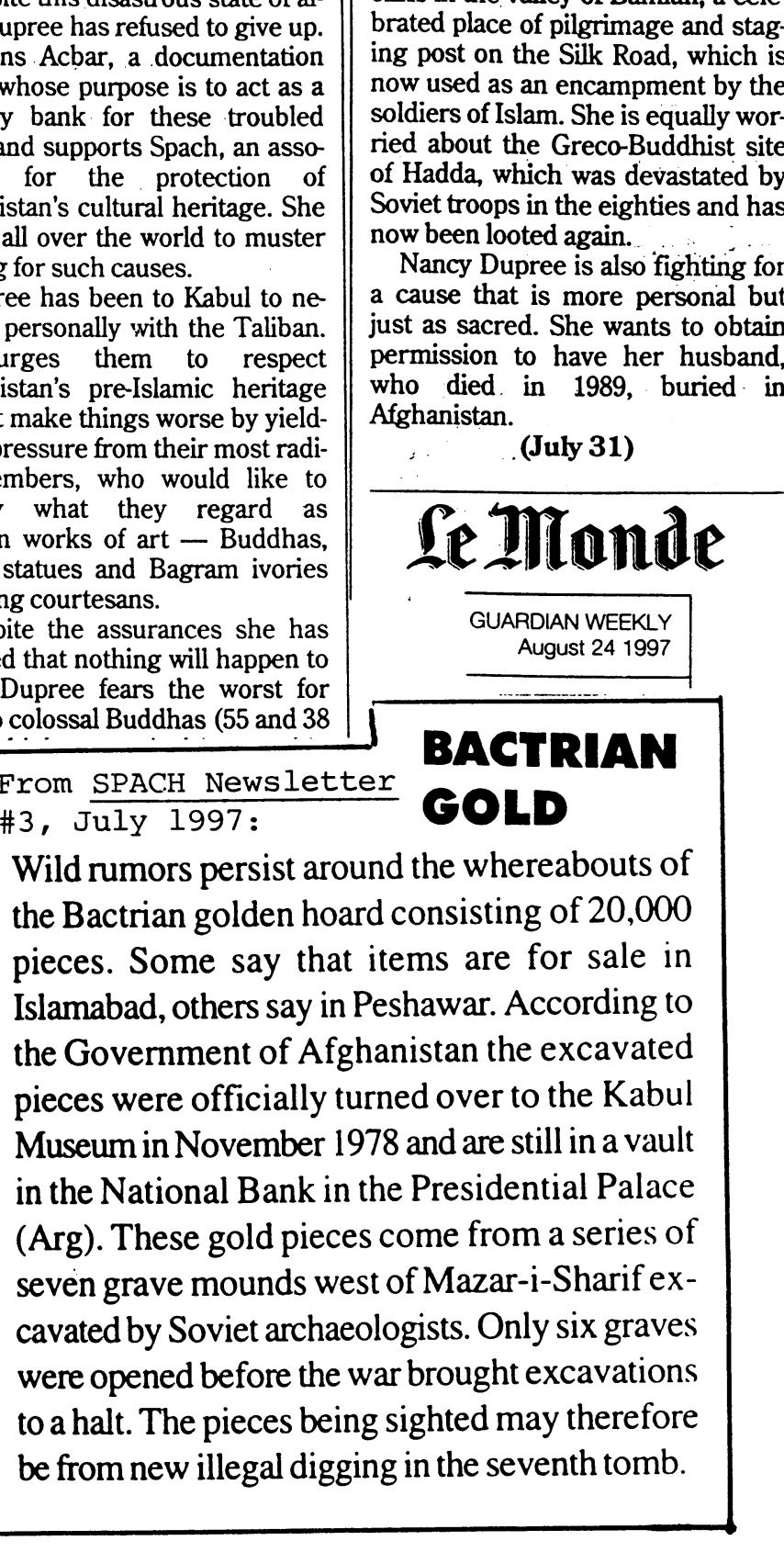

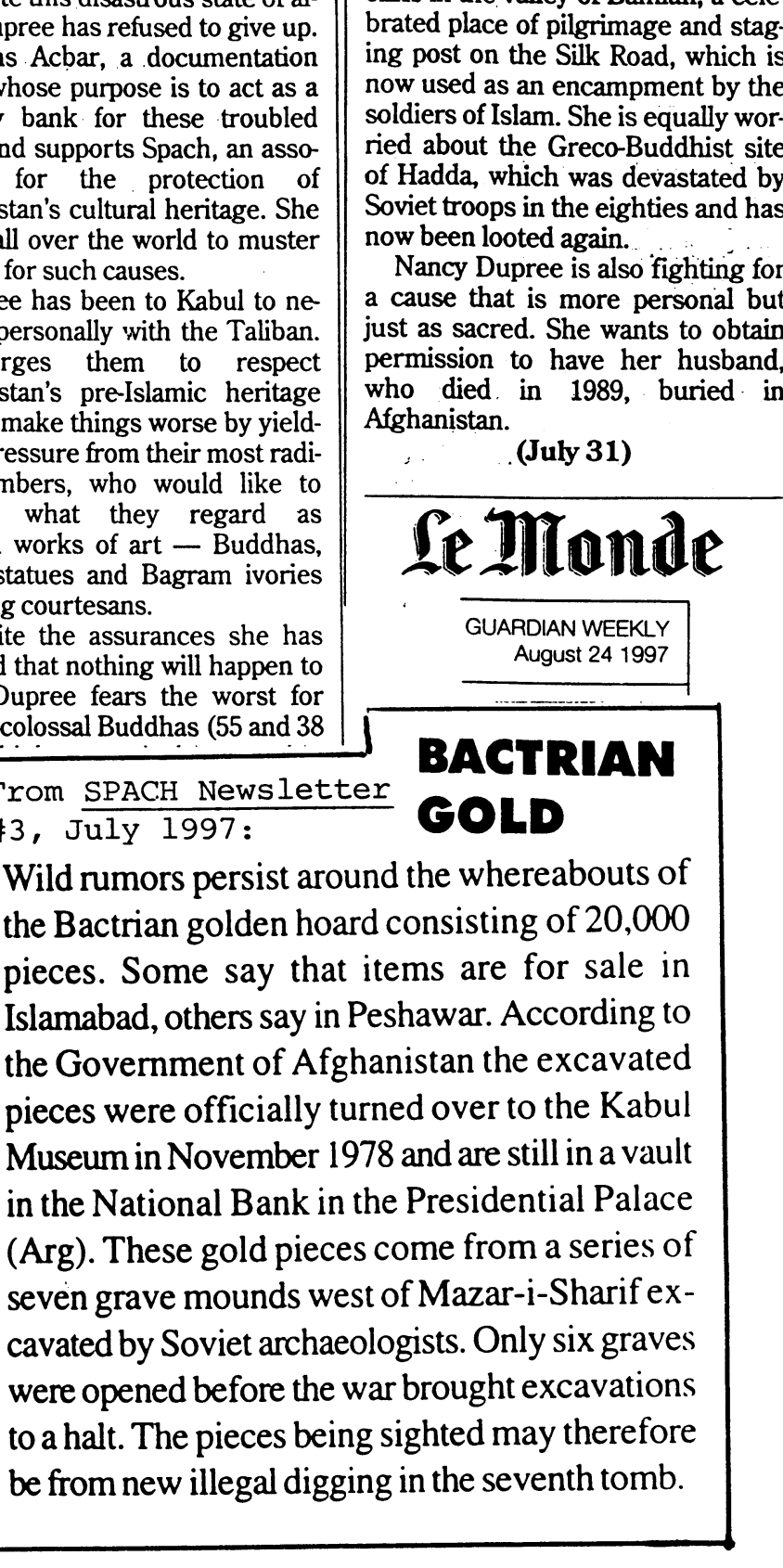

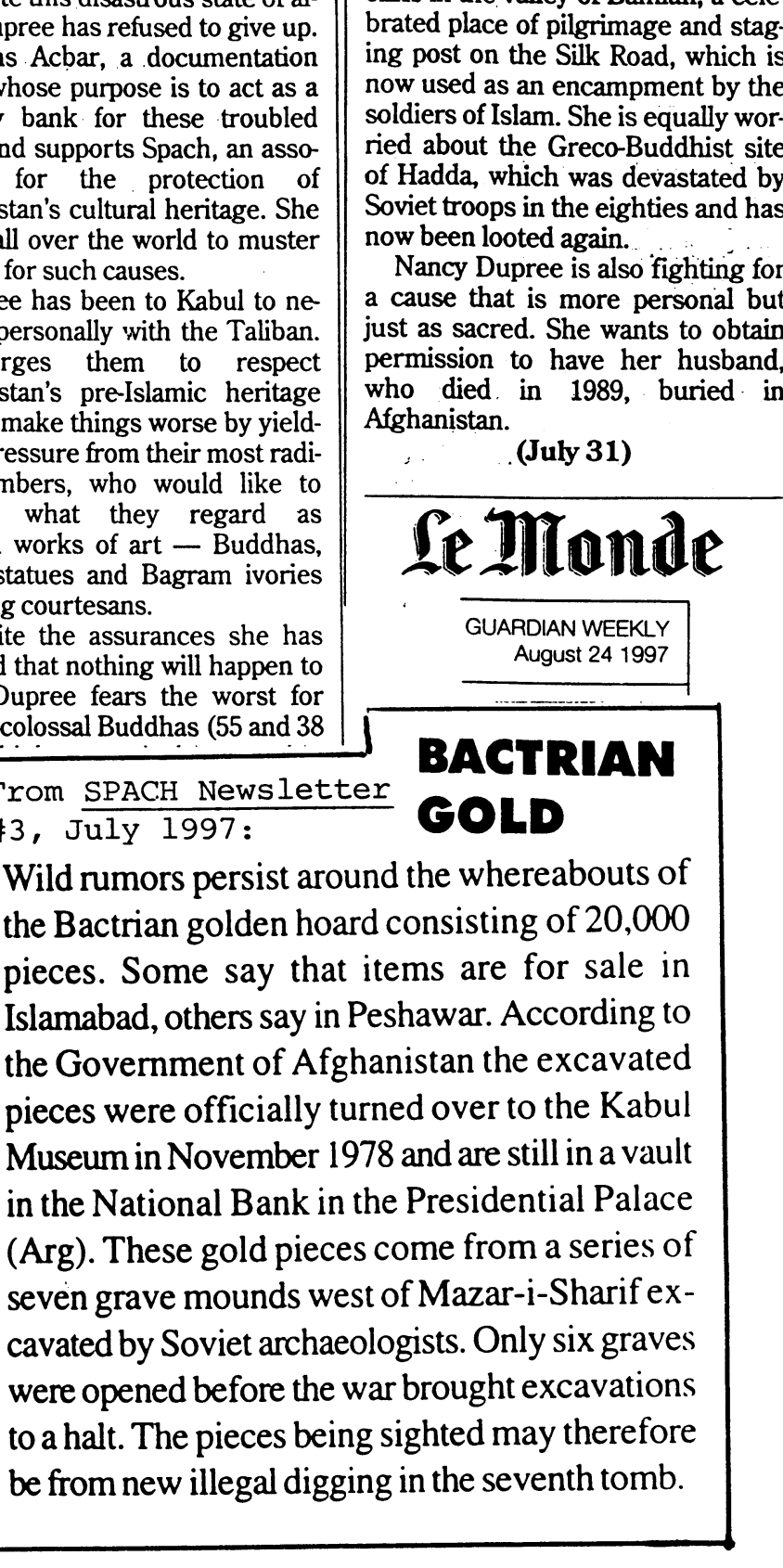

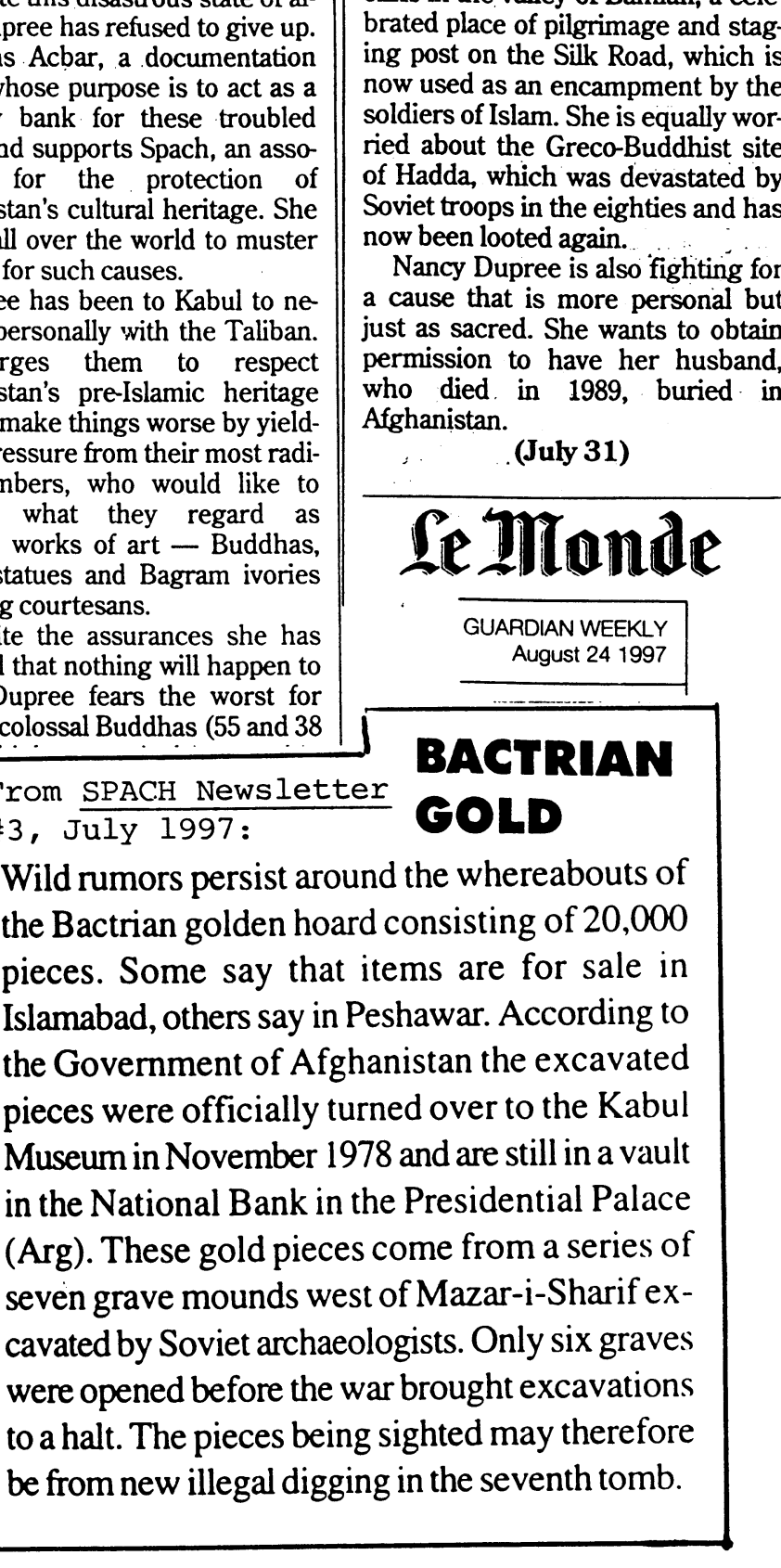

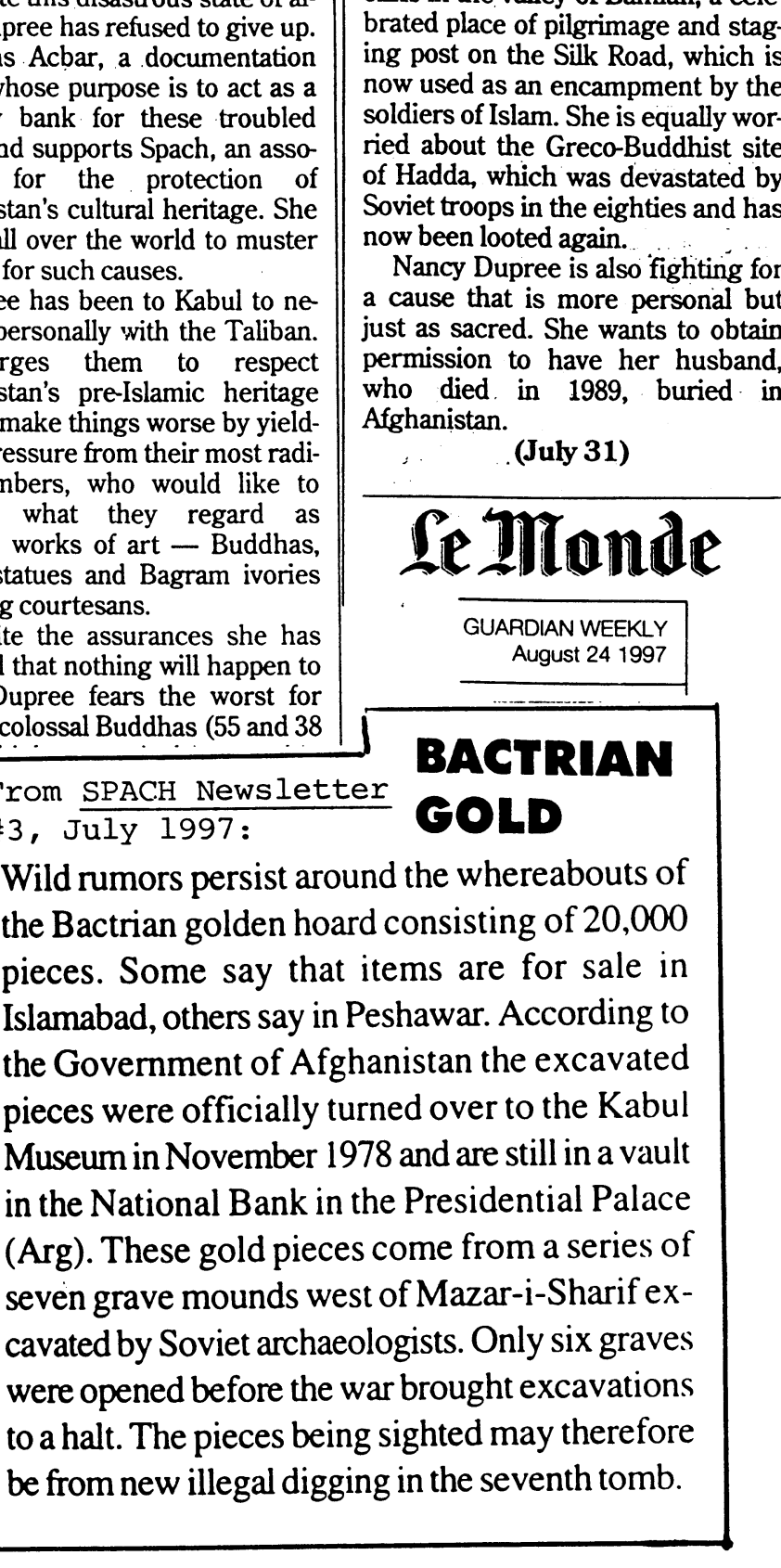

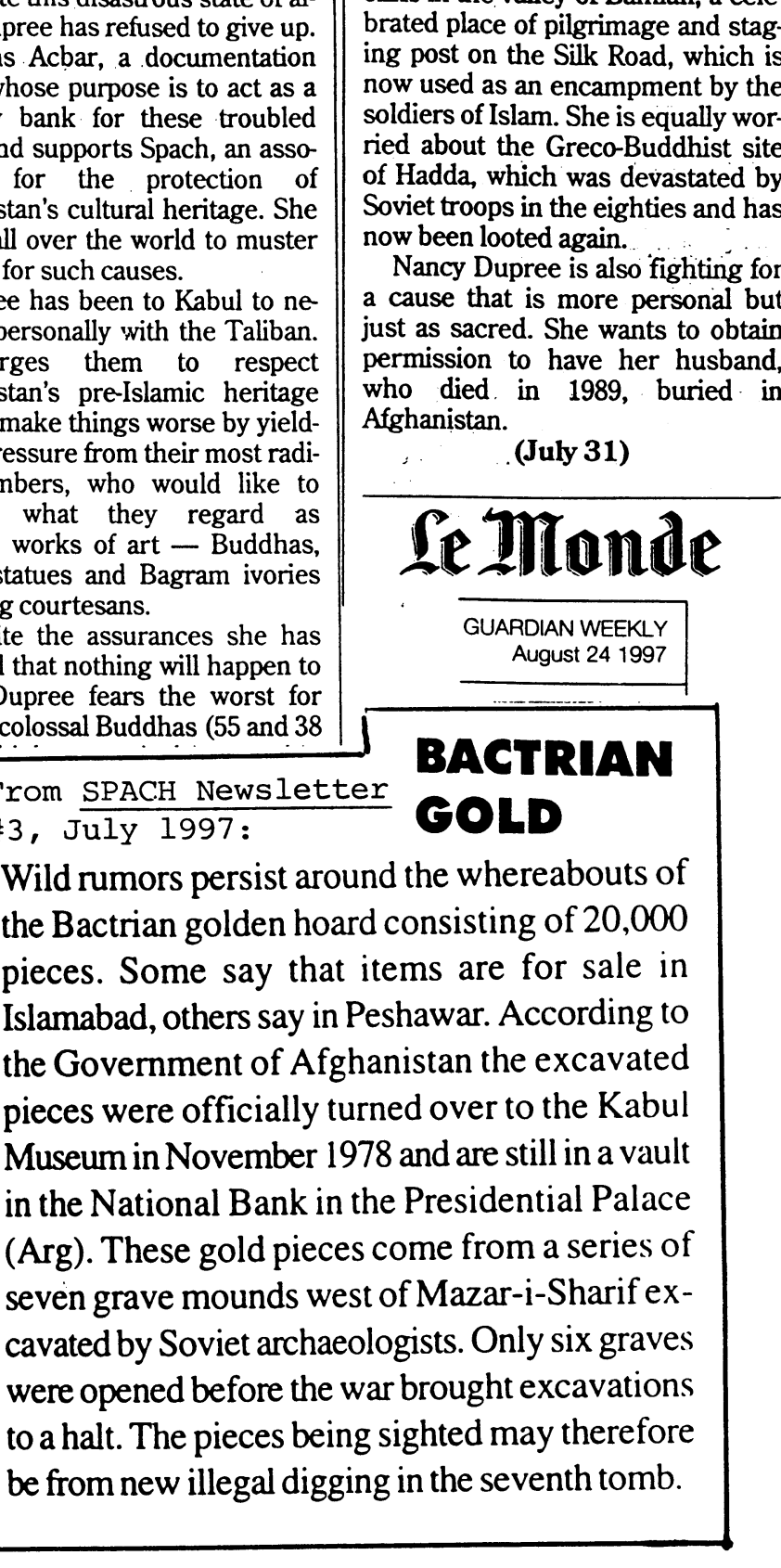

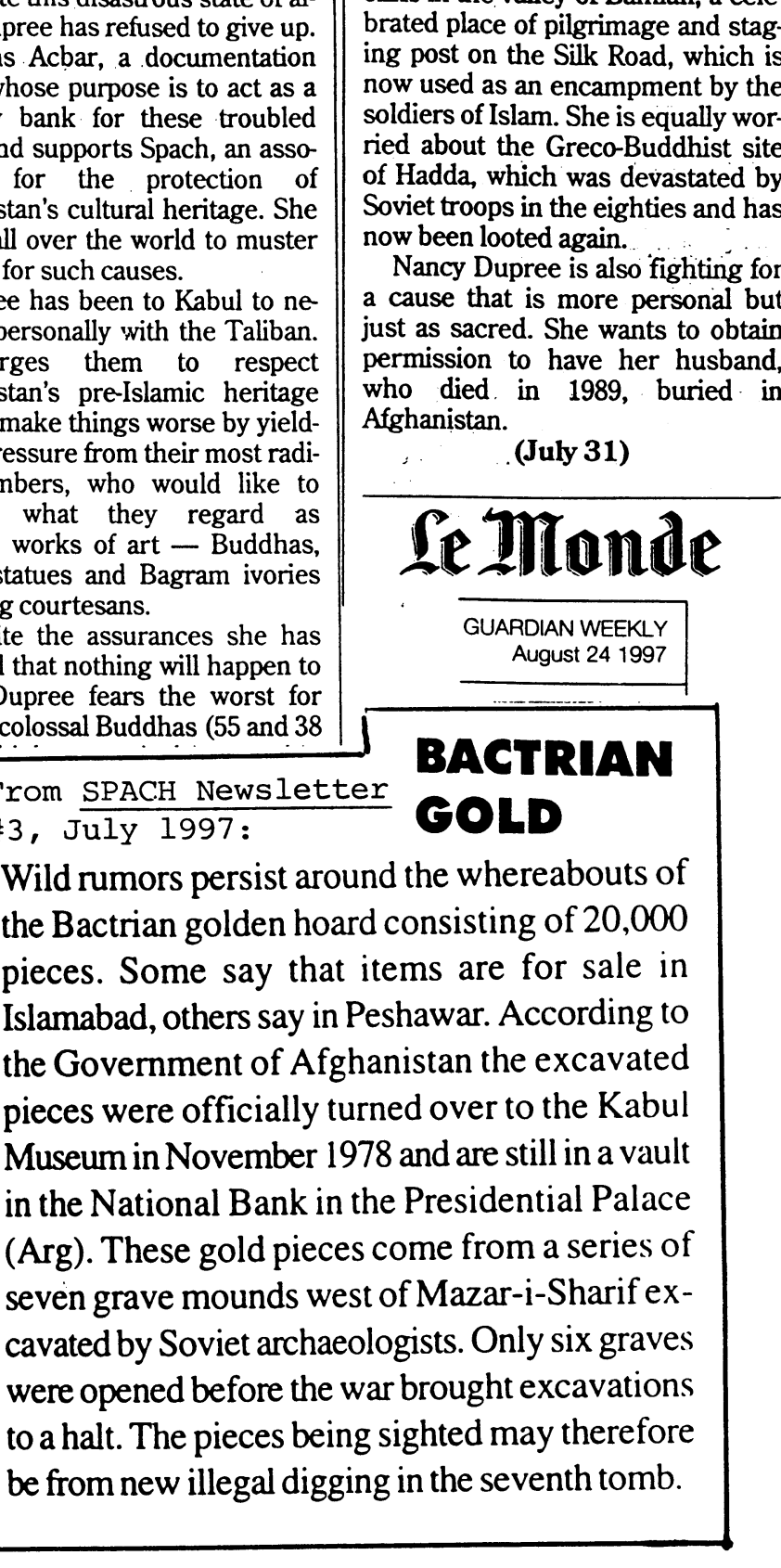

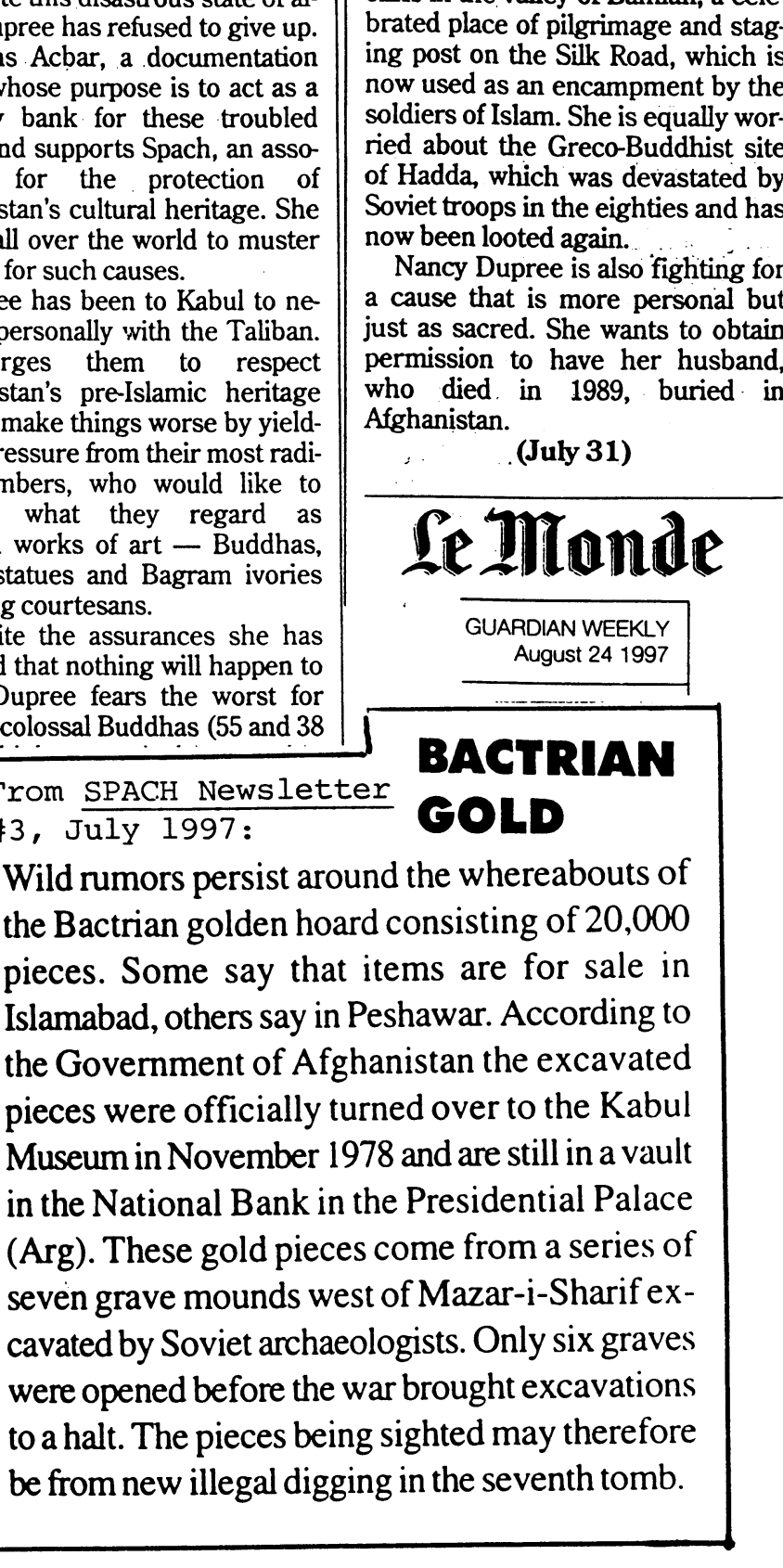

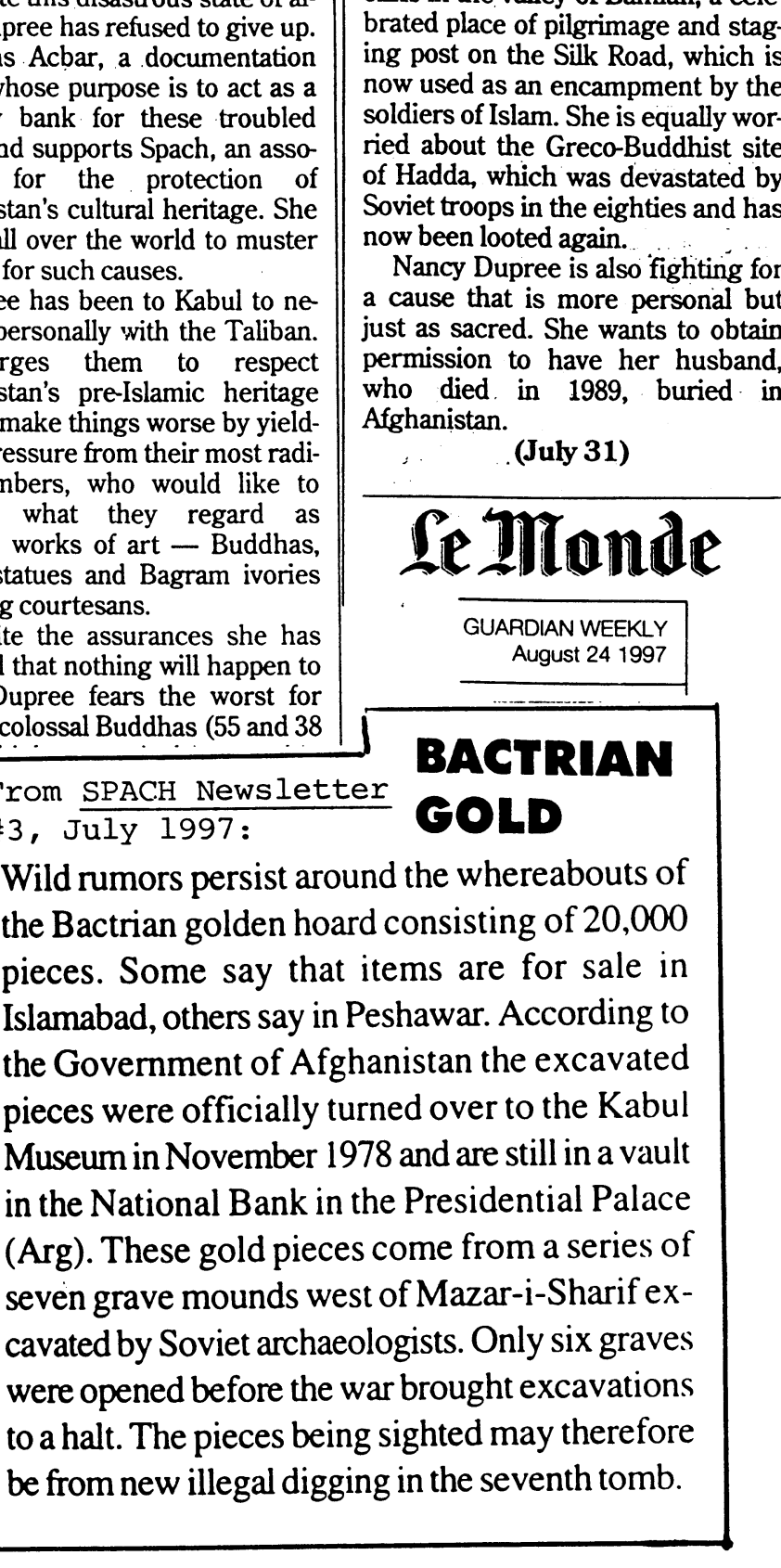

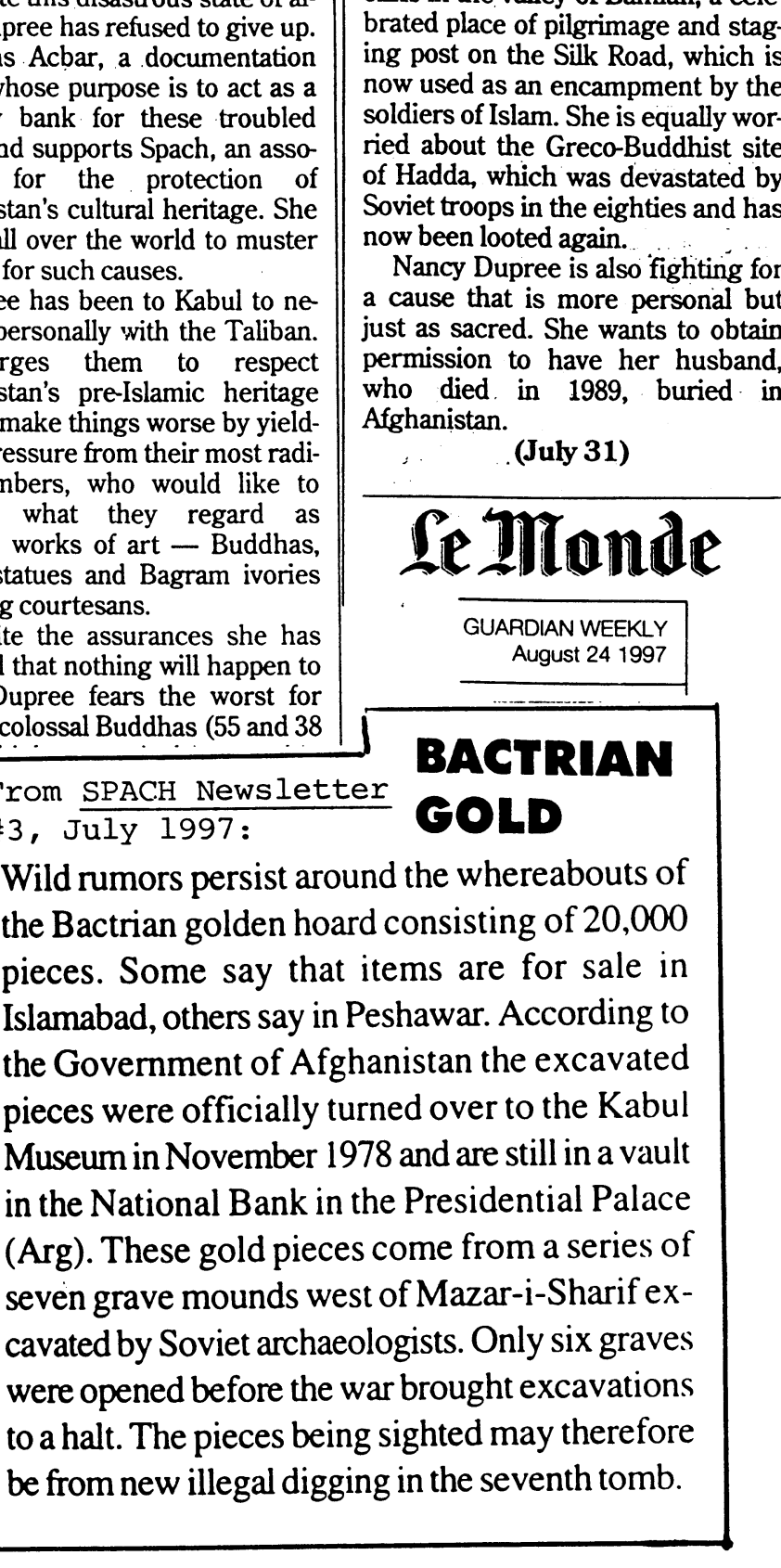

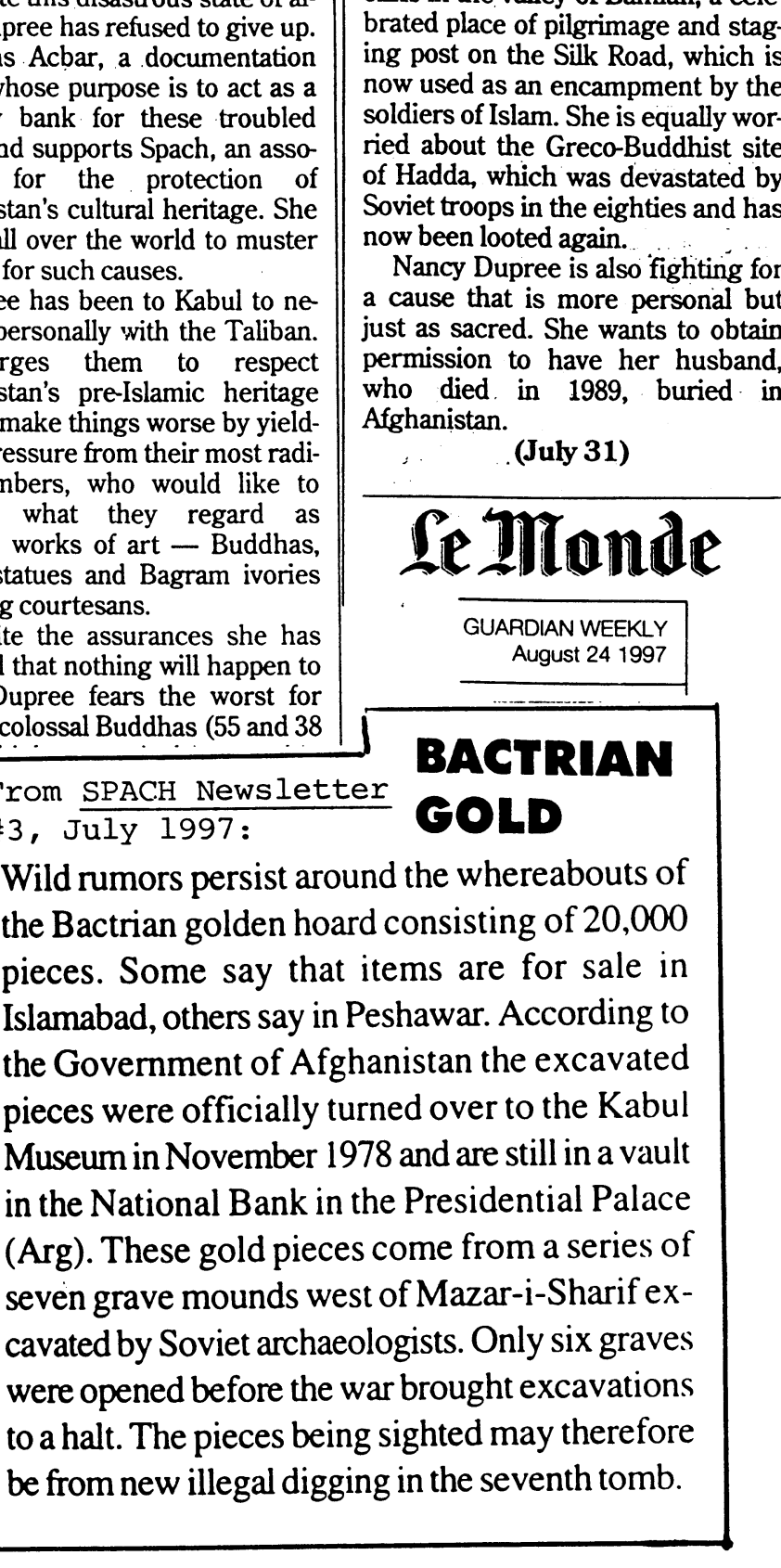

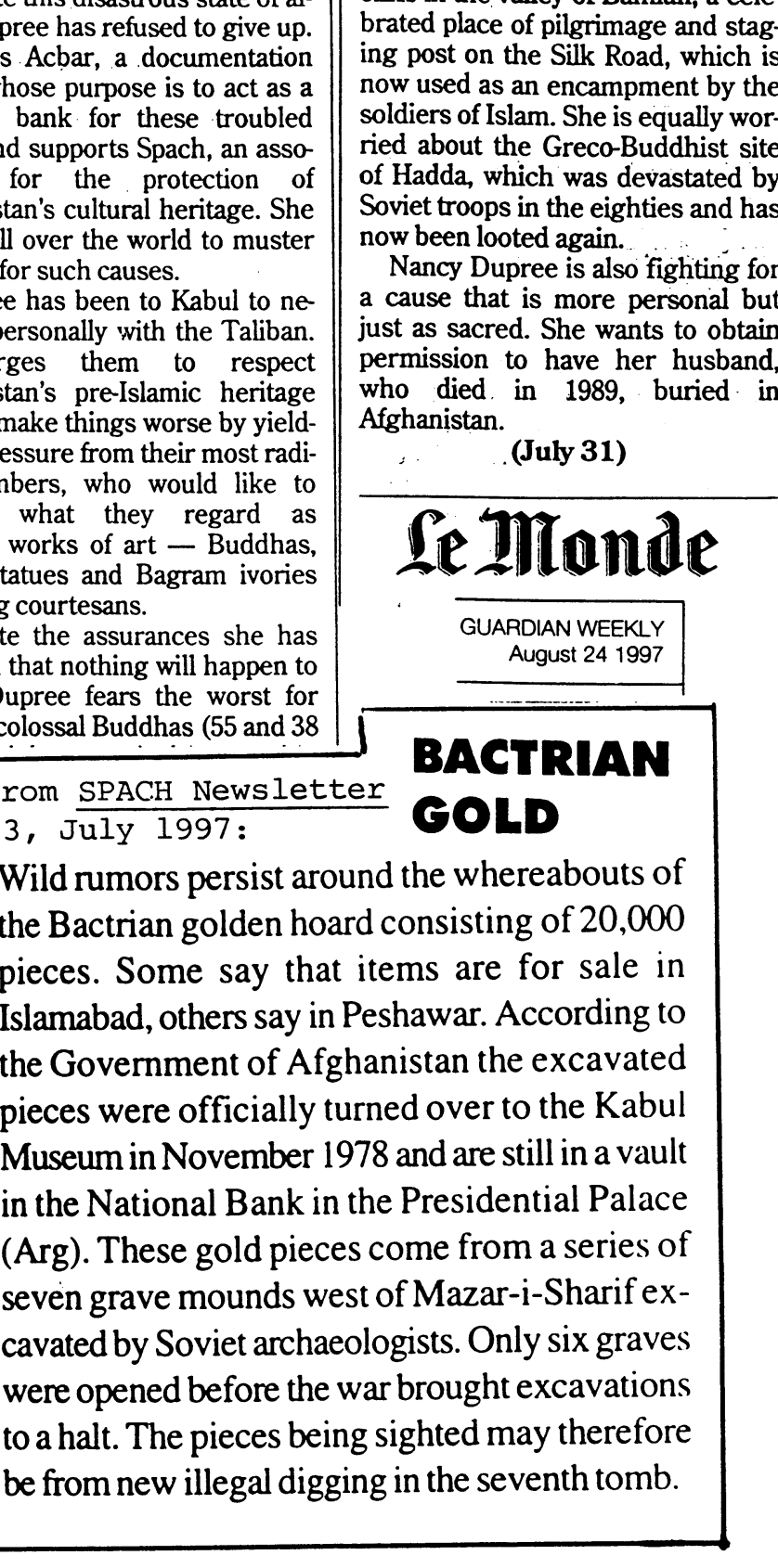

\footnotetext{
Herat has been listed on WORLD MONUMENT WATCH's 1997-1998 list of the "100 Most Endangered Sites." Annette Ittiq of the University of Toronto nominated the site; the sponsoring institution is the PostWar Reconstruction \& Development Unit, University of York, England. The unit has applied for funding for a cultural heritage conservation project for Herat from the WMW. For more information try http: //www . worldmonuments .org/heratf2 html.
} 


\section{THE KINGDOM OF AFGHANISTAN AND THE UNITED STATES, 1828 - 1973.}

By Leon B. Poullada and Leila D. J. Poullada. Omaha: Center for Afghanistan Studies at the University of Nebraska Omaha \& Dageford Publishing, 1995. 244 pp. Illus., maps, appendices, bibliography, index.

The death of Dr. Leon Poullada in 1987 was a great loss not only to his many friends and admirers and to Afghan studies in particular, but to policy makers with international concerns, and to a broad understanding of the significance of developments in Southwest and Central Asia and the Indian subcontinent, future as well as past and present.

Ambassador Poullada was America's finest scholar of the geopolitical history and significance of modern Afghanistan. He uniquely combined scholarship and meticulous and objective research with political savvy, a sophisticated analytical mind, years of political and diplomatic experience in Afghanistan, the region, and the Department of State, and a passionate concern for both the best interests of his own country and the future of the Afghan people.

Above all, he was imbued with an intellectual integrity that often led him to considered conclusions that differed greatly from official views and received opinion and might be unwelcome in influential circles - and, on the basis of those conclusions, to outspoken criticism of policies and policy-makers he believed to be obtuse, shallow and wrong-headed. But although some might disagree with his judgments, one could never doubt the rigor and seriousness with which he had reached them.

This book, designed to be an in-depth study of the entire spectrum of U. S. - Afghan relations, would undoubtedly have been his magnum opus, summing up a lifetime of thought and experience. Begun in the early 1970 s, it was reorganized after 1979 to include Afghanistan's emergence as a fulcrum of the struggle for political and economic power in South and Central Asia in our time, a struggle central to the concerns of everyone who is (or, as Leon often noted, should be) concerned with it. It is all the more unfortunate, therefore, that he died before he could write the chapters assessing developments in that tormented land since 1973. Leila Poullada, his wife and colleague, has not attempted to complete it for him, but has published the draft manuscript he had completed, adding his book outline and other useful appendices that indicate the direction of his thinking on these matters.

Even in its truncated form this book constitutes a formidable contribution to area studies - and to many related issues of U.S. foreign policy. In combination with his other writings in the 1980 s dealing with the Communist takeover, the Soviet invasion, and subsequent developments, it constitutes the single most important analysis to date of what he describes here and elsewhere as a longterm failure of American policy, which he views as an important factor contributing to that tragedy. Indeed, it is one of the few works to make a significant permanent contribution to our understanding of those events.

He reviews the history of repeated Afghan efforts from 1921 on to strengthen its ties with the United States, and of the repeated rejection and, all too often, the humiliating dismissal of those efforts. Some of the story is familiar, but he provides hitherto unpublished information and fresh insights, drops a few bombshells, opens important new avenues for future scholars to pursue, and, insofar as U. S. policy has not undergone informed rethinking, offers an implicit warning for the future.

Poullada begins at the beginning with the redoubtable Josiah Harlan and glances briefly at the handful of Americans who ventured into Afghanistan before the early 1930s. He then astutely identifies the often-overlooked influence of literature and sensational journalism in establishing and perpetuating Afghanistan's international image as a remote, self-isolating "hermit kingdom," populated entirely by fierce, lawless, brutish, half-savage, violently xenophobic religious fanatics. First of course there were British writers, above all Kipling 1 , and the famous signboard "absolutely" forbidding entry to Afghanistan, actually British but commonly believed to be evidence of Afghan hostility.

Starting in the 1920 s, sensationalized articles in National Geographic and the popular press reinforced that image. In 1925 the hugely popular travel writer Lowell Thomas - who had rocketed to fame by "discovering" T. E. Lawrence and dubbing him "Lawrence of Arabia" and was making a career of adventures in exotic places visited Kabul. His book Beyond Khyber Pass Into Forbidden Afghanistan was designed to promote his image as an intrepid reporter who risked life and limb for a scoop. That called for hair-raising peril and adventure, of which his trip apparently contained little, so he embellished it with melodramatic purple prose. Kabul became a "city of suspicion," and, despite courteous, cultivated hosts who spoke French and played tennis, the Afghans were characterized as "desperados... brigands... [who] obey neither God nor man. Their only law is the law of the rifle and the

1 Kipling, incidentally, never saw Afghanistan or the Khyber Pass, with which he is indelibly identified. He lived in Lahore and only once got as far as Rawalpindi, where as a young reporter he spent a few days covering the 1885 meeting between the Viceroy, Lord Dufferin, and the Amir Abdur Rahman. His knowledge of Afghanistan came from gossip he picked up in the bazaars and the barracks and officers' clubs of Lahore, but his brilliance as a writer enabled him to fix his image of the Afghans in the world's imagination. 
knife... more savage than the Mongol bandits." A best seller, the book permanently fixed that unsavory image in the minds of the American public and, Poullada suggests, apparently also among a handful Washington officials who for many years used it to justify their opposition to opening and upgrading U.S. - Afghan relations. ${ }^{2}$

He then gets down to the core of his study: a close analysis of formal relations between the two countries, which began in 1921 with the first approaches to Washington by an Afghanistan newly in charge of its own foreign relations. The story emerges as, for the most part, a series of what the Afghans, who had expected a friendly reception, increasingly (and often accurately) saw as bewildering and of ten humiliating rebuffs, a series of lost opportunities that might have affected the course of events decades later. He broadly attributes much of this to cultural differences that led to repeated misunderstandings, a combination of what he calls American misperceptions - Washington's mistaken view of Afghan realities - and Afghan misconceptions - their misinterpretations of American realities. He perceptively notes that while Americans prize directness and forthrightness in negotiations, in Afghan culture one does not make a request unless one is certain that it will be granted, lest both parties be embarrassed by a rejection. Over the years, therefore, the Afghans consistently initiated their approaches obliquely and indirectly, often trying to sound out the American response in advance through intermediaries. Some American officials used this as an excuse to reject them, while others failed to recognize that an approach was being made. 3

But a less diffuse and circumstantial picture emerges as he throws a spotlight on the little-known figure of Wallace Murray, head of the Division of Near Eastern Affairs in the U. S. State Department from the mid-1920s to at least the mid-1940s (and possibly later; the precise dates of his tenure are not given).

Poullada persuasively demonstrates that for at least two decades, Murray consistently used his position to block all Afghan efforts to gain recognition and establish full diplomatic relations, ignoring the strong recommendations of Cornelius Van H. Engert (whose efforts can be termed heroic), other American diplomats, American businessmen who saw Afghanistan's economic potential, and even members of Congress. Only a presidential order forced him to grant minimal recognition in 1933 - but thereafter he continued his efforts to impede and minimize relations of all kinds between the two countries at least until 1944 (if not beyond).

This is an important revelation. Murray's role and influence have not, to my knowledge, been examined in any major study. Among the standard histories, only Gregorian even mentions him - but takes at face value his objections to upgrading U. S. - Afghan relations.

Poullada doesn't speculate on the reasons for Murray's antagonism toward Afghanistan; he says they are "not clear." He recounts how, in the 1920 s and 1930s, American officials regularly consulted the views of the British Foreign Office, which was anxious to minimize independent Afghan action (as Afghans have suspected to be the case ever since). But one of Murray's official papers (quoted by Gregorian), which recommended against anything beyond a minimal American presence in Afghanistan "since the Afghans were unwilling to permit ... [American] missionary activity in their country," suggests the possibility of more obscure private reasons for his animus.

Poullada describes Murray as "a canny bureaucrat who had worked his way up," and it must have taken him some years to rise to his position. It is therefore possible that his attitude toward Afghanistan was influential as early as 1921, when the first Afghan diplomatic mission to Washington received a chilly reception and an official runaround, and in the rejection of Amanullah's proposed visit in 1928. Moreover, during his two decades or more in charge of Near Eastern affairs, he must surely have influenced many of his associates, not least through his policy papers (some of which read like excerpts from the Lowell Thomas book). Many of those men would have remained in influential positions long after his own retirement.Murray's influence may therefore have percolated through State Department offices and influenced policy for many years, perhaps even down to the official who told the Los Angeles Times in 1988, "Once the Soviet [troops] are out, Afghanistan is zeroesville."

It would be impossible to discuss all of Poullada's significant data and his fresh and astute insights in the compass of this review. For the World War II years, during which U. S.- Afghan relations began to move toward the close ties and warm friendship Kabul had long sought, much more information was available to him: he reviews Axis activities in Kabul, the awakening of America's strategic interest, and the policy differences between those who recognized that interest and those like Murray still reluctant to do so. He then plunges into the crucial

\footnotetext{
2 He errs, however, in stating that Thomas never mentions Amanullah or his reforms; the book includes photos of Thomas with Amanullah, who entertained him in Paghman and is described at some length - but, typical of Thomas's sensational prose, is pictured as an "enigma," "a democratic despot," inexplicable in his attempt to open his ferocious nation to the world. Thomas's portrait of Afghanistan is, of course, currently reinforced by the Taliban, who are generally viewed as more characteristic than aberrant.
}

3 It may be worth noting that, in this writer's experience, even in their most desperate hour of need following the Soviet invasion, many Afghans remained wedded to this modus operandi, unwilling to make direct requests or suggestions even when U.S. officials invited them. 
post-war period, when that burgeoning friendship was dissipated through a combination of misunderstandings, policy errors and, above all, the Pushtunistan issue (to which he devotes two chapters). His writing is dense with information, some of it new, and insight, much of it gleaned from his own experience, observation and involvement.

He does not absolve the Afghans entirely (although he may underestimate Daoud's rage and scorn for America and touches only lightly on the sometimes irrational intensity of the passions aroused by the Pushtunistan issue). Nevertheless he assigns most of the responsibility for the disastrous decline in relations to wrongheaded American policies - the result of ignorance, lack of understanding, narrowness of vision, and a return to the dismissive indifference that characterized Washington's pre-war (one might say Murray-esque) view of Afghanistan. He discusses the roles of various individuals in both governments who, in his view, contributed to those flawed policies or struggled, usually in vain, to change them, throughout the 1950 s and $1960 \mathrm{~s}$.

As indicated by his outline (Appendix I), his analysis of the period from World War II to the Soviet-Afghan War was to have formed the bulk of the book. Unfortunately, he had drafted only six of a projected fifteen chapters on this period when illness intervened, and although these form more than half of the present book, they are only about one-third of what he intended to write.

Fortunately, however, he did write elsewhere, even if at less length, about the catastrophic events that have overtaken Afghanistan since 1973 and 1978. His extended essay "The Road to Crisis, 1919-1980"4 can almost be read as an additional chapter of this book. Writing in the last year of his life, he abandoned diplomatic restraint to characterize continuing American diplomatic policy re Afghanistan as "ignorance, apathy, vacillation, pusilanimity, incoherence, marked by inconstancy and appeasement... timorous [and] rhetorical," marshalling facts and analysis to support his outrage. One can only speculate on what he would have to say about U. S. policy since his death: support for a settlement that left Soviet proxies in power and gave Moscow a free hand and, since then, the apparent loss of all but cosmetic interest in Afghanistan and its consequent abandonment to chaos and the machinations of its neighbors.

Leila Poullada has done an admirable job of preparing the manuscript for publication, providing notes, a bibliography, and nearly a dozen useful appendices, including one explaining the use of research resources in the National Archives. Leon was a polished writer, and the few minor errors are substantively insignificant, the sort of slips any author makes in a first draft; he would undoubtedly have caught and corrected them in the course of revising and editing; they may in fact be typos, but in any case they do not affect his argument.

As a first draft, the book is at times summary or sketchy. It is thematically organized, and presumably Leon's primary concern was to get down on paper the organizational structure and key points of his thinking. Had he lived to complete and revise it, he might well have expanded on a number of points and fleshed them out with fuller detail (e.g., Vice President Nixon's 1953 visit to Kabul), some of which appears in his other writings.

Even in its truncated form, however, this book is a tremendous contribution to area studies and to many related issues of U.S. foreign policy. (Insofar as some of the shortcomings of U. S. dealings with Afghanistan apply to relations with other countries, it has wider ramifications as well.) In combination with his other writings on the subject, it forms the single most important analysis of U. S. policy and its implications for the Communist takeover, the Soviet invasion, and subsequent developments.

It is one of the few works to make a significant permanent contribution to our understanding of that complex history. He has thrown light on much hitherto shadowed terrain. 5 Perhaps no one but Leon Poullada had the particular combination of qualifications, insight, experience, and determination to do so.

Henceforth, no serious scholar can discuss the modern history of Afghanistan and the region, including the subcontinent - or, for that matter, relevant U. S. Cold War and post-Cold War policies - without reference to Poullada's work, and specifically to this book. It is essential reading not only for specialists and anyone else interested in Afghanistan and the region, but for all students of modern American foreign policy and diplomacy. It belongs in every college library. Brief and incomplete though the book may be, its contribution is monumental.

- Rosanne Klass

New York, N. Y.

\footnotetext{
4 In Afghanistan - The Great Game Revisited (Freedom House/ University Press of America, 1987; rev. ed., 1990 ), $37-69$. This is an expansion of his essay "The Failure of American Diplomacy in Afghanistan" in World Affairs, Vol. 145, No. 3, Winter $1982-1983$. Both, edited by this reviewer. A list of his writings (though not, apparently, a complete one) is included in the bibliography.
}

5 Offering many opportunities for further research. 
OUT OF AFGHANISTAN: THE INSIDE STORY OF THE SOVIET WITHDRAWAL. By Diego Cordovez and Selig Harrison. Oxford University Press, 1995. 450 pp. Illus., map, appendix, index.

As UN Undersecretary-General for Special Political Affairs, Diego Cordovez negotiated the 1988 settlement, guaranteed by the United States, which left Moscow a free hand in Afghanistan and thereby contributed to the chaos that has followed. Selig Harrison, one of a tiny handful of western journalists repeatedly welcomed to Kabul after the Soviet invasion (he reported that Babrak Karmal was able and popular, and scotched the rumor that Babrak was a KGB agent), promoted those negotiations and called for international acceptance of permanent Soviet involvement in Afghanistan and a "broad-based" communist-controlled regime.

Though presented as a comprehensive factual historical record, their book is disingenuous and self-serving, designed to portray Cordovez as a diplomatic hero who merited his nomination for the Nobel Peace Prize, and Harrison as a reliable and farsighted analyst. (Here as elsewhere, Harrison blandly reverses and even denies some of his own past published statements.) It is neither impartial, objective nor complete. The authors apparently assume, probably correctly, that few readers have the special knowledge to question their version of events.

They do offer much previously unpublished behind-the-scenes detail, but it is highly selective - and more important than what they add is what they omit, conceal and distort. The book is, in short, a stacked deck - an attempt to set in concrete a picture of the Geneva Accords as a diplomatic triumph, achieved primarily by Cordovez's dedicated Herculean efforts (with Harrison as a prescient "inside" observer).

Evidence to the contrary is excluded. One would not know that there were grounds for serious, principled opposition to either the conduct of the negotiations or their results. Critics like Senator Gordon J. Humphrey, former UN Ambassador Jeane J. Kirkpatrick, and largely unnamed "others" [and, for the record, this reviewer] are dismissed as "ideologues," "hard right," and "bleeders" (whose motive, they assert, was only to punish the Russians in revenge for America's humiliation in Vietnam), or are shown as loose cannons. The authors minimize years of considered bipartisan opposition in the Congress, the NSC, several cabinet-level departments and other responsible quarters to U. S. agreement to what were correctly suspected to be the settlement's one-sided terms. The rigid exclusion of all Afghans except the Kabul regimes from the negotiations goes unquestioned indeed, almost unmentioned - while the views of Resistance and other anti-communist Afghan leaders are effectively ignored.

The book provides an almost overwhelming mass of detail - but what can be trusted and what cannot? Many ostensible "facts" are actually merely claims, interpretations or even disinformation (some of it of Soviet origin), often inextricably entangled with genuine fact. Much cannot be independently verified; some can actually be disproven or at the least viewed in a very different light. Even more significant are the many omissions: some of these are obvious (e.g., there is no mention of the resolution passed unanimously by the U. S. Senate which briefly came close to derailing the signing; President Zia's death is mentioned only in passing and described as "mysterious" and "still unexplained," which is simply not true) and there are indications of other omissions less easily recognized. There may well be still others invisible except to interested parties who were actively involved.

Some of the authors' revelations make it obvious, perhaps inadvertently, why the negotiations and the terms of the settlement and U.S. commitments were kept a closely guarded secret until after the ink was dry on the accords - denied even (or perhaps especially) to members of the Senate Foreign Relations Committee, despite their repeated requests, until late on the night before the signing. As one former U. S. official who was deeply involved in the issue remarked after reading the book, "Just on the basis of what they admit, what was really going on was worse than our worst suspicions."

Thanks to the veil of secrecy that still shrouds these events, ill-informed or sympathetic reviewers have uncritically hailed the book as definitive. It does have its uses: for those who were privy in any degree to the political battle over the settlement, who can approach it with informed skepticism and spot at least some of the omissions and distortions, it illuminates certain aspects of the still-hidden extent and nature of the political manipulations involved. For example, the authors confirm quite casually the long-standing suspicion that President Reagan's policy of steadfast support for the Afghan cause was reversed by U.S. officials without his knowledge in their eyes, a wise step (though one still not admitted in Washington).

Even those who followed events closely from outside will recognize some of the more obvious biases (e.g., despite massive evidence to the contrary, some of it from post-Soviet Russian sources, Harrison recounts as fact the explanation of the invasion that Moscow finally settled on after several false starts with other stories: that it was a "mistake" into which Soviet leaders inadvertently "stumbled").

But less knowledgeable readers should approach this book with the same caution they would bring to any other memoir by a political figure anxious to assure for himself history's laurels, and any account by a political writer seeking to validate his claim to punditry.

$$
\text { - R. K. }
$$


A TRIBUTE TO LEON POULLADA, founder of the Afghanistan Council NEWSLETTER, which later became the AFGHANISTAN FORUM.

By Nake M. Kamrany, Dept. of Economics, Univ. of Southern California.

A common thread among the three most prominent American scholars on Afghanistan, Louis Dupree, Arnold Fletcher \& Leon Poullada, was their love for the country \& people of Afghanistan. Leon Poullada, a diplomat turned scholar, contributed enormously to the literature of the political economy of Afghanistan, \& to the institutional development of Afghan studies.

Poullada's seminal first work, his dissertation at Princeton, was subsequently published by Cornell University Press in 1973. REFORM \& REBELLION IN AFGHANISTAN developed an elegant theory of the relationship between the center \& the periphery in maintaining political stability or instability in Afghanistan. Alas, every successor to Amanullah has failed to either modernize and/or stabilize the country .

Poullada's last book, THE KINGDOM OF AFGHANISTAN \& THE UNITED STATES 1828-1973 (reviewed on p. 38), documented the US Gov't's black spots in not comprehending \& understanding Afghanistan from the inception of Afghan-US diplomatic relations.

Leon published more than 20 books and articles on Afghanistan \& was held in high esteem by students of Afghan studies. He was the first elected president of the Association of Afghanistan Studies (1974), \& was in demand as panelist, speaker, conference organizer, editor \& collaborator. Above all, he was keen to get Afghans involved in the development of these institutions.

Leon possessed warmth \& wit; integrity \& forthrightness. He inspired confidence. In addition to being a first rate scholar, Leon was a diplomat, a political scientist and an attorney. He had a working knowledge of 10 languages. He served as a Chief Counsel at the Nuremburg trials \& as a negotiator in the Indus River dispute between India \& Pakistan.

Leon is missed by all of us. Were he alive today, he would be working hard to find a solution to the current internal strife in Afghanistan. God bless his soul.
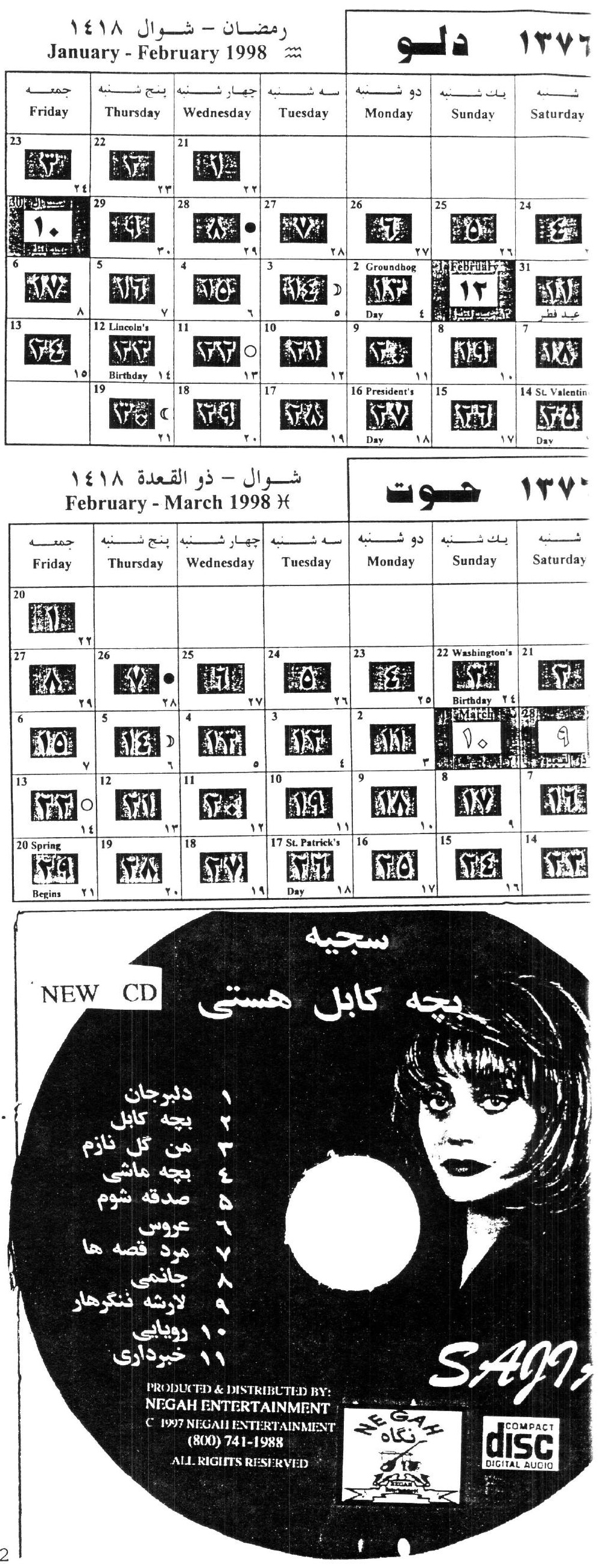
AT THE UN, A NEW VOICE STRESSES BALANCE IN APPROACHING HUMAN RIGHTS

Excerpts from an article by Barbara Crossette in the NYT, 10/6:

UNITED NATIONS, Oct. 3 - The Government leaders who flock to the United Nations every autumn to make speeches, drink toasts and dabble in back-room diplomacy found something new on their appointment calendars this year: human rights and Mary Robinson.

Mrs. Robinson, who resigned a largely ceremonial post as President of Ireland last month, has been the United Nations High Commissioner for Human Rights for barely three weeks, but she has already been busy: soothing China, upsetting Algeria, reacting calmly to Afghanistan and warning the Democratic Republic of Congo, the former Zaire.

"She is at ease with difficult issues and confident in dealing with them," said Stephanie Grant, program director at the Lawyers Committee for Human Rights.

Discussing the Taliban, the militant Islamic movement that has taken control of most of Afghanistan, Mrs. Robinson does not align herself with those demanding reduced United Nations assistance because of the Taliban's harsh treatment of women.

"I intend to try to get more informed Islamic legal thinking than I've had so far," she said. "I think the problem, particularly in Afghanistan, is that this is not a village culture growing up from the communities. Village cultures are in fact very accommodating of different viewpoints. This is young men being prepared to fight a fight, and part of that is their militant sense of the Islamic law.

\footnotetext{
"We're not going to make real progress for women in Afghanistan unless we can do it within their culture." she said.
}

\section{QDOS \& ENDS}

KABUL PLANNING TO LAUNCH REGULAR ARMY by Ahmad Hassan in DAWN via Afghan News 1/7/98:

Taliban has embarked on launching a nat'l army. Two army divisions \& 1 air force corps would be formed at first. For this, the Taliban have sought the services of former Afghan army officials.

Preference is being given to the ex-servicemen who were trained in other than communist states. Some former Afghan army officials have decided to return to Afghanistan to join the nat'l army. One general, Rahmatullah Safi, has arriven in Pakistan and plans to go to Kandahar to meet Taliban chief Mullah Omar.

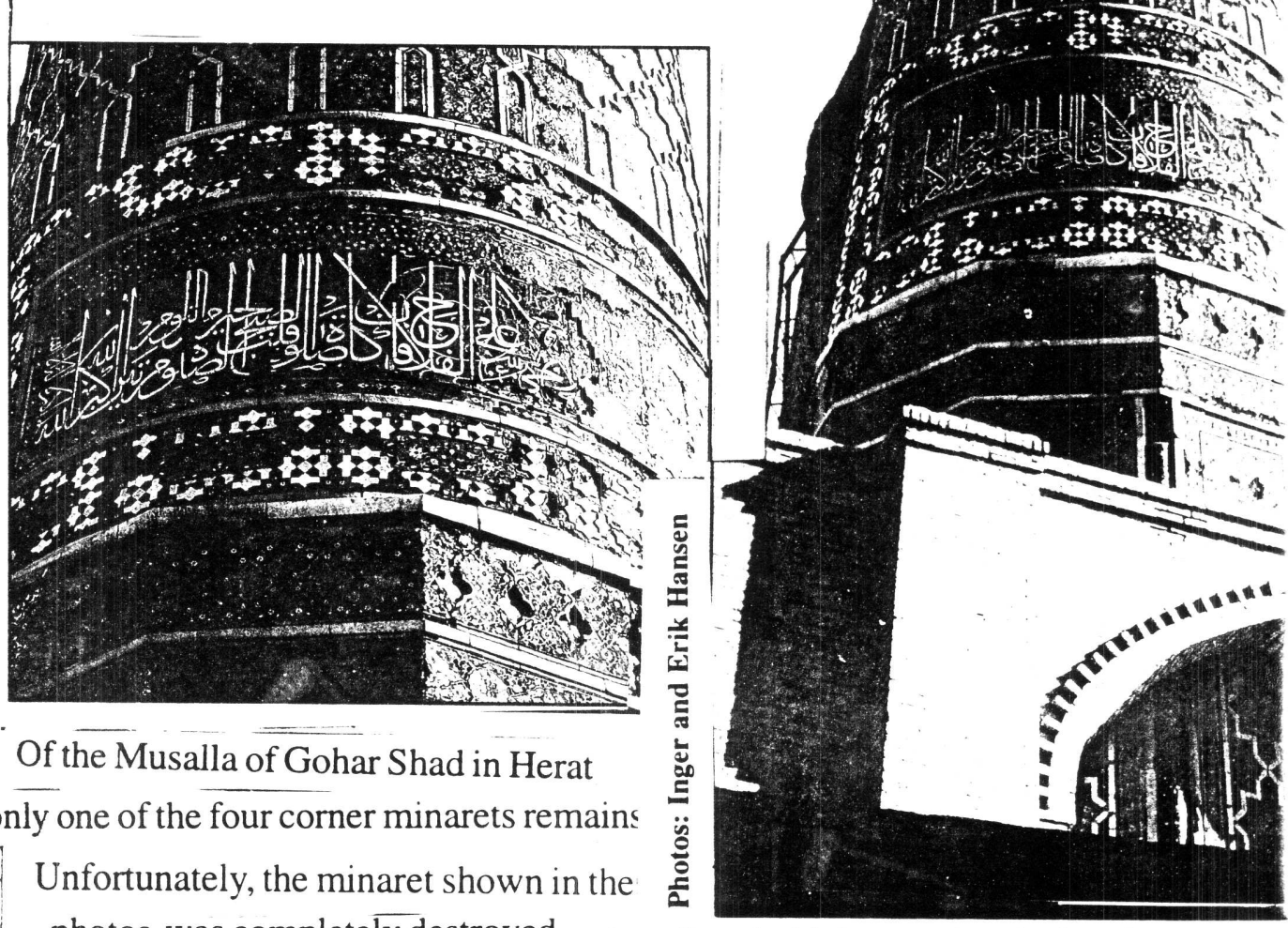

photos was completely destroyed, when directly hit by a rocket during the war.

\section{SPACH GREETING CARDS}

SPACH greeting cards with photographs of the large Bamiyan Buddha. Shrine of Khwaja Abdullah Ansari (Herat), Shrine of Hazrat Ali (Mazar-i-Sharif), Kabul Museum, Masjid-i-No Gumbad (Balkh), Shrine of Khwaja Parsa (Balkh) and Ghorid Portal/Friday Mosque (Herat) can be ordered from Brigitte Neubacher, UNOCHA. Islamabad. A pack of ten cards with envelopes costs Rs200 or US\$5. UNOCHA, POB 1809, Islamabad, Pakistan

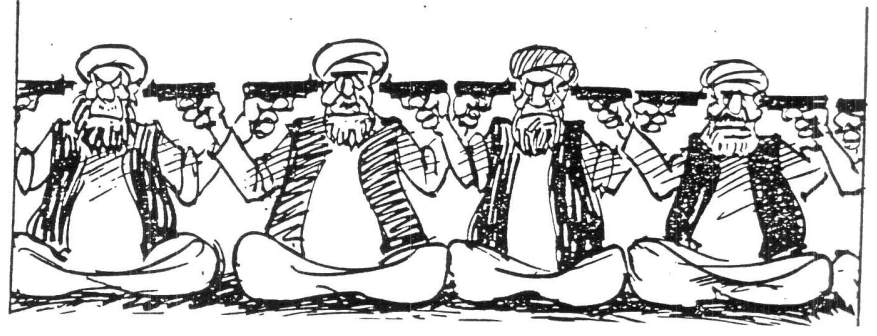


No News Is Good News!

Peace Be Upon You. 